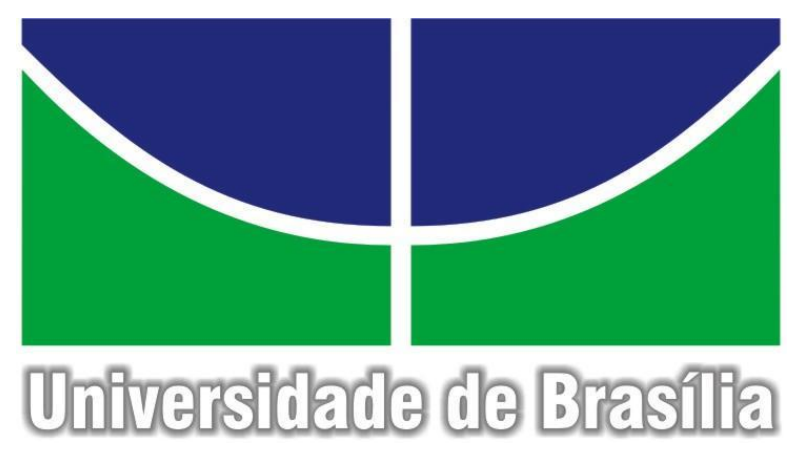

PROGRAMA DE PÓS-GRADUAÇÃO EM LINGUÍSTICA APLICADA - PGLA MESTRADO

FÁBIO HENRIQUE BARROZO

PRODUZIR PARA APRENDER:

A IMPORTÂNCIA DAS FERRAMENTAS DIGITAIS PARA A PRÁTICA DE ENSINO DE LÍNGUAS ESTRANGEIRAS

ORIENTADORA: Profa. Dra. Janaína Soares Alves

BRASÍLIA-DF 2016 



\section{FÁBIO HENRIQUE BARROZO}

PRODUZIR PARA APRENDER:

A IMPORTÂNCIA DAS FERRAMENTAS DIGITAIS PARA

\section{A PRÁTICA DE ENSINO DE LÍNGUAS ESTRANGEIRAS}

Dissertação apresentada ao Programa de Pós-Graduação em Linguística Aplicada da Universidade de Brasília (UnB), como requisito parcial para a obtenção do título de Mestre em Linguística Aplicada.

BRASÍLIA 
Barrozo, Fábio Henrique.

Produzir Para Aprender: A Importância das Ferramentas Digitais para a Prática de Ensino de Línguas Estrangeiras. Brasília/DF, 2016.

№ DE PÁGINAS: 149

Área de concentração: Linguística Aplicada

Orientadora: Prof ${ }^{a}$. Dra. Janaina Soares Alves

Dissertação de Mestrado - Programa de Pós-Graduação em Linguística Aplicada da Universidade de Brasília, Distrito Federal.

1. Ensino de Língua Estrangeira; 2. Ferramentas Digitais;

3. Atividades de Produção Audiovisual; 4. Competência Comunicativa;

5. Aquisição de Língua Estrangeira. 



\title{
FÁBIO HENRIQUE BARROZO
}

\section{PRODUZIR PARA APRENDER: A IMPORTÂNCIA DAS FERRAMENTAS DIGITAIS PARA A PRÁTICA DE ENSINO DE LÍNGUAS ESTRANGEIRAS}

\author{
Dissertação apresentada ao Programa de Pós- \\ Graduação em Linguística Aplicada da \\ Universidade de Brasilia (UnB), como requisito \\ parcial para a obtenção do título de Mestre em \\ Linguística Aplicada.
}

Aprovada pelos seguintes membros da Banca Examinadora:

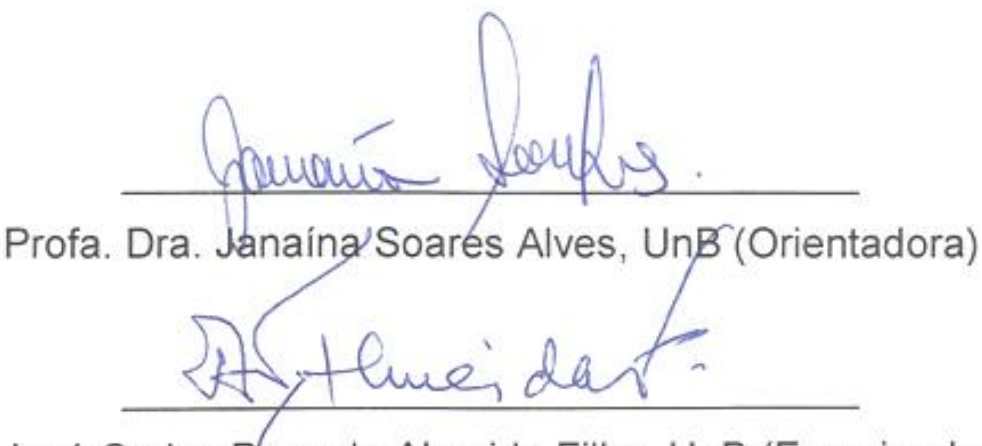

Prof. Dr. José Carlos Paes de Almeida Filho, UnB (Examinador Interno)

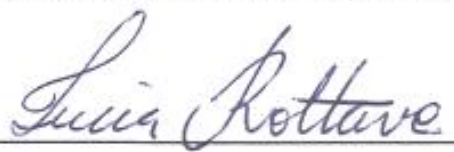

Profa. Dra. Lúcia Rottava, UFRGS (Examinadora Externa)

Profa. Dra. Maria del Carmen de la Torre Aranda, UnB (Examinadora Interna - Suplente) 
Aos meus professores, a toda a comunidade acadêmica e em especial aos professores dos Centros Interescolares de Línguas do Distrito Federal. Aos meus pais, João Barrozo e Maria Pereira. 


\section{AGRADECIMENTOS}

Agradeço primeiramente a Deus, à minha família e a todos os profissionais de educação que de forma direta ou indireta contribuíram para que eu persistisse na busca de melhor formação acadêmica e humana.

Ao professor Dr. José Carlos de Almeida Filho pelo exemplo profissional que nos tem sido desde a época de minha graduação na UnB.

Às professoras Dra. Janaína Soares e Dra. Carmen Aranda pelos valiosos direcionamentos ofertados a esta pesquisa.

À professora Dra. Lúcia Rottava por suas contribuições acadêmicas à Linguística Aplicada e por aceitar o convite para participar como examinadora externa desta pesquisa.

Aos meus colegas de pós-graduação: Ana Lúcia Alouche Busso, André Couto Santos, André Santana Machado, Camila Oliveira Macêdo, Eliana Barbosa dos Santos, Elizângela dos Santos Alves da Silva, Gizele Santos de Araujo, Glauco Wright da Silva, Helenice Aparecida de Oliveira, Ingrid Sinimbu Cruz, Jane Margareth Ferreira, Larisse Lázaro Santos Pinheiro, Lígia Soares Sene, Luana Mazarak Macedo, Lucas Henrique Garcia, Luiza de Fátima dos Santos Nucci, Poliana Alves Brito, Rafaella Kazue Gitirana Umetsu, Saori Nishihata, Sara Domingos de Sousa Araujo, Suellen Mayara Magalhães, Tábata Quintana Yonaha, Tatianne Gomes de Sousa, Walesca Afonso Alves Porto e Keni Carla da Silva Machado, pois fizeram parte da minha trajetória acadêmica e puderam contribuir de alguma forma ao meu crescimento tanto como pesquisador quanto como pessoa.

Aos professores Gerson Moura, Samara Cordeiro, Marisa Santos, Adriana Pires e Yuri pelas contribuições a esta pesquisa e aos demais professores e gestores do CILT e do CILC por tornarem fácil a circulação e coleta de registros nas escolas pesquisadas. 


\section{RESUMO}

Este trabalho investigou como algumas ferramentas digitais e atividades de produção audiovisual têm sido usadas por professores de línguas para fomentar um maior contato dos alunos com a língua alvo. Apresentou parâmetros e funcionalidades do uso dessas tecnologias no ensino de língua estrangeira (ELE), bem como experiências e resultados de seus usos em sala de aula, a partir do desenvolvimento de uma pesquisa sobre os seguintes eixos: a) aprofundamento teórico sobre a importância da produção oral e escrita nos meios modernos de comunicação para o desenvolvimento da competência comunicativa dos alunos; b) levantamento sobre quais ferramentas têm sido mais facilmente absorvidas pelos professores de língua estrangeira nos Centros Interescolares de Línguas do Distrito Federal e outras potencialmente relevantes para esse fim. Sabemos que o ensino de línguas no Brasil possui algumas características peculiares que o faz ainda mais dependente de estratégias didáticas capazes de oportunizar práticas comunicativas em níveis mais elevados quanto às vantagens que podem oferecer para estimular a aquisição de língua estrangeira entre os alunos. Logo, este estudo visou prover aos professores com considerações epistemológicas sobre competência comunicativa, aquisição de língua estrangeira e o valor didático de algumas atividades de produção audiovisual e suas ferramentas para o ELE. Foram realizadas múltiplas estratégias de coleta de registros que, após sua categorização, puderam ser tranformados em dados de pesquisa que, por sua vez, foram analizados segundo critérios e princípios que valorizaram tanto as vantagens didáticas atualmente observadas nos locais de pesquisa como as potencialmente relevantes para apoiar o ensino/aprendizagem de línguas. Enfim, culminou-se em considerações que defendem uma maior presença das ferramentas digitais no Ensino de Língua Estrangeira para, principalmente, auxiliar práticas de produção audiovisual que oportunizem o uso criativo da língua alvo e para fins diversos, desde o aperfeiçoamento da comunicação entre os participantes de cada atividade à promoção me maior autonomia entre os alunos.

\section{Palavras-chave:}

Atividades de Produção Audiovisual, Ferramentas Digitais, Competência Comunicativa, Aquisição de Língua Estrangeira, Ensino de Língua Estrangeira. 


\begin{abstract}
This work searched for ways in which some digital tools and audiovisual production tasks have been used by language teachers to stimulate students to seek a deeper contact with the target language and presents parameters and functionalities related to the use of such technologies for foreign or second language teaching, as well as experiences and results through its uses in classrooms, aiming to develop a research over the following axis: a) a theoretic deepening over the importance of written and oral output through modern means of communication to promote pupils' communicative competence; b) a survey of which tools have been more easily absorbed by language teachers in CIL (Interscholastic Language Centers) and others that can be powerful for this purpose. We know that language teaching in Brazil presents some peculiar features that make it still more dependent on didactic strategies that can propitiate communicative practices in higher levels in relation to the advantages it can bring to stimulate language acquisition among students. So, this study intends to provide teachers with epistemological considerations about communicative competence, foreign language acquisition and didactic values of some audiovisual production activities and its resources for language teaching. Multiple strategies of records collection were made so that it could be transformed into research data after its categorization. These data were analysed following some tenets and criterion that valued both the didactic advantages currently observed in the fields of research and the potentially relevant for language teaching and learning. Finally, it culminated in some considerations that defend a higher presence of the digital tools in language teaching in order to support audiovisual production practices that opportunize a creative use of the target language and for other purposes, from the improvement of the communication between participants of each activity to a grater autonomy promotion among them.
\end{abstract}

\title{
Keywords:
}

Audiovisual Production Activities, Digital Tools, Communicative Competence, Foreign Language Acquisition, Foreign Language Teaching. 


\section{LISTA DE ILUSTRAÇÕES}

FIGURA 1 - Modelo de competência comunicativa 27

FIGURA 2 - Metáfora do pêndulo 34

FIGURA 3 - Representação orbital das teorias 35

FIGURA 4 - Roteiro escrito 102

FIGURA 5 - Roteiro visual 102

FIGURA 6 - Amostra de produção usando a ferramenta storybird 


\section{LISTA DE QUADROS}

QUADRO 1 - Editores de vídeo online

QUADRO 2 - Sinopse do filme "el asesino del profe" 102

QUADRO 3 - Ferramentas para a produção de roteiros visuais 106

QUADRO 4 - Aplicativos para a produção de roteiros visuais 106

QUADRO 5 - Sites de apoio à produção teatral em espanhol

QUADRO 6 - Sites de apoio à produção teatral em inglês

QUADRO 7 - Sites de apoio à produção teatral em francês

QUADRO 8 - Ferramentas de livre experimentação musical

QUADRO 9 - Ferramentas de apoio à escrita criativa

QUADRO 10 - Ferramentas para a criação de histórias em quadrinhos

QUADRO 11 - Sites para aprender idiomas 
ALE - Aquisição de Língua Estrangeira

APA - Atividades de Produção Audiovisual

ASL - Aquisição de Segunda Língua

CC - Competência Comunicativa

CEMDF - Centros de Ensino Médio do Distrito Federal

CIL - Centros Interescolares de Línguas do Distrito Federal

CILC - Centro Interescolar de Línguas de Taguatinga

CILT - Centro Interescolar de Línguas de Ceilândia

ELE - Ensino de Língua Estrangeira

FD - Ferramentas Digitais

L1 - Língua Materna

L2 - Segunda Língua

LA - Linguística Aplicada

LE - Língua Estrangeira 


\section{SUMÁRIO}

1 INTRODUÇÃO

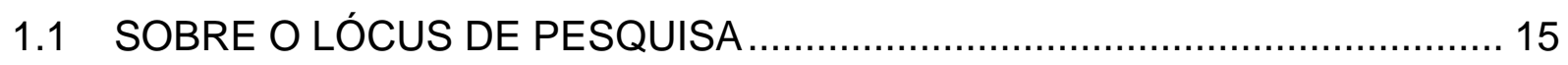

1.2 SOBRE OBJETIVOS E MODO DE APRESENTAÇÃO TEXTUAL .................. 18

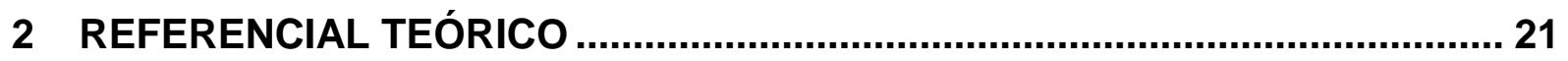

2.1 BENEFÍCIOS DA PRODUÇÃO AUDIOVISUAL PARA O ELE …..................... 21

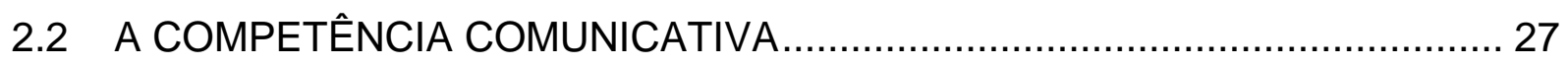

2.2.1 Subcompetências Linguística e Metalinguística ....................................... 30

2.2.2 Subcompetências Interacional e Discursivo-Textual ................................... 31

2.2.3 Subcompetências Estratégica, Formulaica e Lúdico-estética....................... 32

2.3 AQUISIÇÃO DE LÍNGUA ESTRANGEIRA …............................................. 33

2.3.1 A PERSPECTIVA DA COMPLEXIDADE ................................................ 34

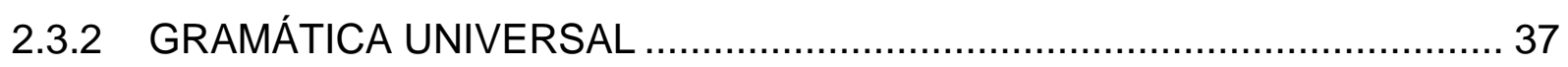

2.3.3 HIPÓTESE DA COMPREENSÃO....................................................... 40

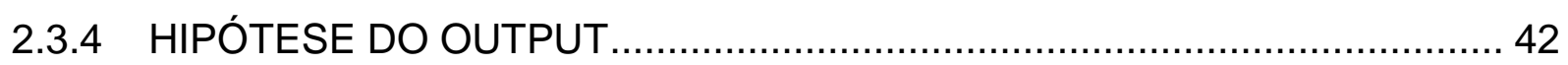

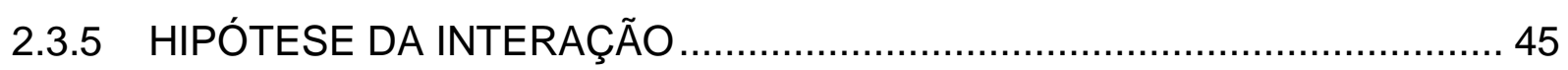

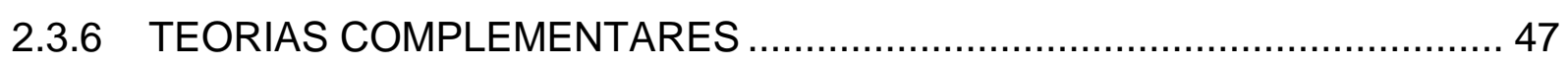

2.3.7 SOBRE A MAIS-VALIA DAS TEORIAS APRESENTADAS ....................... 50

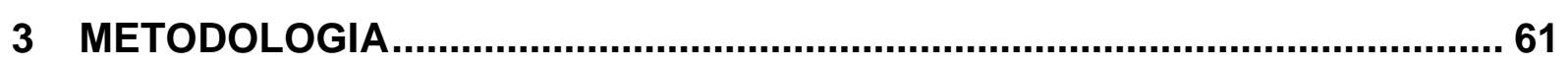

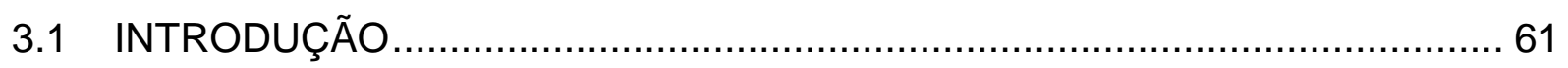

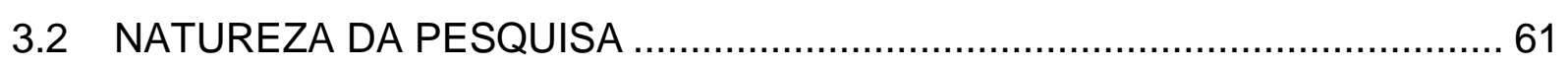

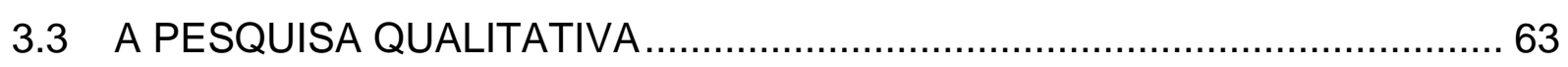

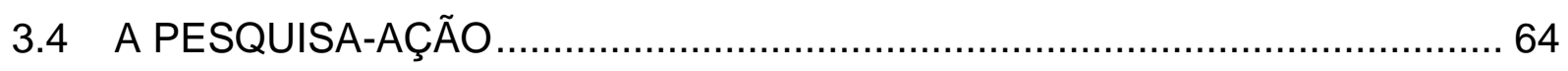

3.5 INSTRUMENTOS DE COLETA DE REGISTROS …...................................6 66

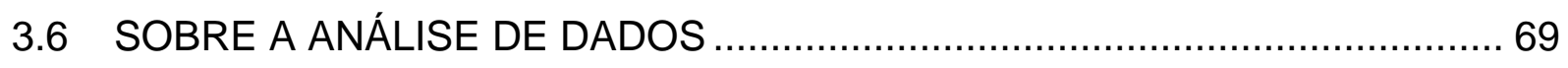

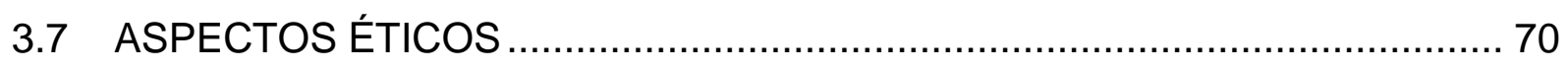

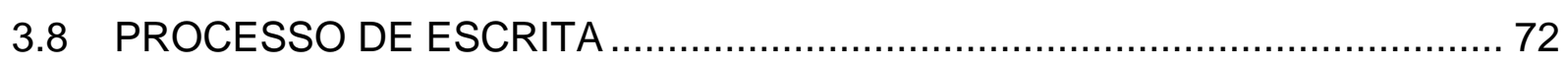

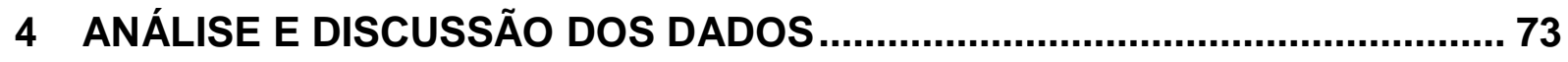

4.1 SOBRE A IMPORTÂNCIA DAS FERRAMENTAS DIGITAIS PARA O ELE .... 73

4.2 SOBRE FERRAMENTAS DIGITAIS PARA PRODUÇÃO AUDIOVISUAL....... 94

4.3 ATIVIDADES DE PRODUÇÃO AUDIOVISUAL E SUAS FERRAMENTAS ..... 96

4.3.1 Produção de Documentários e Audiolivros ................................................ 97

4.3.1.1 Ferramentas Relacionadas a esta Atividade ......................................... 100

4.3.2 Produção de Filmes e Vídeos em Geral ................................................ 101 
4.3.2.1 Ferramentas Relacionadas a estas Atividades .................................. 106

4.3.3 Produção Teatral ........................................................................... 107

4.3.3.1 Ferramentas Relacionadas a estas Atividades .................................. 110

4.3.4 Produção de Animações .................................................................111

4.3.4.1 Ferramentas para a Produção de Animações......................................114

4.3.5 Produção de Programas de TV e Rádio............................................... 114

4.3.5.1 Ferramentas para a produção e a transmissão radiotelevisiva ................116

4.3.6 Produção de Música e Dança ................................................................. 117

4.3.6.1 Ferramentas relacionadas a essas atividades .................................119

4.3.7 Oficinas de Escrita Criativa ................................................................. 120

4.3.7.1 Ferramentas de apoio à escrita criativa .......................................... 124

4.3.8 Ferramentas de Suporte à Autonomia ................................................. 128

4.3.9 Ferramentas para a coordenação dos projetos, interação e publicação ..... 132

5 CONSIDERAÇÕES FINAIS ...................................................................... 135

REFERÊNCIAS............................................................................................ 139

APÊNCICES ................................................................................................... 144 



\section{INTRODUÇÃO}

\section{"Knowing is not enough; we must apply. Willing is not enough; we must do." Johann Wolfgang von Goethe}

O ensino de línguas no Brasil possui algumas características peculiares ${ }^{1}$ que o faz ainda mais dependente de estratégias didáticas interacionais e ferramentas de telecomunicação para poder ser realizado em contexto mais dinâmico, autêntico e de livre experimentação. Dentre elas destacam-se três particularidades que desafiam professores e alunos a buscarem suplementos didático-pedagógicos para manterem maior contato com a língua-alvo: a) o relativo isolamento linguístico-geográfico deste país, visto que seu tamanho continental e sua unicidade idiomática tornam onerosa a tarefa de colocar-se em imersão nas principais línguas estudadas mundialmente; b) o ainda modesto acesso à internet de qualidade pela população, principalmente entre os mais carentes ${ }^{2}$, que os impedem de praticar a comunicação e o aprendizado em níveis mais elevados; c) o desconhecimento por grande parte dos professores de idiomas dos ganhos didáticos que os cursos podem obter através do uso de ferramentas digitais (FD) para estimular a produção comunicativa e assim impulsionar a aquisição linguística e a interação entre o corpo discente. Este último ponto foi observado principalmente nas duas escolas pesquisadas: Centro Interescolar de Línguas de Taguatinga (CILT) e Centro Interescolar de Línguas de Ceilândia (CILC).

Tais observações e a participação como docente em algumas escolas da rede de Centros Interescolares do Distrito Federal (CIL) - onde obtive suporte para experências

\footnotetext{
${ }^{1}$ Algumas destas características são mencionadas na página 75.

${ }^{2}$ Informações baseadas em: GOMES, Helton Simões. Pela $1^{\text {a }}$ vez, acesso à internet chega a 50\% das casas no Brasil, diz pesquisa. Portal G1, São Paulo, 15 set. 2015. Disponível em: <http://g1.globo.com/tecnologia/noticia/2015/09/pela-1-vez-acesso-internet-chega-50-das-casas-no-brasil-dizpesquisa.html>. Acesso em: 26 set. 2016.
} 
diversas relacionadas a produções audiovisuais com fins didáticos e pude observar experiências semelhantes de alguns outros professores - nos conduziram a duas perguntas que acreditamos serem essenciais para que os professores ainda alheios às possibilidades de uso de ferramentas digitais no ensino possam promover atividades que respondam melhor às características e necessidades dos modos de ensinar e aprender da atualidade:

1) Qual a importância das atividades de produção oral e escrita através dos meios modernos de comunicação e suas ferramentas para o ensino/aprendizagem de línguas?

2) Quais ferramentas têm sido mais facilmente absorvidas pelos professores de línguas nas escolas estudas para promover maior contato dos estudantes com a língua alvo e quais são consideradas como potencialmente relevantes para esse fim?

A primeira pergunta remete-nos a uma reflexão sobre a importância das ferramentas digitais para o ensino de língua estrangeira (ELE). Se considerarmos que uma das mudanças mais significativas observadas no mundo atualmente está relacionada às transformações nos modos de comunicação e interação interpessoais, provocada pelo advento dos tablets, smartfones e seus mais variados aplicativos, entre outras ferramentas digitais (FD) amplamente usadas pela população, responder a esta pergunta significa compreender melhor como o ELE deve comportar-se diante desse novo mundo. Como os cursos de idiomas necessitam responder também às novas necessidades comunicacionais dos alunos, é evidente que eles devem acompanhar tais mudanças e ressignificar-se, remodelar-se, para corresponder às expectativas e características da chamada Sociedade da Informação ${ }^{3}$. Portanto, conhecer melhor as razões que incitam os professores de línguas a buscarem constantemente absorver FD em seu ensino nos ajuda a compreender melhor a extensão das transformações citadas e

3 Termo também chamado de Sociedade do Conhecimento ou Nova Economia e atribuído ao economista austro-americano Fritz Machlup, referindo-se ao fato de a sociedade contemporânea estar inserida em um processo de mudança em que as novas tecnologias são as principais responsáveis. 
por que os professores precisam se atentar para esse novo contexto educacional que vem se moldando já há algum tempo.

A segunda, visa conhecer melhor quais ferramentas digitais os professores participantes desta pesquisa têm utilizado para promover atividades de produção audiovisual (APA) que possam, devido a sua completude em oportunizar o uso das quatro habilidades de comunicação ${ }^{4}$, envolver seus alunos em práticas genuínas de comunicação e interação. Responder isso nos ajuda a registrar e analisar atividades e projetos didáticos de considerável êxito e, assim, incentivar os professores ainda menos letrados no uso dessas novas ferramentas a se aventurarem em novos desafios comunicacionais capazes de empoderar os alunos à medida que parte da compreensão de que todos podemos produzir conteúdos audiovisuais, como contos, histórias em quadrinhos, animações, filmes, audiolivros, música, teatro, etc., e com isso alcançar maior competência comunicativa (CC) na língua estudada. Ainda, este trabalho visa encontrar no lócus de pesquisa e em outras fontes algumas ferramentas e atividades de potencial relevância didática que possam auxiliar professores e alunos com a produção destes conteúdos, tendo em vista que as limitações educacionais demandam por ferramentas simplificadas que possam permitir mesmo aos menos habilidosos com tecnologia a produzirem conteúdos de notável elaboração.

Cabe mencionar que o termo ferramentas digitais (FD) refere-se qualquer dispositivo eletrônico que permite edição ou gravação, textual ou audiovisual, de conteúdos informacionais (computadores, smartphones ${ }^{5}$, câmeras, gravadores, etc.) ou conteúdos disponíveis exclusivamente por meio virtual (sites, blogs, redes sociais, aplicativos, etc.).

\subsection{SOBRE O LÓCUS DE PESQUISA}

Fundados em 1975 a partir da criação do Centro Interescolar de Línguas de Brasília (CIL1), os CIL são popularmente conhecidos por sua excelência no ensino de idiomas e por serem opções acessíveis para os alunos da rede pública que desejam desenvolver-se em uma

${ }^{4}$ Referente às habilidades de compreensão oral, compreensão escrita, expressão oral e expressão escrita.

5 Palavra da língua inglesa que significa "telefone inteligente", ainda sem correspondente em português. 
ou mais línguas estrangeiras. Tal reconhecimento social que estes centros adquiriram ao longo do tempo tem sido o principal responsável pela sua ampliação. Atualmente o Distrito Federal conta com notáveis 11 (onze) unidades de Centros de Línguas, localizadas no Plano Piloto (duas unidades), Gama, Taguatinga, Brazlândia, Sobradinho, Ceilândia, Guará, Planaltina, Recanto das Emas e Santa Maria, conforme sugere SANT’ANA (2010, p. 2).

"Os CIL se destacam como escolas pioneiras no cenário da educação brasileira como centros públicos de ensino de línguas considerando que essa atividade alojada em escolas próprias tem sido característica da iniciativa privada e não do poder público" (SANT’ANA, 2010, p. 2)

Essa posição de destaque na rede pública do Distrito Federal foi construída devido ao engajamento de seus professores e gestores que se empenharam para distanciar-se dos modos de ensino praticados nos Centros de Ensino Médio do Distrito Federal (CEMDF), pois estes se caracterizam por fornecer um ensino de idiomas meramente instrucional e insuficiente quanto à promoção da fluência oral dos alunos. Vale ressaltar que um dos grandes responsáveis por isso é o fato de que estes CEMDF, assim como a maioria das escolas públicas do Brasil, não possuem estruturas adequadas ao ensino de idiomas, visto que suas turmas são muito grandes (40 alunos em média) e poucos possuem ambiente com material audiovisual suficiente. Nem mesmo a carga horária ${ }^{6}$ é considerada suficiente para que os alunos possam adquirir fluência em uma língua estrangeira (LE) no ensino médio e esse ponto é um dos mais criticados por professores e alunos.

Uma característica notável dos CIL é que, diferentemente dos CEMDF, os professores devem demonstrar fluência oral e escrita no idioma a ser lecionado em prova prática e teórica aplicada pelos coordenadores dos cursos. Caso contrário, estes professores ficam restritos a ministrarem aulas nos CEMDF até reavaliação futura. Isso fez com que os CIL se dotassem de profissionais qualificados a promover certa competência comunicativa em seus alunos. Isso produziu um efeito muito positivo, pois são as histórias de sucesso de

${ }^{6}$ Atualmente os alunos dos CEMDF contam com menos de duas horas semanais de aulas de língua inglesa e menos de uma hora por semana para o estudo da língua espanhola. 
inúmeros alunos que conseguiram desenvolver-se em idiomas estrangeiros a maior vitrine destes centros, representando os frutos de um plantio feito com visível competência.

A maioria destes CIL possui laboratórios de informática, aparelhos de gravação e reprodução audiovisual e diversos outros materiais didáticos de apoio ao ELE. Seus professores costumam trabalhar tanto as habilidades escritas como orais em suas estratégias didáticas e boa parte dos alunos formados por eles demonstram notáveis habilidades de comunicação em LE. Estes centros costumam também promover festas e eventos culturais com a finalidade de tratar de temas transversais, integrar-se com a comunidade, promover parcerias com entidades filantrópicas, arrecadar recursos para a ampliação de seus recursos didáticos, entre outras atividades que os ajudam dialogar com a sociedade e seus representantes políticos.

Entretanto, percebe-se certa inquietação por grande parte dos professores dos CIL, principalmente nos centros estudados nesta pesquisa (CILT e CILC), pois apesar de serem considerados centros de excelência e possuírem bons resultados, os professores percebem que, assim como indicamos neste trabalho, alguns problemas relacionados ao ensino de línguas no Brasil são endêmicos e independentes da qualidade de formação dos professores. Essa é a razão de alguns professores, como os informantes desta pesquisa, estarem se aventurando no uso de ferramentas digitais como tentativa de promover maior contato dos alunos com a língua alvo através de atividades de produção audiovidual (APA) ou da simples interação comunicativa. Dessa forma, acreditam estarem criando rotinas didáticas que deixem o ambiente escolar mais propício à aquisição de língua estrangeira (ALE), tornando a escola mais presente também no mundo virtual e na educação à distância.

Se a história destes centros foi marcada por avanços e retrocessos, conforme identifica Sant'Ana (2010), esta história continua e atualmente enfrenta outros desafios relacionados às mudanças nos modos comunicativo-interacionais citadas que o mundo vem vivenciando. Para mais informações sobre a história destes CIL faz-se oportuno indicar quatro trabalhos que mostram como mudanças político-pedagógicas interferiram ou ajudaram na construção destes centros de excelência que lutam para atualizar-se, assim como o conceito de excelência se atualiza com o passar do tempo.

O primeiro trabalho encontra-se no mesmo texto anteriormente citado (SANT'ANA, 2010) e registra um pouco de seus problemas e avanços. O segundo (DAMASCO, 2012), ao tratar da história do ensino de línguas no DF contempla também parte da história dos CIL. Já o terceiro e o quarto são mais completos quanto a informações históricas, procedimentais e situacionais destes centros: a dissertação de Mesquita (2013), que também registra parte dessa 
história, entre outras políticas educacionais de ELE, e a tese de Damasco (2014), que registra impressões de jovens, docentes e da comunidade sobre os CIL junto a também um pouco de sua trajetória.

Coadjuvantes nesta história, os centros onde se deu esta pesquisa (CILT e CILC) servem como laboratório para alguns professores que vêm percebendo a importância de absorver as modernas ferramentas digitais de comunicação no ensino e servindo de expoentes de novas estratégias e propostas didáticas com o intuito de renovar as práticas e rotinas escolares.

Essa renovação passa por sua modernização não meramente relacionada ao uso de dispositivo mais avançados, senão por uma profunda reflexão sobre qual o perfil contemporâneo do ensino de línguas e quais mudanças podem ser experimentadas para que ele acompanhe as transformações sociais e possa suprir as necessidades comunicacionais dos alunos, bem como responder aos anseios da comunidade escolar por um ensino mais célere, dinâmico e pluriestratégico. Entre as diversas estratégias possíveis, percebe-se que o uso destas ferramentas para fomentar entre os alunos uma produção comunicativa qualificada, a fim de impulsionar a aquisição e o uso linguístico livre, tem sido mais comum por apresentar expressivos resultados, observados por toda a comunidade escolar e evidenciados nesta pesquisa.

\subsection{SOBRE OBJETIVOS E MODO DE APRESENTAÇÃO TEXTUAL}

Uma vez que a escolha do objeto de estudo desta pesquisa foi influenciada não somente pela observação de projetos exitosos em promover a aquisição linguística através do estímulo à produção criativa apoiada em FD, mas também pela constatação de grande resistência por boa parte do corpo docente ao uso de novas tecnologias de comunicação e produção audiovisual - seja provocada pelo receio de que elas possam aumentar a carga de trabalho dos profissionais de educação ou pela pouca habilidade destes com as ferramentas de informática - esta pesquisa sempre objetivou servir aos professores ainda avessos, ou alheios, a estas novas propostas didáticas de consulta para professores que desejam ampliar o uso da língua-alvo entre seus alunos. 
Seu valor teórico foi buscado através da compactação de algumas das principais considerações disponíveis no mundo acadêmico sobre a aquisição linguística, competência comunicativa e da construção de diálogos entre acepções teóricas e as vantagens relacionadas à produção comunicativo-interacional para o desenvolvimento da fluência oral entre os alunos.

Seu valor prático foi construído pela compilação e proposição de algumas atividades de produção comunicativa e de algumas ferramentas que possam servir aos professores como referência ou inspiração para que então possam aventurar-se em novas estratégias com maior segurança e confiança nos resultados positivos possíveis, seja pelo conhecimento destas ferramentas potenciais e suas possibilidades didáticas, seja pelo registro de experiências de sucesso de alguns professores informantes junto a um diálogo epistemológico exercido pela contemplação e análise de suas vozes ao participarem desta pesquisa.

Para tanto e seguindo convenções que visaram uma construção fluída e sequencial, a apresentação deste trabalho é feita através de prévias considerações teóricas sobre os benefícios da produção audiovisual para o ELE, as características da competência comunicativa interpessoal - onde é feita uma apresentação de um modelo recente de CC (baseado em Almeida Filho, 2009), por perceber que a forma como vemos esta competência molda todas as estratégias e conteúdos do curso de idiomas - e as acepções teóricas em que esta pesquisa se baseia. Tal base está fundamentada primariamente sobre a Teoria da Compreensão (KRASHEN, 1982), a Hipótese do Output (SWAIN \& LAPKIN, 1995) e perpassa outras teorias que defendem as vantagens da interação para a aprendizagem.

Secundariamente e baseando-nos em PAIVA (2014), apresentamos sob o título de Teorias Complementares alguns traços de outras acepções teóricas que possam nos permitir um diálogo entre elas e os objetivos desta pesquisa. Isto posto sem perder de vista o interesse em desenvolver um olhar integrador em relação ao valor das acepções teóricas, isto é, vistas sob a ótica da Perspectiva da Complexidade, baseada nos trabalhos de Larsen-Freeman (1997) e Paiva (2002), que relacionam a Teoria do Caos/Complexidade às características dos sistemas linguísticos e sua aquisição.

Em seguida, é apresentada a base metodológica desta pesquisa, de caráter qualitativo, com o intuito de justificar sua natureza e relatar os procedimentos e estratégias em que ela está sustentada, além de expor algumas considerações sobre o tipo diverso em que se deu este trabalho (pesquisa-ação) e seus instrumentos de coleta de registros.

Enfim, os registros obtidos e transformados em dados de pesquisa, por sua categorização, são apresentados e analisados de modo a evidenciar o que tem sido feito nas 
escolas estudadas em relação ao uso de ferramentas digitais no ELE, quais as visões dos professores informantes e quais atividades e ferramentas possuem notório valor potencial para promover maior contato dos alunos com a língua estudada.

Com vistas a nutrir tanto o corpo docente quanto discente com informações que possam contribuir para a construção de seu embasamento teórico, tivemos o intuito de construir mais uma visão panorâmica sobre algumas atividades e ferramentas didáticas do que a eleição de uma proposta somente e seu aprofundamento teórico e experimental. Esperamos com isso servir como base consultiva e motivar futuros projetos e pesquisas que possam comprovar de forma mais específica os valores de cada proposta didático-comunicativa. Sabemos que nenhuma pesquisa se encerra em si mesma e que cada uma possui trajetória ímpar, ou seja, é o diálogo e a complementação entre elas que, em uma perspectiva construtivista, são capazes de promover as transformações necessárias para o desenvolvimento de professores e alunos, entes fundamentais das instituições educacionais de um país. 


\section{REFERENCIAL TEÓRICO}

\subsection{BENEFÍCIOS DA PRODUÇÃO AUDIOVISUAL PARA O ELE}

De acordo com H. Douglas Brown $(1994,53 ; 214)$ "o êxito do aprendizado em turma (ou grupo) depende muito de como os estudantes relacionam e cooperam entre si”, cabendo ao professor de línguas cinco papéis principais para fomentar a aprendizagem: a) controlador, tipo que determina o que os estudantes devem fazer e quando devem falar, dando pouca oportunidade à interação espontânea; b) diretor, tipo que busca promover uma interação real entre os alunos e, como o maestro de uma orquestra, faz alguns gestos ou toma algumas atitudes para direcionar a conversa de modo a ser mais produtiva; c) gerente, tipo que planeja atividades, trabalhos e o quando tratar de cada tema, mas ao mesmo tempo abre espaço para o surgimento da criatividade e iniciativa individuais, desde que estejam dentro de seus parâmetros; d) facilitador, que por sua vez é menos controlador e busca fazer do aprendizado uma tarefa menos árdua e o mais natural possível, simplificando todos os processos de aprendizagem; e) professor-fonte, que está sempre disponível para orientar, aconselhar e instruir os alunos à medida que eles o buscam, funcionando como uma enciclopédia.

Márcio da Silva \& Rottava (2015; p. 7) observam também que tanto professores quanto alunos têm seus papéis remodelados e aperfeiçoados com o passar do tempo, assumindo novas formas e funções:

\footnotetext{
"Os desafios, entretanto, fazem parte do que Felix (2005) denomina metas educacionais, as quais refletem uma mudança de papel tanto para professores quanto para aprendizes, uma vez que estas se expandiram e passaram a incluir "aprendizado ao longo da vida (lifelong learning), interação global, aquisição de conhecimento e habilidades meta-cognitivas e processos que incluem curriculum negociado e professores e informantes reais" (p. 85). Tais fatos refletem o contexto de ensino/aprendizagem de línguas comum nos dias atuais, o qual proporciona inúmeras possibilidades e impactam no próprio processo e nas instituições, visto torná-los "flexível, inclusivo, colaborativo, autêntico, relevante, global e efetivo" (Felix, 2005, p. 86). Devido a tais características, Felix argumenta que estas indicam uma modificação na abordagem de ensino, pois se torna necessário envolver os aprendizes em tarefas autênticas que refletem situações reais, dando ao sujeito poder em relação ao formato do curriculum para atender a demandas e necessidades diversas" (MÁRCIO DA SILVA \& ROTTAVA, 2015; p. 7).
}

Nota-se que cada papel é importante para que o professor exerça sua função de forma plena e mais efetiva. No que se refere aos objetivos desta pesquisa, ao se tentar utilizar novas ferramentas e tecnologias no ELE, o professor compulsoriamente desenvolve cada uma destas 
características, pois as complexidades de determinadas atividades, como produção de curtametragens, audiolivros e animações, por exemplo, demandam maiores responsabilidades por parte de seus alunos, que passam a ver-se como os principais agentes do aprendizado, e ao mesmo tempo exigem do professor habilidades para planejar o que vier a ser produzido, promover a interação entre os integrantes, orientar a execução das atividades e encorajar a criatividade interdisciplinar em seus alunos.

Ao estimular a interdisciplinaridade, o ensino de idioma apresenta também utilidades extralinguísticas, pois nos exemplos de produção citados devemos supor que a maioria dos alunos deverá também desenvolver habilidades que abordam desde o conhecimento das características de cada produção até a utilização das ferramentas (aplicativos virtuais, dispositivos eletrônicos, funcionalidades básicas da informática, etc.).

Celani (1992) considera que a interdisciplinaridade vem se tornando característica cada vez mais marcante da área da Linguística Aplicada (LA), atingindo, além dos conteúdos, as metodologias de pesquisas oferecidas por diferentes tradições, em disciplinas diversas, conforme Costa (2001; p. 3) salienta:

\footnotetext{
"Os estudos realizados por Gomes de Matos (1996) também caracterizam a LA como área interdisciplinar que tem o objetivo principal de contribuir para uma compreensão mais abrangente e aprofundada de problemas e dos mais variados resultados da (inter) ação comunicativa humana, como também de buscar soluções relevantes possíveis e preferíveis, para tais problemas e, por fim, ter uma consequente humanização comunicativa de pessoas, grupos e comunidades maiores" (COSTA, 2001; p. 3).
}

De fato, a LA nunca foi uma área fechada em si mesma, pois seu objeto de estudo (a língua e suas manifestações socioculturais) é um dos mais universais e multidisciplinares que existem. Com o ensino de línguas não é diferente, pois para estabelecer-se de forma holística ele precisa ver a língua como veículo de exposição e absorção de conhecimentos e as áreas de conhecimento como potenciais artigos de interesse didático e experimental. É então que as práticas de produção comunicativa e conhecimentos tecnológicos se complementam para proporcionar aos aprendizes experiências autênticas de comunicação interativa. 
Outras vantagens advindas das inserções de modernas tecnologias audiovisuais para promover atividades de produção artístico-pedagógicas ${ }^{7}$ direcionadas à aprendizagem de língua estrangeira repousam no que Brown (1994) chama de aprendizagem cooperativa e interativa, abrindo espaço para a consideração de alguns pressupostos da Teoria da Compreensão (KRASHEN, 1982). Entre eles, cabe ressaltar o natural monitoramento do uso ideal do idioma feito pelo praticante à medida que prepara uma atividade que posteriormente poderá ser gravada, filmada ou editada em aplicativos de produção visual. Isso ocorre devido à própria natureza cooperativa dessas atividades que promovem o aperfeiçoamento da pronúncia e o entendimento das regras de uso do idioma.

Entretanto, como esse tipo de aprendizado consciente das normas linguísticas "tem um papel limitado na performance em língua estrangeira” (KRASHEN, 1982), há de se observar também algumas outras características que promovem a aquisição linguística, como a constante prática da língua alvo, à medida que os participantes dão e recebem instruções e opiniões, ou quando constantemente encontram formas de se expressar dentro da LE e desenvolvem um estilo próprio de falar, que representa um passo muito importante para o adquirente da língua, pois promove uma naturalização da forma de falar e uma aproximação da língua alvo com a linguagem idiossincrática do estudante.

Krashen (1982) ainda defende que os estudantes devem adquirir competência linguística suficiente antes de serem incentivados a falar, senão os filtros afetivos (ansiedade, motivação e autoconfiança) estarão em nível alto, bloqueando em parte a aquisição linguística. Portanto, tarefas que sirvam como pretexto para que o aluno seja motivado a praticar a comunicação em meios diversos proporcionam uma aprendizagem mais significativa, pois à medida que o aluno se vê como protagonista para realizá-las desenvolve sua competência comunicativa e, consequentemente, adquire maior segurança em comunicarse.

Dessa forma, as atividades que utilizam aplicativos e dispositivos que têm forte ligação com o cotidiano dos alunos, além de forte afinidade com suas aspirações mais elementares, promovem uma motivação generalizada em sua realização, trabalhando também

\footnotetext{
7 Atividades de produção artística com fins pedagógicos, isto é, focadas nos processos de aprendizagem e superação e não na qualidade do produto final.
} 
sua autoestima, e reduzindo, assim, os citados filtros, bem como promovendo um aprendizado mais relevantes e duradouro. Vale ressaltar que a autoestima está ligada ao sentimento de poder e capacitação, fomentados duplamente pelo domínio das modernas ferramentas audiovisuais à sua disposição e pela própria aquisição linguística, pois essa é uma habilidade empoderadora.

Outra relevante consideração diz respeito ao que Krashen chama de comprehensible input (insumo compreensível), que representa toda e qualquer amostra linguístca que é exposta aos alunos de forma compreensível e sem traduções, proporcionando uma assimilação mais natural dos itens de expressão linguística. Esse termo parte da ideia de que os falantes que aprendem uma língua através da imersão - no ambiente real em que a língua alvo é usada e sem apoio obrigatório de livros ou traduções simultâneas - são favorecidos à medida que a faculdade de linguagem comum a todos os seres humanos trabalha de forma plena e natural. Desse modo, tudo o que é aprendido torna-se mais relevante e o falante reproduz os termos de acordo com suas funcionalidades e guiados por uma experiência prática obtida não pela conscientização formal, ou gramatical, dessa língua, mas sim pelo uso real, em que a efetiva comunicação é mais importante do que o modo e o nível em que ela se dá.

Isso posto, esses conceitos ganham sobressalência neste trabalho quando observamos que a característica principal das atividades audiovisuais mencionadas é a prática interativa e criativa do idioma, que, por sua vez, promove também o desenvolvimento do falante interculturalmente. Tais ideais estão diretamente ligados à necessidade de empoderamento dos educandos promovido pelas abordagens educacionais que visam desenvolver sujeitos mais críticos sobre o mundo que lhes é apresentado pelas instituições ou pela sua comunidade. Essas atividades têm como característica principal permitir que os alunos experimentem os conteúdos em nível além do informacional, podendo reconstruí-las e até mesmo criá-las para enriquecer o processo de ensino/aprendizagem. É então que a competência comunicativa pode ser desenvolvida em ambientes mais autênticos, com liberdade produtiva pode construir novos sentidos, enredos e símbolos.

Consequentemente, a importância do desenvolvimento de uma competência comunicativa além do mero conhecimento de características estruturais da língua é fundamental, uma vez que, para estabelecer-se uma efetiva comunicação, conhecer somente as regras gramaticais figura-se como insuficiente, demandando ao aprendiz conhecer também regras de uso (HYMES, 1972). É ao desenvolver estratégias diversas para conseguir manter o fluxo comunicacional e obter êxito na interação social que ele se mostra capaz, pois a 
aquisição ocorre de forma gradual e os eventos de comunicação frequentemente exigem do falante uma competência em nível acima da que ele está. Logo, ensinar comunicativamente envolve proporcionar aos aprendizes experiências diversas em que possam ser desafiados a usar o código linguístico para transmitir uma mensagem suficiente e adequada aos contextos universais e intersubjetivos.

Canale \& Swain (1980) e, posteriormente, Canale (1983) já demonstravam a importância de considerar também alguns aspectos estratégicos, discursivos e sociolinguísticos para o desenvolvimento de uma $\mathrm{CC}$, ou seja, aprender uma língua não é somente olhar para o seu código linguístico, mas também desenvolver um modo de interagir socialmente.

Sagarra \& Zapata (2008) realçam alguns desses pressupostos juntamente com a importância de os alunos estarem efetivamente engajados na construção do conhecimento, ao invés de atuarem como replicadores e absorvedores passivos de informação, e experimentarem maior controle sobre a aprendizagem (minha tradução, assim como as demais desta dissertação):

\begin{abstract}
"O empoderamento dos estudantes está relacionado com o sentimento dos estudantes de que o computador lhes permite tornar-se ativamente engajados na construção e no uso de seu conhecimento, ao invés de agirem como duplicadores e absorvedores passivos de informação (Collentine, 2000; Sanaoui \& Lapkin, 1992; Warschauer \& Meskill, 2000). O controle do aprendiz sobre a aprendizagem fomenta o pensamento crítico, a motivação e a realização por que o maior controle os permite escolher a sequencia de seu aprendizado (Hannafin \& Colamaio, 1987; Steinberg, 1989), negociar sentidos via computador (Kern, 1996) e acomodar seu estilo de aprendizagem (Bull, 1997)".
\end{abstract}

Exemplo de como é válido envolver o aluno em atividades comunicativas reais vistas por este trabalho como práticas não mecanizadas de uso da língua, como drills, repetições, etc., que possam promover um uso significativo da língua - e que estejam alinhadas aos aspectos contemporâneos da comunicação.

Ora, se a comunicação no mundo moderno se dá também por meios não tradicionais, representados por novos modos possibilitados pelo advento das modernas tecnologias de telecomunicação, nada mais natural do que absorver essas novas formas de interação no ensino, dado que se ensina um idioma para o seu uso integral nos diversos atos comunicativos. Isso demonstra a importância de haver entre os docentes constante atualização de suas práticas e planejamentos estratégicos para criar um ambiente em que a aquisição seja propiciada também pela interação com o mundo e suas tecnologias, além dos aspectos de interação interpessoal imediata. 
A criação desse ambiente de interação apoiado em FD é o que chamamos de blended learning (ensino híbrido). Ribeiro (2014, p. 72) define tal ensino no excerto abaixo:

\begin{abstract}
"O ensino híbrido, portanto, é a combinação do aprendizado online com o offline, em modelos que mesclam (por isso o termo blended, do inglês "misturar") momentos em que o aluno estuda sozinho, de maneira virtual, com outros em que a aprendizagem ocorre de forma presencial, valorizando a interação entre pares e entre aluno e professor. A parte online disponibiliza o auxílio de recursos digitais, os quais permitem que o aluno tenha controle sobre sua própria aprendizagem, ou seja, onde, como, o que e com quem vai estudar. Nesse sentido, os dispositivos móveis, como tablets e smartphones, e a facilidade de utilizá-los em diferentes ambientes abriu o leque de possibilidades sobre onde esse componente pode ser desenvolvido: dentro da própria sala de aula, na biblioteca, no laboratório de informática e até em casa" (RIBEIRO, 2014, p. 72).
\end{abstract}

Tal modo de ensinar tem se mostrado como um caminho natural devido a dois motivos principais: o surgimento de FD de interesse do ensino em geral e o aproveitamento de suas potencialidades por professores e alunos. É fato que as tecnologias têm um poder incontestável na sociedade, pois costumam simplificar processos e rotinas, e que à medida que se popularizam costumam transformar a vida dos indivíduos a tal ponto que chegam a cogitar a impossibilidade de viverem sem elas. Da mesma forma vem acontecendo com o ensino de línguas. Sua relação de dependência como as FD, principalmente às destinadas ao aperfeiçoamento da comunicação ${ }^{8}$, vem crescendo exponencialmente e já é possível prever que em um futuro próximo o professor que não dominar algumas delas estará impossibilitado exercer suas funções de forma suficiente. Portanto, podemos ver com certa urgência a necessidade do surgimento de proposições didáticas que contemplam o uso de FD como estratégia de ensino.

Com base nessas considerações, tais propostas são apresentadas neste trabalho como potencialmente facilitadoras para muitos professores que se esforçam de forma demasiada,

${ }^{8}$ Vale citar que nesta pesquisa não desenvolvemos os conceitos de TIC (Tecnologias de Informação e Comunicação) ou TI (Tecnologias de Informação) por acreditarmos que sem ter que submetermos a estes conceitos poderíamos desenvolver uma pesquisa mais livre e que pudesse identificar também algumas ferramentas digitais criadas para outros propósitos, porém úteis para algumas das propostas de produção audiovisual apresentadas nesta pesquisa. 
porém sem obter os resultados esperados. Também, podem assumir um caráter consolador, pois é comum depositar grandes expectativas e exigências sobre os professores, que normalmente correspondem melhorando suas práticas, mas nem sempre são observados esforços suficientes para a transformação do curso em si, seus recursos, estruturas e sistemas educacionais. E é esse, no nosso modo de ver, um dos pontos-chave para a melhoria dos cursos: a modernização das instituições educacionais, que pode ser acompanhada pela simples observação da produção cultural de seus integrantes e do modo distinto de interação epistemológica que estão construindo.

\subsection{A COMPETÊNCIA COMUNICATIVA}

Desde que Hymes propôs em seu artigo On Communicative Competence (1972) um modelo de CC não idealizada, em resposta à ideia de falante ideal chomskiano, levando em consideração as diversas adequações a que o falante se submete tanto para inserir-se em um meio quanto para superar suas deficiências linguísticas, muitos outros autores têm buscado propor modelos que possam responder ao que o aprendiz de língua precisa saber e quais são as habilidades mais relevantes para o êxito na comunicação interpessoal.

Tais construtos são objeto de estudo e exposição nos mais variados livros, artigos, dissertações e teses relacionados à área de linguística aplicada, dentre os quais podemos destacar três devido a suas características sintéticas e simplificadas: "Conhecendo as Regras do Jogo: a Competência Comunicativa e os Manuais Didáticos de Ensino de Inglês como língua estrangeira" (ALMEIDA, 2011), que avalia também a consistência comunicativa dos manuais didáticos; Principles of Language Learning and Teaching (BROWN, 2007; 246270); e El Concepto de Competencia Comunicativa (CENOZ IRAGUI, 2004).

Entretanto, o termo Competência Comunicativa é mais amplo e, dependendo do tipo de comunicação estudada, pode referir-se tanto a habilidades interpessoais como telecomunicacionais, em que técnicas específicas podem fazer parte das habilidades desejadas. Por exemplo, no meio corporativo, devido à necessidade de maior dinâmica e efetividade nas apresentações de projetos, reuniões, etc., é comum o termo "design de apresentações" que se refere ao modo como um tema é proposto a um grupo de forma a captar sua atenção, interesse e afinidade. Nesses casos o construto de competência comunicativa considera características da fala, como fala não linear, objetiva, funcional, etc., e aspectos paralinguísticos, como olhar, expressão facial, expressão corporal, etc., como muito relevantes para o êxito comunicacional. Da mesma forma, no meio acadêmico é possível que 
estudiosos incluam em seu construto de CC habilidades que não sejam imprescindíveis para que o falante consiga estabelecer a interação, expressar-se de forma adequada e manter o fluxo comunicacional.

Portanto, há a necessidade de apresentação de um modelo de CC mais sintético, isto é, suficiente às mais elementares habilidades necessárias para o estabelecimento da comunicação. Respondendo a essa necessidade, o modelo proposto pelo professor Almeida Filho (UnB/2015) e desenvolvido por alguns de seus alunos (citados na ilustração a seguir) apresenta as habilidades fundamentais de que o falante se vale para fazer operações linguísticas adequadas aos mais diversos contextos interacionais. Esse modelo está em constante análise, porém acreditamos representar os três pilares mais importantes da interação verbal dialógica, assim como o tripé representa a configuração mínima de estabilidade para as estruturas. Ele responde a quais habilidades devem ser fomentadas no ensino, bem como qual a configuração ideal do ensino de línguas para que possa ser mais comunicativo e refletivo das necessidades mais urgentes dos alunos, conforme ilustrado e descrito a seguir:

Figura 1 - Modelo de Competência Comunicativa

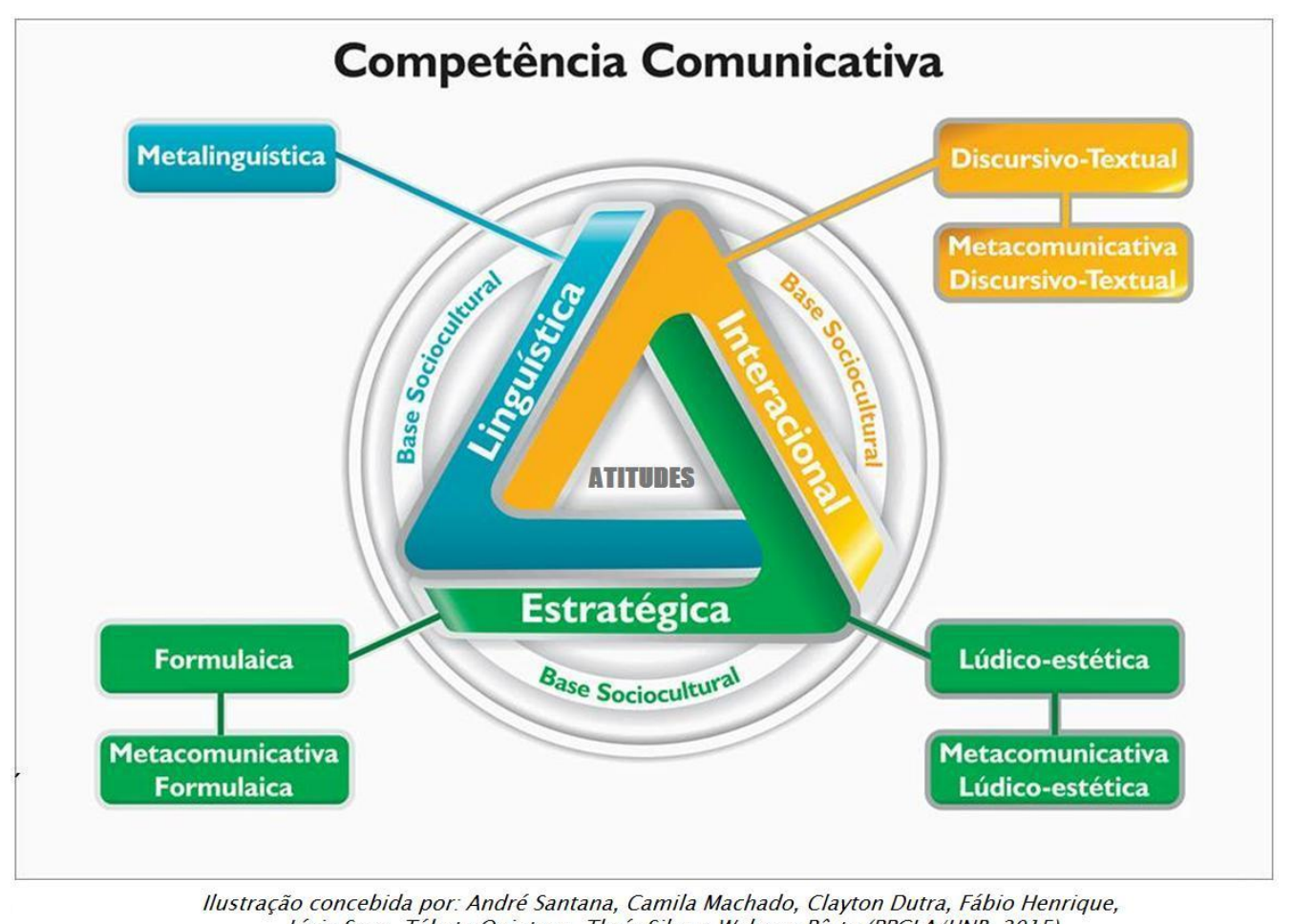

Lígia Sene, Tábata Quintana, Thaís Silva e Walesca Pôrto (PPGLA/UNB, 2015)

(Trabalho ainda não publicado, baseado em Almeida Filho, 2009) 
Esta ilustração busca representar que as três principais competências são observadas de forma complementar nas atitudes comunicativas dos indivíduos e que cada competência apresenta hierarquicamente sua subcompetência que, por sua vez, indica que o não conhecimento explícito de suas propriedades não impede que o falante demonstre fluência comunicativa. Ainda, ao ser cada componente apresentado sobre a Base Sociocultural que todo falante possui e que se figura como um dos fatores mais importantes de diferenciação entre os falantes, sugere que as habilidades linguísticas, estratégicas e interacionais são desenvolvidas de modo a ignificar o código linguístico para viabilizar a expressão do ser e suas mais idiossincráticas aspirações socioculturais. Ela molda as "Atitudes" (Fig. 1) dos falantes e também é sensível às mudanças de atitudes, ou seja, uma alteração em uma interfere na outra. A seguir uma descrição mais detalhada de cada competência:

- Linguística: domínio do código linguístico em uso;

- Metalinguística: conhecimento explícito da estrutura do código linguístico e sua taxonomia;

- Interacional: domínio das possibilidades de interação e negociação dos significados, bem como a criação de contextos intersubjetivos;

- Discursivo-textual: capacidade de coordenar as estruturas e significados para construir um texto articulado e promover um efeito desejado de comunicação;

- Estratégica: domínio das possibilidades compensatórias e recursivas da língua, como paráfrase, substituições, simplificações, etc.

- Formulaica: capacidade de usar os padrões de expressão linguística para manter o fluxo comunicacional ou adequar-se às regras socioculturais;

- Lúdico-estética: capacidade de recriar ou remodular as combinações linguísticas para fins artísticos, cômicos, lúdicos, etc.

- Metacomunicativas Formulaica, Lúdico-estética e Discursivo-textual: conhecimento explícito das dinâmicas e complexidades dessas subcompetências.

Apesar da importância de cada componente ser relativa diante às necessidades comunicacionais dos estudantes e de essas subcompetências não agirem de forma dissociada umas das outras, pois cada produção comunicativa depende de suas combinações múltiplas, e algumas parecerem mais evidentes em alguns períodos textuais, a seguir apresentamos breves considerações sobre cada uma, com vistas a clarificar mais o modo como são percebidas. Vale mencionar que toda atitude comunicativa é feita sobre uma base sociocultural desenvolvida 
pelo falante ao longo de suas experiências interacionais e por fatores ainda academicamente desconhecidos. Mais considerações sobre ela serão feitas a seguir em momento oportuno.

\subsubsection{Subcompetências Linguística e Metalinguística}

A dinâmica da fala permite liberdade discursiva e recursiva, o que torna difícil distinguir se o uso equivocado de alguma forma estrutural se dá por uma atitude momentânea, por um conhecimento de regra ainda não sedimentado no uso oral ou mesmo pelo desconhecimento dela. Isso demonstra a distância existente entre forma e uso, língua ideal e língua real ou língua escrita e língua falada, pois a habilidade sugere o uso de uma competência, sendo estes dois termos praticamente indissociáveis.

Contudo, no caso do uso linguístico essa relação ganha uma complexidade um pouco maior, uma vez que há muitos aspectos estruturais, gramaticais, que estão em desuso ou que o uso social difere frequentemente, reservando-os para os momentos em que tal formalidade é exigida e incitando o falante à prática da diglossia. E é esse termo umas das chaves da comunicação. Apesar de seu conceito não ter sido originalmente proposto para definir situações de uso em que o falante é impelido a modificar sua linguagem para atender às especificidades do contexto, hoje é comumente usado com este sentido (FERGUSON, 1959).

"Em sua tese de pós-doutorado, ainda não publicada, Sayeedur Rahman (2006:134) define a Diglossia como referente a uma situação onde diferentes variantes linguísticas coexistem para executarem diferentes funções sociais dentro de uma comunicadade de fala" (FERGUSON 1959; p. 336).

O conhecimento dessas habilidades mutantes nos falantes também ajudou a expor um dos motivos do insucesso das abordagens estruturalistas de ensino de línguas quando usadas para atender às expectativas atuais de domínio linguístico prioritariamente oral, pois as estruturas se dinamizam, se transformam na fala para seguir um determinado propósito, evidenciando a importância de habilidades e competências que possam dar conta da verdadeira missão do código linguístico: a comunicação. E ela costuma ser feita de modos plurais mesmo dentro de uma mesma comunidade, atendendo desde as necessidades mais informais às mais formais dos contextos sócio-interacionais existentes.

Portanto, o conhecimento linguístico é independente do conhecimento metalinguístico, sendo este uma compreensão analítica e taxonômica que, apesar de ser desejável devido aos ganhos expressivos que pode oferecer aos aprendizes, não sugere que 
seu domínio refletirá na fluência oral ou que seu desconhecimento impedirá o falante de apresentar notável competência comunicativa. O que muitos falantes demonstram é um conhecimento tácito das estruturas e possibilidades comunicativas, conformando sua competência linguística, que os permite obterem relativo êxito comunicativo, podendo recorrer a exercícios gramaticais, interpretativos ou produtivos para aperfeiçoar seus modos de expressão.

\subsubsection{Subcompetências Interacional e Discursivo-Textual}

Podemos dizer que o conhecimento linguístico está subjulgado às regras interacionais, visto que a comunicação, sua principal razão pragmática, efetiva-se por algum modo recíproco, como uma via de mão dupla em que cada participante tem seu turno, seu tempo de atenção e resposta. A partir das diversas possibilidades recursivas da língua, que precisam ser tão complexas e variadas quanto os contextos situacionais possíveis, cada falante recria as combinações linguísticas de forma a corresponder às expectativas comunicacionais e expressar algo relativamente novo, baseando-se nas suas experiências, conhecimentos, informações, ideologias, aspirações, motivações, emoções, tradições, etc., ou seja, a base sociocultural, que, por sua vez, é o fator de diferenciação da produção textual dos discursos, também diversos.

É essa base que colore o discurso nas diversas funções textuais, como a persuasão, o ensino, a informação, a correspondência, o pleito, etc. Por exemplo, ao fazer uma pergunta específica a diferentes usuários da língua se obterá respostas diferentes, não somente por terem domínios linguísticos díspares, mas principalmente porque a língua é um reflexo do que somos. Se somos seres com histórias, momentos e graduações distintos, nada mais natural do que agir de modo idiossincrático e imprimir em nossa maneira de falar nossas peculiaridades individuais.

Então, percebemos que saber colocar-se em interação, fazendo as adequações e negociações de sentido, é fator preponderante na comunicação e, como os modos interacionais também apresentam disparidades entre as culturas, observamos que estudar sobre a cultura da comunidade de contato é importante para enriquecer a base sociocultural do aprendiz para ampliar sua abrangência e sua qualidade comunicativa. Como exemplo, podemos citar eventos acadêmicos, como colóquios, mesas redondas, ciclo de palestras, etc., em que é visível como os que dominam o assunto vigente, ou seja, os que o tem agregado à 
sua base sociocultural, se sentem mais a vontade para colocar-se em interação e participar de forma mais ativa das atividades em geral.

\subsubsection{Subcompetências Estratégica, Formulaica e Lúdico-estética}

Conforme já citado, a habilidade de encontrar formas diversas de expressar-se, compensando eventuais inconsistências ou falhas da competência linguística é muitas vezes crucial para a comunicação, uma vez que a aquisição também é um processo gradual. Essa é uma das estratégias comunicativas que permitem que o interlocutor mantenha-se interessado de formas tanto passiva como ativa, cooperativa, auxiliando os dialogantes na expressão de suas ideias. Dentre as diversas estratégias de comunicação, podemos citar algumas essenciais: fala simplificada; empréstimo das estruturas e ideias do interlocutor; uso do tempo presente em narrativas; repetição de ideias; paráfrases para explicar-se melhor; fala empática para manter uma relação amigável como entrevistador; etc.

Essa concepção de modelo de CC é muito importante para o ensino, pois é seguindo seus rastros que ele deve ser pensado. Por exemplo, ao perceber a importância de o falante colocar-se em interação, ainda que não possua competência linguística completa para isso, as ações educacionais tendem a valorizar o desenvolvimento de estratégias comunicacionais nos alunos. Ainda, ao perceber que a competência linguística e metalinguística não possuem relação de dependência, o ensino molda-se à medida que busca desenvolver um uso pragmático anterior ao conhecimento formal das estruturas e taxonomias linguísticas. Da mesma forma, a valorização excessiva de uma só habilidade, ou subcompetência, condena o curso a uma insuficiência didática e seus alunos a experimentarem uma abordagem instrumental do código linguístico que pode levá-los ao desinteresse, pois começam a perceber que os esforços de aprendizagem não refletem em sua fluência oral e que o curso não é capaz de habilitá-los para a interação nos diversos modos e contextos comunicativos.

Assim sendo, percebemos que as habilidades estratégicas são imprescindíveis ou para a manutenção do fluxo comunicacional ou para agregar uma qualidade específica à interação, podendo determinar o modo em que se dará tal interação, se com ares de formalidade ou informalidade, comicidade ou austeridade. E não devemos esquecer que, apesar de ser possível identificar qual subcompetência está sendo usada preponderantemente em um determinado trecho do discurso analisado, a produção verbal se dá pela ignificação sincrônica de todos esses componentes que conformam a competência comunicativa, pois 
funcionam como engrenagens onde cada componente é basilar para a manutenção de seus movimentos. As habilidades linguísticas unem-se às habilidades estratégicas e interacionais para moldar-se o discurso e imprimir uma competência comunicativa, que é socialmente construída.

\subsection{AQUISIÇÃO DE LÍNGUA ESTRANGEIRA}

A partir de uma perspectiva integradora - inspirada pelos trabalhos de LarsenFreeman (1997) e Paiva (2002) que relacionam a Teoria do Caos/Complexidade às características dos sistemas linguísticos e sua aquisição - capaz de considerar as teorizações sobre aquisição linguística como complementares, ou seja, não apenas concorrentes. E considerando que, em uma visão pragmática da aprendizagem instruída, as teorias de aquisição linguística servem pra nos dizer o que deve conter em um curso de idiomas para que a aprendizagem ocorra de forma mais efetiva e menos morosa, busco nesta seção extrair dentre as principais considerações teóricas sobre a aquisição linguística o que cada uma pode contribuir para a prática de ELE.

Ao discernirmos que cada teoria busca compreender melhor os fenômenos linguísticos e dar indicações de como funcionam em complexidade, podemos encontrar na prática de ELE parâmetros e até mesmo diretrizes para aperfeiçoar as práticas docentes: a mais-valia social de cada construto teórico. Isso se alinha com a primeira fase da Linguística Aplicada, em que o ensino e aprendizagem de línguas eram o foco principal. Posteriormente esse ramo de estudo se ampliou focalizando questões de uso de linguagem em diferentes contextos e com diferentes propósitos comunicativos (PEREIRA \& ROCA, 2009), mas a história dessa área de estudo tem mostrado que o diálogo entre a teoria e a prática é necessário e inevitável, pois toda teoria sofre pressões a respeito de suas possíveis utilidades para a área acadêmica e a sociedade em geral.

Vale mencionar que, apesar de os termos "Aquisição de Segunda Língua” (ASL) e "Aquisição de Língua Estrangeira" (ALE) não serem sinônimos, esse trabalho considera que os esforços teóricos para discernir o funcionamento de uma são extensíveis à outra, semelhante à visão de Paiva (2014). Dessa forma, apresento considerações sobre a Perspectiva da Complexidade (PAIVA, 2002) com o intuito de fundamentar os motivos que me levam a dar crédito aos construtos presentes nesse trabalho e as assimilações mais significativas encontradas em cada teoria que possam nortear-nos quanto aos elementos 
indispensáveis a uma prática de ensino/aprendizagem de línguas otimizada, atual e consistente.

\subsubsection{A PERSPECTIVA DA COMPLEXIDADE}

Apesar de muitos acadêmicos acharem que a aplicação dessa teoria na área da linguística é superestimada (HORGAN, 1995), a Teoria do Caos (visto este aqui como imprevisibilidade e não desordem, conforme DE BOT, 2008) e da Complexidade demonstra que um sistema complexo e dinâmico, como é o sistema linguístico e sua aquisição, não pode ser compreendido a partir de uma visão estática e polarizada, pois possui diversas características que inviabilizam seu tratamento apenas de forma sincrônica ou diacrônica. Dessa forma, faz-se necessário compreender cada uma das características desse sistema para poder relacioná-las com a importância de ver a ALE em uma perspectiva agregadora que demonstre que cada teórico considera um ponto, ou um instante, desse sistema dinâmico, como um retrato de um movimento aleatório que evidencia apenas uma de suas múltiplas nuances. Como um filme que é formado por diversos quadros estáticos que só fazem sentido ao serem unidos ou coordenados.

Sua dinamicidade sugere que os sistemas complexos nunca se assentam. Estão em um processo de formação constante em que pode haver avanços e retrocessos - sem considerar essas duas palavras com uma visão maniqueísta, pois um retrocesso nesse caso pode ser apenas um retorno a uma forma anterior, que, por sua vez, pode ser algo desejável, benéfico, ou não. Sugere ainda que são observáveis de forma pouco exata ou concreta, já que a norma, ou moda, momentânea está sujeita à passagem do tempo e às interações entre os componentes do sistema, apresentando uma geometria fractal onde cada unidade tem sua importância na configuração do todo. Isso lhe dá uma estrutura orgânica formada pela interação entre seus membros ou unidades. No caso da ALE observa-se também uma intangibilidade que dificulta muito sua abordagem de forma única, absoluta e suficiente. Provavelmente, essa é a razão de existir tantas teorias e abstrações e, ainda assim, permanecer como fenômeno desconhecido em sua totalidade.

Sua imprevisibilidade, modo randômico e abertura às interferências externas evidenciam a dificuldade de criar regras sem exceções ou encaixar um de seus componentes em todos os contextos ou momentos angulares, vistos nesta pesquisa como instantes de uso ou variante atual da língua, em analogia à dinâmica pendular descrita a seguir. É essa 
característica que fortalece as considerações sobre a abordagem comunicativa, pois regras gramaticais podem não se equiparar às regras de uso (HYMES, 1972), e explica as possibilidades de variação linguística, pois, segundo os demais sistemas complexos, apresenta uma dependência sensível às condições iniciais (PAIVA, 2014), porém absorvendo novidade, energia, do meio ambiente em que se está em uso.

Seu aspecto não linear demonstra que a aprendizagem, ou aquisição linguística, não segue um passo a passo rígido. Ainda que possam ser identificados alguns pré-requisitos para a apreensão de formas mais complexas ou dividir um curso em básico, intermediário e avançado, não se pode impedir que algumas formas básicas não sejam aprendidas no nível avançado, ou vice-versa. Essa característica demonstra por que métodos muito sistemáticos como o audiolingual, por exemplo, apresentam dificuldades em formar comunicativamente os aprendizes, uma vez que a comunicação se dá em meio também dinâmico, randômico e imprevisível.

Outra característica importante dos sistemas complexos é sua capacidade de adaptação e auto-organização. Tanto os sistemas em si quanto a compreensão que se têm sobre eles, as teorias, são sensíveis ao feedback (resposta ou retorno significativo). Isso nos conduz naturalmente a uma visão construtivista, dado que o choque e a interação epistemológica são desejáveis à medida que promovem o aperfeiçoamento das considerações qualitativas (não empíricas), aproximando-as da verdade, como um texto de autoria pluralizada que está sendo escrito, revisto e reescrito constantemente. Dessa forma os sistemas se adaptam a novas evidências e se auto-organizam eliminando as possíveis debilidades teóricas ou pragmáticas.

Podemos então considerar as teorias sobre ALE como representações de sistemas complexos e que o sistema em sua complexidade representa a verdade (vista aqui como ponto ideal), porém suas características conhecidas e evidenciadas pelas pesquisas representam uma aproximação a essa verdade. Usando a metáfora do pêndulo, é possível ilustrar a importância de cada teoria e perceber que ainda é preciso descrever muitas trajetórias novas para compreender todas as possibilidades existentes no sistema, conforme ilustrado a seguir: 
Figura 2 - Metáfora do Pêndulo

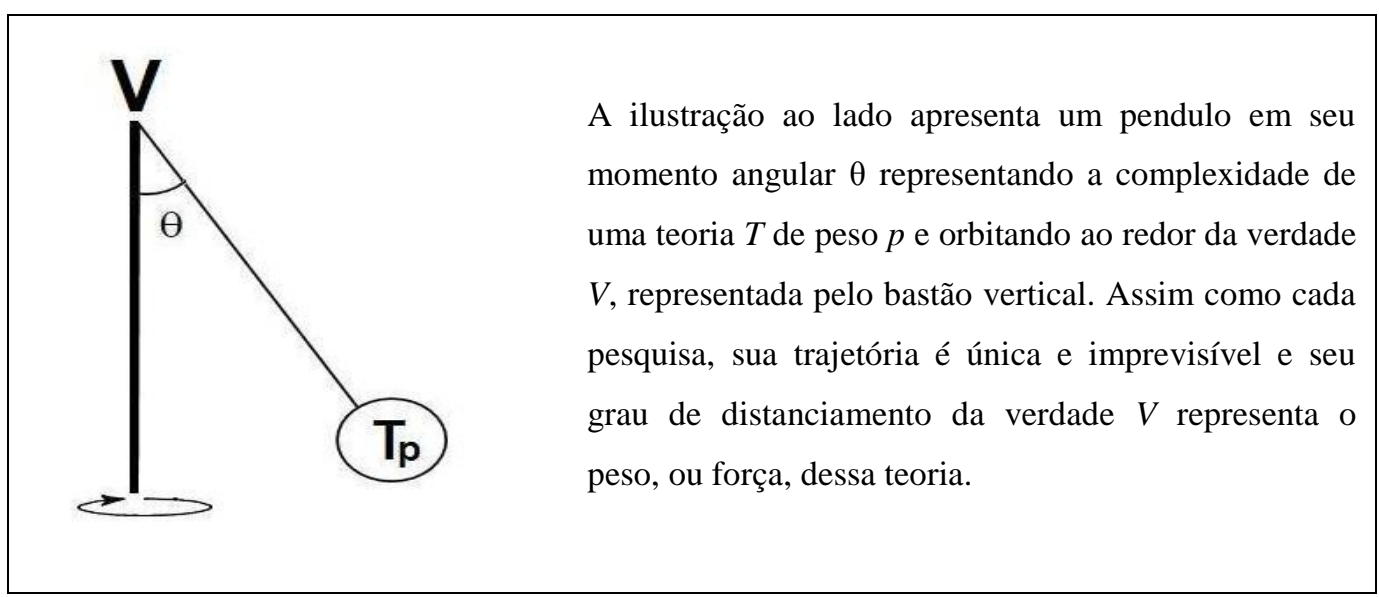

(original desta pesquisa)

Apesar de o pêndulo ser sensível às energias externas e apresentar trajetórias sempre distintas, tende a aproximar-se do bastão $V$ devido ao que chamamos de atrator estranho: força não previsível que limita sua órbita, responsável pela tendência de aproximação ao ponto $V$. É o ponto para o qual os sistemas evoluem e é chamado de estranho por ser desconhecido ou imprevisível. No sistema linguístico ele representa a característica observável de mudança que as línguas estão sujeitas, porém sempre mantendo certos parâmetros, ou seja, as transformações promovidas pelo uso e o ambiente interativo estão relativamente limitadas pelas regras mais indispensáveis para a obtenção de sentido em uma determinada língua.

Paiva (2014, p. 149) apresenta uma esclarecedora ilustração de como cada perspectiva teórica pode ter trajetórias distintas e se interseccionarem em alguns momentos, semelhante à figura 3, pois cada uma explica um elemento do mesmo fenômeno. Cada órbita representa uma visão diferente e seu percurso ao redor de um ponto de onde se possa ter uma visão holística, uma compreensão total do fenômeno representada pelo ponto central.

Figura 3 - Representação Orbital das Teorias

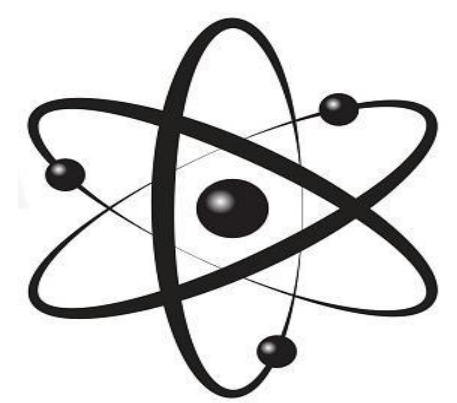

(https://d2gg9evh47fn9z.cloudfront.net/thumb_COLOURBOX10152474.jpg) 
Dessa forma e visando absorver o legado de cada teoria para o ensino de línguas, principalmente, apresentamos a seguir algumas das principais teorias sobre aquisição linguística - usando a terminologia mais usualmente conhecida, dado que alguns autores têm preferido outras nomenclaturas - junto a valores práticos que observamos em cada. É possível que haja um estranhamento por parte de alguns leitores sobre a importância da contemplação de uma teoria ou outra, uma vez que apenas três (Hipótese da Compreensão, Teoria do Output e Teoria da Interação) se encontram no foco principal de interesse dessa pesquisa, porém isso se justifica pelo intuito desta pesquisa de servir como referência de consulta e amadurecimento teórico para professores e alunos e pelo fato de serem observáveis também em outras teorias, que neste trabalho chamamos de complementares, a importância das práticas de produção linguística para o desenvolvimento do falante.

\subsubsection{GRAMÁTICA UNIVERSAL}

Apesar de focarem no conhecimento linguístico dos falantes nativos e em como produzem e compreendem as expressões, isto é, sua competência linguística na língua materna, a escola gerativista postulou questões e hipóteses indispensáveis para o desenvolvimento da linguística moderna. Ao contrapor-se às escolas estruturalistas, que se atinham somente à classificação dos elementos do corpus linguístico (SEARLE, 1972), e behavioristas (comportamentalistas), que propunham um tratamento da aprendizagem humana como análoga às observações experimentais com seres não dotados de linguagem, Chomsky deu um novo fôlego à linguística, inspirando diversos estudos posteriores e servindo também de alvo para críticas, principalmente por idealizar um falante perfeito como objeto principal de estudo e por não considerar algumas funções da linguagem e aspectos sociais, pragmáticos ou fatores individuais (PAIVA, 2014).

Em sala de aula, as considerações chomskianas ${ }^{9}$ são relevantes à medida que uma compreensão melhor por parte do corpo docente sobre a natureza da linguagem possa refletir no tratamento do aprendiz como portador de capacidade inata, como já sugeria Platão, e

${ }^{9}$ Referente ao linguista, filósofo, cientista cognitivo, comentarista e ativista político norte-americano, reverenciado em âmbito acadêmico como "o pai da linguística moderna". 
idiossincrática: a linguagem interna, que permite o pensar antes mesmo da verbalização. Esta capacidade tem caráter potencial e precisa da experiência para desenvolver-se, encontrando no meio de comunicação um repertório linguístico e uma destreza na combinação de palavras para que possa expressar-se de maneira suficiente, desenvolvendo assim sua linguagem externa, linguagem observável e sujeita aos padrões e restrições sociais. Tal linguagem externa é também o que chamamos de desempenho e ele é variável, pois pode ser afetado por perdas momentâneas de memória, pela dinâmica e ritmo da fala, por fatores socioculturais, etc. Daí a importância de criar-se situações de uso significativo da língua para promover o desenvolvimento das habilidades de expressão.

Para a ALE é válido observar que, exceto em alguns casos de deficiência física ou mental, os seres humanos possuem uma série de ferramentas pré-dispostas ao desenvolvimento de um idioma: a LAD (Language Acquisition Device), ou DAL (Dispositivo de Aquisição Linguística). Ela habilita o aprendiz a diferenciar sons, imitá-los, memorizá-los, organizá-los de forma significativa e colocá-los em ação para promover a comunicação. Entretanto, esse dispositivo não funciona de forma linear e controlada e é a negligência desse fato que desabilita um pouco as formas tradicionalistas de aprender um idioma, representadas por métodos estruturalistas e comportamentalistas, a serem usadas exitosamente para o desenvolvimento da oralidade, pois é visível a dificuldade que temos em aprender um idioma apenas a partir de suas fórmulas gramaticais.

Precisamos perceber a gramaticalidade das expressões através da adequação das possíveis combinações de unidades linguísticas usando-as na comunicação real e significativa, uma vez que, como vimos nas características de sistemas complexos, a língua é usada em situações pouco controláveis, imprevisíveis, dinâmicas, sensíveis a estímulos externos, autoorganizáveis, etc. Essa característica nos remete a mais uma consideração chomskiana útil: a diferença entre aquisição e aprendizagem.

Apesar de ambos os termos poderem ser usados como sinônimos, sua distinção é importante à medida que demonstra que a LAD pode agir em sua forma mais natural (semelhante à observada na aprendizagem da língua materna) e através de artifícios didáticos. Adquirir uma língua é assimilá-la na interação significativa com seus falantes e aprendê-la é conscientizar-se de sua estrutura e possibilidades, exigindo maior esforço intelectual. No ambiente nativo a aprendizagem ajuda a desenvolver a expressividade do falante, seja por meio da instrução ou por atividades autônomas. No contexto não nativo ela serve para sintetizar, organizar e antecipar os elementos da língua de forma a dotar o aprendiz com 
estruturas possíveis de uso e viabilizar uma aceleração da aquisição linguística, senão o aprendiz teria que ter uma quantidade muito grande de experiências para se deparar com determinadas possibilidades linguísticas e começar a percebê-las em uso.

Apesar de haver tradicionais construções teóricas que consideram que a aquisição de um idioma só pode acontecer em ambiente nativo e haver considerações sobre o período crítico para adquiri-lo, atualmente elas são praticamente obsoletas diante dos estudos modernos e conhecer esses aspectos nos faz repensar todo o ensino de idiomas de forma a permitir que em qualquer idade ou configuração sociogeográfica possa haver aquisição. Faznos reconsiderar qual o espaço que a prática significativa da língua tem em sala de aula e qual o momento mais adequado para tratar dos itens gramaticais, das listas de verbos irregulares, das atividades escritas, da leitura e demais atividades que levam o aluno em direção à aprendizagem consciente. Põe-nos dúvidas sobre a efetividade de atividades de repetição, como drills, por exemplo. Enfim, nos leva uma reflexão sobre as características que a disciplina LE não compartilha com as disciplinas que envolvem majoritariamente aspectos cognitivos.

Consequentemente, ao buscar aperfeiçoar as práticas docentes, o professor pode encontrar atalhos para um ensino mais agradável e motivador para todos, pois não há nada mais frustrante na aprendizagem de uma língua do que sentir-se incapaz, ou inseguro, de usála oralmente para expressar sua CC (normalmente já presente na L1), mesmo conhecendo várias de suas estruturas e fórmulas. Isso gera uma reação em cadeia, na qual os professores se sentem impotentes diante das diversas dificuldades inerentes à aprendizagem de LE em comunidades onde ela é escassamente usada e o aluno sente dificuldade em perceber seu aprendizado e o valor do curso, pois a fluência oral costuma ser seu objetivo principal.

A Teoria Gerativa também evidencia algumas características complexas dos sistemas linguísticos ao perceber que a "pobreza de estímulos" recebida pelo falante não corresponde à sua competência e ao identificar suas características recursivas, onde os elementos se inter-relacionam, gerando processos formalmente finitos que, por sua vez, geram possibilidades quase que infinitas. Saber disso nos possibilita tratar a língua de forma mais adequada, pois ela não nos diz onde ela começa ou onde termina, analogamente aos sistemas complexos.

No Ensino, tais características sempiternas nos mostram que não há passo a passo para absorver o sistema linguístico e, apesar de haver a necessidade de categorizar seus elementos, a comunicação real se configura em um campo semântico holístico, principalmente, ou seja, saber suas partes isoladas ou desconectadas ajuda pouco na 
comunicação. Então, não há necessidade de esperar que o aluno aprenda o presente para ensinar o passado, ou tentar criar um ensino controlado, em que os avanços imediatos são precisamente observáveis, como era práxis no método Audiolingual, ou ainda considerar ser possível uma aprendizagem em marcha, como fazia o ASTP (Army Specialized Training Program), desconsiderando aspectos individuais e a importância do contexto comunicativo.

\subsubsection{HIPÓTESE DA COMPREENSÃO}

Baseadas nas considerações chomskianas e em estudos contemporâneos à sua jornada acadêmica, as hipóteses de Krashen (2002) obtiveram força por refletirem intuições compartilhadas entre os participantes do desafio de aprender uma língua estrangeira. Suas contribuições para a Linguística Aplicada são proeminentes, por sintetizar alguns princípios básicos relacionados à assimilação de um idioma.

Ao sugerir que todos adquirimos a língua da mesma forma, porém desenvolvendo-a segundo fatores individuais, ele mantém seu foco na configuração imprescindível que o contato com a língua alvo deve ter para ser capaz de produzir um falante fluente, análoga ao ambiente de aquisição da L1. O ponto de partida em suas considerações é a comunicação real, com expressões significativamente relevantes para a interação linguística que, por sua vez, promove a aquisição, em contra mão ao tratamento linguístico relativamente estéril dos métodos estruturalistas.

Ao corroborar a distinção entre aquisição e aprendizagem, Krashen evidencia que a LAD é guiada pelos sentidos inerentes à palavra e seu contexto e que há na mente humana uma espécie de amadurecimento linguístico provocado pela quantidade e qualidade de Insumo Compreensível (Comprehensible Input) recebido pelo aprendiz. Devido às características holísticas citadas, durante esse período de conformação do sistema linguístico é natural um certo "período silencioso", em que é preciso desenvolver melhor o repertório linguístico para poder aventurar-se no uso. Esse é um momento de experimentação e participação dialógica mais moderadas e sugere que as habilidades de compreensão são anteriores às de expressão, assim como alguns elementos linguísticos são adquiridos anteriormente a outros (Natural Order Hypothesis).

É fato que, ao aprender qualquer língua, desenvolvemos mais as habilidades de compreensão do que as de expressão e que o falante possui uma fala distinta e idiossincrática, porém, devido a seu percurso de aprendizagem e influências socioculturais, os aprendizes 
tentem a desenvolver um modus loquendi diferente de seu usado na L1. Isso dificulta sua construção de identidade na LE e sua expressão ideológica, por não encontrar facilidade em externar sua fala interior dentro de um sistema comunicacional ainda pouco experimentado, por características naturalmente destoantes entre ambas as línguas ou por não conhecer a equivalência exata de seu modo de falar habitual.

Tais características comuns aos iniciantes reforçam a importância de prover os níveis básicos com muita informação e experimentação, mas sem perder de vista que o que realmente vai contar para a fluência é a aquisição linguística, deixando sua conscientização principalmente para atividades extraclasse. A partir de então, vemos a necessidade de fazer o aluno perceber primeiramente as regras usando-as, e só então conhecer suas fórmulas e pronúncias exatas.

Entretanto, a carga horária dos cursos em geral é insuficiente para que se dê a atenção necessária para a interação significativa, daí a importância de novas estratégias para que os alunos tenham mais contato com a língua e, consequentemente, absorvam mais insumo. Nesse processo novas tecnologias e atividades artístico-comunicativas podem auxiliar à medida que promovam também o desenvolvimento da autoestima discente, sua motivação e uma prática em baixo nível de ansiedade.

Estes três pontos são chaves da teoria de Krashen: motivação, ansiedade e autoestima. Configurando o Filtro Afetivo, estes fatores são considerados os principais responsáveis para que a aquisição ocorra de forma ideal. Se, por um lado, um alto nível de ansiedade - provocado principalmente pela dificuldade de transpor à LE a mesma fluência da L1 em atividades que demandam um nível além do atingido - pode bloquear essa absorção de insumo; por outro, autoestima e motivação são ferramentas indispensáveis para a instalação e continuidade desse processo. Enquanto a primeira empodera o aprendiz com a sensação de que conseguirá desenvolver a competência almejada, a segunda serve de combustível para prosseguir superando as barreiras e dificuldades do idioma.

Dessa forma, é esperado que o professor busque construir um ambiente em que a configuração de todas essas variantes seja favorável ao processo. Para tanto, são válidas iniciativas que busquem aproximar a língua da realidade e cultura do aluno, pois ele precisa motivar-se e encontrar razões socioculturais que o motivem. Há a necessidade também de identificar-se com histórias de sucesso. Dominar o simples e então o mais complexo, a comunicação básica e utilitária antes de análises sintáticas e taxonomias gramaticais.

Ainda, o aluno precisa encontrar no ambiente escolar outras habilidades e temas transversais que o possam guiar para um enriquecimento extralinguístico, ou seja, usar a 
língua para aprender coisas e apresentá-las, ensiná-las; participar de atividades lúdicas e artísticas onde possa enfrentar eventuais acanhamentos, retraimentos, inseguranças, etc., conferindo maior valor ao curso de línguas, caracterizado por ser um curso multidisciplinar onde é possível apreender informações sobre as mais diversas áreas do conhecimento. Nesse ambiente cabem cursos de poesia, de música, de interpretação, de locução radiofônica, de TV e cinema, etc. Qualquer habilidade satélite à comunicação é bem vinda à medida que ajude a desenvolver no aluno sua $\mathrm{CC}$, o resultado mais imediato da aquisição.

Krashen considerava também ser mais fácil o aprendiz absorver imperfeitamente os itens comunicativos de um idioma e em seguida tornar sua fala mais precisa, clara e desenvolvida, à medida que pela aprendizagem consciente ele percebe o que pode melhorar, do que buscar desde o início da aquisição usá-los com perfeição em todas as operações linguísticas. Enquanto a aquisição é responsável por produzir um falante fluente - não o falante ideal chomskiano, mas alguém comunicativamente competente - a aprendizagem permite que, em um monitoramento da fala (Monitor Hypothesis), o falante possa editá-la, atentando-se à forma, ou seja, adequando sua produção a uma determinada regra, desde que ele a conheça e tenha tempo suficiente, uma vez que o uso do monitor tende a reduzir o ritmo da fala e a impressão de fluência no idioma.

É essa compreensão que orienta os professores a permitirem o iniciar de uma fluência nos adquirentes com traços não sincrônicos à gramática normativa e, a partir de então, prover os alunos com informações e práticas que possam ajudá-los a aperfeiçoar a pronúncia, a apropriação das expressões, o léxico, etc. Uma exigência sobre a forma nos níveis iniciais pode apenas gerar uma configuração desfavorável do filtro afetivo, aumentando a ansiedade e bloqueando esse processo natural. É melhor a criação de um ambiente de livre experimentação e focado no campo semântico, mas sem perder de vista a importância do feedback e das aulas instrucionais, pois eles podem ajudar o aluno a perceber nuances em sua produção capazes de torná-lo mais exitoso na comunicação.

\subsubsection{HIPÓTESE DO OUTPUT}

A teoria de Krashen não prevê um elemento muito importante para aquisição: a experimentação significativa (vista aqui como qualquer produção não meramente repetitiva), uma vez que nem toda expressão compreendida pelo aprendiz fará parte de seu rol de produção, ou repertório. Há um tipo de insumo que só é adquirido através da experimentação 
linguística em atividades de produção em geral, oral e escrita, e é responsável pela segurança que o falante tem ao expressar alguma ideia.

Esse insumo qualificado é fornecido por uma participação mais ativa do adquirente que, ao colocar-se em comunicação, testa hipóteses e expressões, podendo também perceber o vão que existe entre o que ele já consegue expressar e o que precisa aprender a expressar e, ao buscar preencher esse vão, melhora suas habilidades comunicativas.

Segundo Swain \& Lapkin (1995), em sua Hipótese do Output, ou Languaging Hypothesis (Hipótese da Produção), a produção linguística tem um valor complementar ao insumo, pois "aprende-se a falar falando" (apud PAIVA, 2014; 115). A partir da iniciativa de comunicar-se, o falante encontra-se com insuficiências em sua competência e é obrigado a buscar alternativas para expressar-se da forma mais precisa, coerente e adequada possível. Essa visão apoia a prática de colocar o aluno pra produzir mais do que ele sente que pode, mas a chave para seu sucesso está na forma como o aluno é impelido a falar, pois um dos fatores que mais aumentam a ansiedade dos alunos é a necessidade de falar (YOUNG, 1990). Caso o professor busque estratégias para capacitar o aluno antes de expô-lo à prática oral, como ler sobre um assunto antes de explicitá-lo, por exemplo, estimular a produção pode gerar excelentes resultados, ao passo que também cria oportunidades para a percepção da forma mais adequada, as possibilidades de paráfrase da língua, a tutoria direcionada à superação das limitações comunicativas, etc.

Apesar de haver registros experimentais de que só o insumo compreensível é suficiente para existir aquisição, também há registros de que os ganhos obtidos sem a experimentação produtiva são relativamente modestos, confirmando as possibilidades facilitadoras do output (ELLIS, 1995). De fato, é possível aprender o código linguístico até isoladamente de sua comunidade falante, porém é somente a partir do feedback dos falantes, fator importante defendido pela Hipótese da Interação (aludida a seguir), que o falante adquire suficiente confiança em sua CC. Isso reforça a importância de uma atitude menos passiva diante da aprendizagem e responde à comum dificuldade que os aprendizes têm em efetivar na comunicação algumas estruturas e expressões aprendidas ou adquiridas pela absorção de insumo somente.

Se considerarmos que muitas de nossas intuições docentes advêm das experiências que tivemos como aprendizes, acredito ser oportuno relatar minha experiência de aprendizagem das línguas inglesa e espanhola na Universidade de Brasília: 


\begin{abstract}
"Logo após ingressar no curso de Letras-Espanhol, sem saber mais do que ler textos de nível básico nesta língua, iniciei também o estudo da língua inglesa a partir de estratégias autônomas e da matrícula em disciplinas do curso de Letras-Inglês. Nessa jornada não foram raras as vezes que tive que apresentar trabalhos orais e escritos na língua alvo e, como não fazia curso de idiomas em nenhum outro lugar, utilizei uma estratégia peculiar para obter êxito nessas atividades já pré-agendadas e com pouco tempo para me preparar para elas: a preparação linguística para um evento específico de produção, consistindo em três passos. O primeiro era a pesquisa do tema para encontrar qual o texto matricial da minha apresentação; o segundo, um resumo desse texto, que demorava bastante tempo, pois, além de tentar aproximar as expressões da minha forma de falar, eram constantes as consultas sobre pronúncias e significados no dicionário; o terceiro era transformar o resumo em frases curtas que seriam memorizadas e escritas em uma folha para consulta, em caso de possível esquecimento na hora da apresentação. Além de obter considerável êxito nas apresentações, consegui desenvolver bastante minhas habilidades de expressão linguística à medida que observava o modo distinto de expressão da LE e o da minha língua materna, o português. Isso reforça meu apreço às observações de Swain \& Lapkin, porém, como isso não diminuiu consideravelmente a minha dificuldade em entender os falantes nativos da língua alvo, considero que sua teoria apenas complementa os postulados de Krashen" (prof. Fábio Henrique Barrozo).
\end{abstract}

Em suma, tanto o output como o input fornecem ao aprendiz modelos e fórmulas úteis para a estruturação natural do idioma em sua mente, isto é, direcionada aos significados e baseada em uma gramática intuitiva; não consciente de sua forma ou taxonomia. Ambas as fontes permitem que o aprendiz perceba os modos de expressão diversos e faça empréstimos linguísticos. Tudo o que falamos e todas as possibilidades de sentido das palavras têm origem em discursos ou possibilidades discursivas análogas anteriormente existentes.

Como exemplo, podemos citar os postulados da Teoria da Relatividade, proposta por Albert Eistein em 1905 (EINSTEIN, 1991), uma das mais admiradas descobertas da modernidade, pois para um observador reducionista ela pode ser vista como apenas uma combinação de palavras e significados, dentre outros signos já existentes. O que é realmente insigne é o discernimento científico que o levou a descobrir a ligação dessa combinação com a realidade do mundo físico. Consoantemente, podemos ver a língua como um conjunto de possibilidades que os aspectos socioculturais moldam ao longo de sua história de uso. E quando o aprendiz recebe insumos e os absorve, transformando-os em elementos prontos para o uso (intake), ele está na verdade escolhendo, entre muitas opções, uma forma específica de expressar-se. Todas essas formas unidas configuram sua CC que, por sua vez, é formada principalmente por habilidades linguísticas, interacionais e estratégicas.

No contexto escolar, observar essas características de uso linguístico nos auxilia criar um ambiente favorável ao desenvolvimento da CC: permissivo à negociação de sentidos comum à interação comunicacional; provedor de informações formulaicas do idioma; perceptivo das contribuições que atividades lúdico-artísticas podem fornecer à ASL; 
motivador do uso de estratégias para efetivar a comunicação, ainda que o aluno não sinta segurança para expressar uma ideia da forma mais adequada; criador de desafios orais e escritos para que os estudantes possam buscar superar suas limitações e desenvolver as competências linguística e discursivo-textual; entre outras funções satélites a estas. Em contextos onde o conhecimento metalinguístico é estimado, como no ensino direcionado a vestibulares, concursos, etc., observa-se que conhecer a gramática e suas nomenclaturas de forma consciente também pode trazer benefícios, principalmente em atividades em que é permitido um tempo maior de raciocínio antes de se expressar, como em redações, por exemplo.

\subsubsection{HIPÓTESE DA INTERAÇÃO}

Baseada nas teorias sociointeracionistas vygotskianas ${ }^{10}$, a Hipótese da Interação têm sido contemplada por diversas pesquisas que veem a interação significativa como algo fundamental para o desenvolvimento humano (ALMEIDA FILHO \& BARBIRATO, 2016). Essa interação, como já vinha sendo defendida nas considerações anteriores, é um fator muito importante para que tanto o input quanto o output se deem em ambiente naturalmente comunicativo e, consequentemente, significativo para a absorção das fórmulas linguísticas, propriedades discursivas e estratégias comunicacionais. Conforme defendido no capítulo sobre Competência Comunicativa, as habilidades interacionais são imprescindíveis para que o aprendiz se coloque em comunicação com o interlocutor, pois é a partir delas que ele observa e toma emprestadas expressões e formas, ou seja, ao aprender a interagir verbalmente o falante abre a porta para o desenvolvimento linguístico (HATCH \& LONG, 1978). Sem a interação não há negociação de sentido, verificação de compreensão ou uso de estratégias para manter o fluxo comunicativo (repetições, pedido de esclarecimentos, etc.). Portanto, ela nos leva em direção à importância de os aprendizes serem participantes mais ativos quando

10 Relativo psicólogo bielo-russo Lev Semenovich Vygotsky, descoberto nos meios acadêmicos ocidentais depois da sua morte, aos 38 anos. Pensador importante foi pioneiro na noção de que o desenvolvimento intelectual das crianças ocorre em função das interações sociais e condições de vida. 
recebem input (LONG, 1980), integrando as considerações de Krashen e Swain \& Lapkin anteriormente mencionadas.

Apesar de a interação também poder ser fonte de insumo inadequado, quando ela é guiada no ambiente de aprendizagem gera resultados consideráveis, visto que através de uma aprendizagem colaborativa é possível criar um ambiente que simula aspectos presentes somente ao imergir-se na língua alvo. Na verdade, considerando seu significado mais amplo, toda a aprendizagem se dá em meio interacional. Logo, podemos ver a interação como algo mais dinâmico, pois é possível interagir não somente com os participantes da aprendizagem, mas também com os temas apresentados, os textos, o ambiente, vídeos, áudios, aplicativos, etc., reconstruindo as informações externas em seu mundo interior, ou seja, absorvendo conhecimento.

Isso reforça a importância das dinâmicas comunicativas tão comumente experimentadas e permutadas entre professores de línguas, seja em workshops ou pela interação docente, como um modo de pesquisa natural, pois nelas já estão presentes o feedback dos aprendizes e os resultados observados. Dentre esses resultados são comuns relatos sobre o aumento da motivação, a contribuição das atividades lúdicas ou artísticas para a aprendizagem, desenvolvimento da autoestima, diminuição da ansiedade ao experimentar estruturas novas, entre outros. Tais atividades auxiliam a percepção (noticing) e uso desatento à rigidez da forma, ou seja, menos monitorado, possibilitando que os alunos experimentem, errem e, através do insumo envolvido no ambiente, corrijam-se, desenvolvendo na prática real suas habilidades de conversação.

Um grande passo a ser considerado sobre a interação na aprendizagem de LE é a observação das possibilidades de ganhos mútuos ao criar-se na instituição de ensino situações oportunas para a interação entre alunos de níveis iniciais e avançados, pois para que essa interação seja mais proveitosa é desejável que haja participantes com nível razoável de proficiência. De fato, a teoria da interação nos conduz às vantagens de colocar o aprendiz em imersão linguística, ainda que simulada, para que possa absorver insumo, porém essa interação pode dar-se de diversas formas, como já foi dito. Long descreve alguns benefícios de tal interação:

"falantes e escritores oferecem modelos do que é gramatical e aceitável ao aprendiz e, dependendo das circunstâncias, eles fazem adaptações para tornar a comunicação compreensível. Eles também dão feedback ao aprendiz sobre seus erros e fornecem explicações gramaticais. São essas modificações que tornam a mensagem mais compreensível e facilitam a aquisição" (LONG, 1996, p. 413). 
Esses benefícios, facilmente observáveis, representam a força teórica e prática que as teorias interacionistas mantêm no ambiente acadêmico e nos documentos educacionais, conforme podemos inferir a partir de Almeida Filho \& Barbirato (2016). Contudo, tal teoria deve ser vista de forma complementar às demais teorias expostas nesse trabalho, pois a interação por si só não é garantia de uma aquisição linguística consistente, posto que a interação também pode ser responsável tanto pela replicação de desvios linguísticos como pelo decréscimo da objetividade nos projetos de produção informativo-comunicacional propostos. O que faz realmente que ela seja benéfica ao desenvolvimento das habilidades em geral é o caráter cooperativo de todos os indivíduos, isto é, ela acontece de forma mais perfeita se todos os participantes estiverem focados em um objetivo e com práticas condizentes com as aspirações que compartilham.

\subsubsection{TEORIAS COMPLEMENTARES}

Uma vez contempladas as teorias que consideramos mais relevantes aos objetivos desta pesquisa, voltamo-nos a buscar de forma sintética entre as inúmeras teorias sobre ASL mais evidências na prática escolar de possíveis contribuições que os construtos aqui considerados como mais eminentes podem fornecer ao aperfeiçoamento do ensino. Porém, não foi possível descrever seus princípios epistemológicos neste trabalho, principalmente devido à suas limitações de tema e extensão textual. Dado que a aquisição é um fenômeno complexo e multifacetado, cada teoria sublinha apenas alguns de seus aspectos e ao reuni-los em uma abordagem pragmática é possível indicar mais práticas virtuosas e algumas propriedades que devem conter no ensino de línguas para que ele possa responder à demanda por celeridade na aquisição linguística e ser enquadrado como um curso moderno: transdisciplinar, tecnológico, autêntico, interacional, multitemático, atualizado, etc.

No ensino/aprendizagem em geral há fatores tanto cognitivos como psicossociais e as abordagens teóricas tendem a pender-se ou para o lado que considera os aspectos que assemelham a aprendizagem de LE a áreas do conhecimento onde processos objetivos de absorção instrucional são observados ou para o que considera os processos intrínsecos e exclusivos do tipo diverso de construção de conhecimento que a ALE representa.

Ambos os lados possuem sua importância, porém é ainda mais importante entender que nenhuma teoria representa uma espécie de pedra filosofal capaz de resolver todos os problemas ou superar todos os desafios que podem ser enfrentados tanto no ensinar como no 
aprender, pois mesmo que estes dois processos possam ser compreendidos de forma holística não se sobrepõem ao valor da laboriosa prática de promover a fluência linguística em comunidades de cultura e sociologia diversas.

Dentre as teorias que sublinham os aspectos cognitivos da aprendizagem podemos citar o Modelo ACT-R (Adaptive Control of Thought - Rational), a Teoria de Processamento da Informação, a Teoria Neurofuncional e o Modelo Conexionista. Tais construtos não costumam colocar em foco os tópicos subjetivos que podem interferir no processo de aquisição ou os fatores sociointeracionais que plasmam um modo distinto, grupal ou idiossincrático, de construção do conhecimento linguístico. O que eles buscam de fato é salientar fatores mais universais que possam estar relacionados com a absorção do código linguístico independente de seu contexto de aquisição e costumam ser concebidos a partir de percepções empiricistas de investigação acadêmica.

É fato que existem diversos aspectos cognitivos a serem considerados no ensino de línguas por serem capazes de promover um uso consciente do código linguístico principalmente em situações de uso onde o monitoramento das operações linguísticas é desejável por não interferir na fluência. Dentre essas situações destacam-se atividades de produção escrita (paráfrases, traduções, redações, etc.) e de produção oral não espontânea, vistas aqui como qualquer produção oral em que há uma oportunidade de preparação prévia para sua execução. Em atividades assim é possível conhecer melhor as diferenças entre ambas as línguas e fazer ajustes nos casos em que não há uma equivalência entre os modos de expressão, como mostram os exemplos a seguir (originais dessa pesquisa) que comparam algumas formas distintas de expressão entre o inglês e o português:

a) I wonder if you see what I'm getting at.

(Será que dá para entender onde quero chegar?)

b) I Wonder how much it costs.

(Quanto será que custa?)

c) I wonder who.

(Quem será?)

d) We can't help but see the tremendous problems affecting the modern metropolis.

(Não podemos deixar de perceber os problemas agudos que afetam as metrópoles modernas)

Para esses exemplos uma tradução literal seria imperfeita, posto que é visível a diferença entre os modos de expressão e suas sintaxes. Isso gera uma tendência no aprendiz a usar funções cognitivas para transpor o modo de pensar da língua materna para o modo da 
língua alvo, como no desenvolver de uma sub-competência formulaica, na qual o sintagma é absorvido de forma a substituir seu equivalente na L1 (exemplo: you're welcome = por nada), visto que seria muito oneroso mudar sua forma de pensar para adequar-se melhor ao inglês.

Tais percepções provêm do estudo comparativo e consciente dos idiomas e demonstram os ganhos que as práticas de análise linguística e tradução podem fornecer ao aprendiz, pois seria comum um brasileiro adquirente do inglês produzir frases como "It lacks only a few days to Christmas" ao invés de "There are only a few days to go before Christmas". Contudo, não podemos desconsiderar a possibilidade de tais adequações estarem presentes na aquisição, inconsciente, do idioma ou as possibilidades de variação linguística em usos regionais, bem como a criação de um tipo naturalizado de fala da língua estrangeira, como é o caso do Brazilian English que mantêm algumas características sintáticas, semânticas e fonéticas do português brasileiro na produção da língua inglesa, por exemplo.

Entretanto, os construtos meramente cognitivistas não são capazes ainda de interferir de forma ampla na didática e nas estratégias de ensino, pois fatores como a atenção, a motivação e o nível de absorção de conhecimento de cada indivíduo ainda são desconhecidos. Por isso é preferível priorizar a importância da criação de um ambiente favorável à aquisição, onde cada aluno possa superar suas limitações e apresentar resultados díspares, conforme suas características idiossincráticas de abordagem das informações, habilidades e conhecimentos. É esse ambiente de aprendizagem relacionado aos aspectos subjetivos o objeto principal de estudo dos construtos que observam os aspectos afetivos relacionados à aquisição linguística: Modelo da Aculturação, Teoria da Interlíngua, Modelo Cognitivo Interacionista, Teoria da Acomodação, Teoria Funcional Tipológica, Abordagem Orientada para o Conceito e Perspectiva da Identidade.

Por sua vez, as observações advindas dessas teorias focadas no sujeito e seu contexto nos levam a perceber algumas características individuais e sociointeracionais que podem surtir um efeito incisivo no modo de aquisição e sua qualidade. Fatores como motivação, ansiedade, autoestima, necessidades individuais, identidade, marginalização social, etc. também devem ser levados em consideração, pois tanto a importância da LE como seu modo de aquisição podem apresentar disparidades entre as regiões e suas comunidades. Daí a importância de encontrar em cada instituição de ensino um equilíbrio didático que possa ser ao mesmo tempo empoderador e inclusivo para os alunos, aumentando suas possibilidades de sucesso em seus diversos objetivos e tornando-os parte de uma comunidade mais cosmopolita, onde o conhecimento e o respeito às demais culturas são compartilhados. 
Apesar de uma determinada prática ser defendida por mais de uma teoria, as relações entre teoria e prática destacadas neste trabalho consideraram cada construto teórico de forma isolada devido à necessidade de investigação das características da ALE ressaltadas por cada um deles. Cabe mencionar que as teorias escolhidas estão elencadas como as mais relevantes por diversos autores, como Paiva (2014). Cada uma é vista aqui como representante das inquietações históricas a que se submeteram os linguistas, sua linha epistemológica e focos de interesses, ora pelos aspectos cognitivos da linguagem, ora pelos seus aspectos afetivos.

Cabe ao professor de línguas o conhecimento dos valores práticos para que, a partir da Perspectiva da Complexidade mencionada, possa absorver o que cada construto pode oferecer para sua busca de uma prática de ensino mais consciente e reflexiva. Dessa forma, tal práxis poderá ser mais consistente, principalmente se suas propostas didáticas dialogarem com as teorias fundamentais que historicamente ganharam relevância no meio acadêmico.

\subsubsection{SOBRE A MAIS-VALIA DAS TEORIAS APRESENTADAS}

A partir dessas considerações, entendemos que observar a potencial mais-valia social de cada construto teórico pode contribuir com a prática escolar, pois nos ajuda a exercer uma atividade didática mais consciente e embasada em assunções mais defensáveis, dado que muitas das teorias tratadas sofreram diversas críticas e se reconstruíram buscando um aperfeiçoamento epistemológico consciente de que não somente uma teoria dará conta da dinâmica da aquisição linguística e suas estruturas cognitivas e biológicas inatas, tamanha a grandeza de seus constituintes e contextos.

O que cada pesquisa conclui em suma é que há mais fatores relacionados à LAD a serem considerados do que se imaginava e que para adquirir uma língua é preciso de algo mais - ora visto como uma maior compreensão do processo, ora visto como uma demanda por maiores possibilidades interacionais e comunicativas para dinamizar e aperfeiçoar um processo que existe naturalmente, mas que não consegue desenvolver-se completamente sem fatores instrucionais e socioculturais.

Tal entendimento culmina na importância de propor a construção de um ambiente de aquisição linguística atualizado às possibilidades comunicativas contemporâneas, suas tecnologias e modularidades, pois a língua, como todo sistema complexo, está em constante movimento. E a sala de aula não é diferente. A cada momento surgem novos desafios e modos de comunicação diferentes e cabe ao professor uma constante marcha em direção a 
proporcionar ao corpo discente um ambiente constituído de múltiplas estratégias, recursos, atividades, possibilidades, etc., absorvendo o melhor de tudo o que está disponível e que possa ser útil ao desenvolvimento de uma competência comunicativa.

Esta seção buscou identificar valores epistemológicos que possam relacionar-se com a importância do desenvolvimento de um ensino de línguas cada vez mais ligado à prática comunicativa livre, autêntica, original e criativa. Além de oportunizar considerações elementares sobre as teorias fundamentais a esta pesquisa, buscamos aqui também prover aos leitores com reflexões sobre a CC e algumas pesquisas indispensáveis sobre a ASL ou a ALE, dado que ambos os modos de aquisição linguística são relativamente similares, principalmente no mundo globalizado e telecomunicativo atual. Não foi então objetivada uma apresentação aprofundada e minuciosa sobre cada construto, senão servir aos professores e alunos com uma visão mais panorâmica dos principais estudos sobre aquisição linguística que foram considerados na construção dos princípios teóricos nos quais está embasado no capítulo Análise e Discussão de Dados. 



\section{METODOLOGIA}

\subsection{INTRODUÇÃO}

Neste capítulo apresentamos os fundamentos, objetivos e características metodológicas desta pesquisa-ação, de caráter qualitativo, que buscou encontrar no ambiente de estudo dados relevantes que possam fortalecer as assertivas apresentadas sobre a necessidade de maior presença dos modos modernos de comunicação e das artes no ensino de línguas em geral. Tal procedimento confere um aspecto militante à pesquisa, com o modesto intuito de que possam servir como referências de usos para os demais educadores em geral, considerando que muitos dos temas abordados vão ao encontro de toda a dinamicidade e complexidade do ensino e aprendizagem.

Baseado primeiramente na visão de Lewin (1951) - que distingue quatro categorias de pesquisa-ação (Diagnóstica, Participativa, Empírica e Experimental), de acordo com sua natureza e objetivos (ADELMAN, 1993, p. 13-14), ou seja, sem a preocupação de adequar-se à pesquisa-ação integral de Morin (2004) - esse trabalho buscou primeiramente diagnosticar alguns problemas que os Centros Interescolares de Línguas (CIL) têm enfrentado para formar alunos fluentes na língua em estudo e, por meio da participação docente, recomendar medidas para remediá-los, pois nesse tipo de pesquisa seus autores encontram-se reciprocamente implicados aos atores sociais (DESROCHE, 2006).

Dessa forma e como partes integrantes desse capítulo, apresento os seguintes tópicos: a) a natureza dessa pesquisa, visando situar o leitor sobre seu objeto de estudo, objetivos e perguntas de pesquisa, bem como seu contexto; b) características e demais considerações sobre a pesquisa qualitativa; c) considerações sobre a pesquisa-ação e seus tipos mais comuns; d) os instrumentos de coleta de registros e análise de dados; e) aspectos éticos relacionados à pesquisa e o processo de escrita dessa dissertação.

\subsection{NATUREZA DA PESQUISA}

Tendo em vista que para resolver um problema é imprescindível conhecê-lo, este trabalho visou investigar como os professores dos Centros Interescolares de Línguas de Taguatinga (CILT) e Ceilândia (CILC) têm utilizado ferramentas digitais atualmente disponíveis para superar dois problemas observados nesses loci de pesquisa e que têm dificultado a aquisição linguística: a inviabilidade de ampliação da carga horária dos cursos e o pouco contato dos alunos com a língua alvo em seu cotidiano, entre outros descritos no 
capítulo de Análise e Discussão de Dados. Ao defender maior presença das ferramentas digitais e de atividades artístico-pedagógicas no ensino de línguas para promover maior contado dos estudantes com a língua alvo, esta pesquisa adquire um caráter militante, buscando em seus registros dados teóricos e práticos relacionados às características laborais dos professores que se utilizaram de alguma ferramenta digital como recurso complementar ao ensino e que nela participaram como informantes, reforçando algumas assunções préexistentes ou ampliando o conhecimento desta causa.

Para tanto, foi feita uma pesquisa-ação diagnóstica nesses centros de línguas visando conhecer melhor os desafios enfrentados pelos professores e quais ferramentas foram por eles utilizadas para superá-los ou quais se demonstraram potencialmente expressivas, respondendo, principalmente, às duas perguntas abaixo:

1) Qual a importância das atividades de produção oral e escrita através dos meios modernos de comunicação e suas ferramentas para o ensino/aprendizagem de línguas?

2) Quais ferramentas têm sido mais facilmente absorvidas pelos professores de línguas nas escolas estudas para promover maior contato dos estudantes com a língua alvo e quais são consideradas como potencialmente relevantes para esse fim?

Esta pesquisa visou ainda, por meio das estratégias de coleta de registros e análise de dados descritas neste capítulo, um desenvolvimento e aprofundamento teórico sobre a importância da produção oral e escrita para o ensino de línguas, aliado a um desenvolvimento de diretrizes e exemplos que possam nortear os professores no uso de tecnologias modernas de comunicação, ligando-as às artes audiovisuais, visto que elas também são modos genuínos de comunicação, e listando quais recursos demonstram ser mais efetivos ou viáveis.

Em suma, participaram diretamente dessa pesquisa mais de cinquenta professores, ora pela participação em debates e exposições da pesquisa, ora pelos relatos aos questionários de pesquisa. Dentre eles cinco deles foram escolhidos para participar de entrevistas com o intuito de coletar maiores informações sobre suas experiências com o uso de ferramentas digitais no ensino, uma vez que estes informantes já possuíam notável reconhecimento nos loci de pesquisa devido a inovações promovidas para buscar ampliar o contato que os alunos mantêm com a língua em estudo e desenvolver mais suas habilidades criativas por meio da produção oral e escrita. Participaram também, de forma indireta, todos os agentes escolares e 
alguns alunos de modo a possibilitar meu acesso livre às instituições e a execução das estratégias de coleta de registros aqui descritas, sem prejuízos à rotina escolar.

\subsection{A PESQUISA QUALITATIVA}

Diferentemente da pesquisa quantitativa que, a partir de uma lógica positivista, emprega métodos experimentais aliados a medidas relativamente exatas para testar hipóteses, a pesquisa qualitativa parte de uma abordagem naturalística para buscar entender um fenômeno e não tenta manipular o fenômeno de interesse (PATTON, 2002). Strauss \& Corbin (1990) consideram qualquer estudo que não se baseia em estatísticas e dados quantitativos como qualitativo. Ao proceder com um estudo por meio de entrevistas e observações, entre outros métodos, o pesquisador precisa fazer uma interpretação dos resultados, dando um caráter subjetivo à pesquisa. Nesse tipo de abordagem o pesquisador se envolve com a pesquisa e seu objeto de estudo de uma forma mais próxima e duradoura.

Se, por um lado, nos estudos quantitativos é necessária uma instrumentalização para testar projeções diversas, por outro, nos estudos qualitativos o pesquisador é o instrumento (PATTON, 2002) e precisa defender suas assertivas considerando os dois lados da moeda, ou seja, a partir de uma perspectiva holística. Dessa forma, a evolução do conhecimento em pesquisa qualitativa se da pela contestação, ou mesmo confirmação, de assunções anteriores pelos novos pesquisadores, a partir de novos dados, interpretações ou observações.

Entretanto, ambos os estudos não são necessariamente excludentes. São possíveis abordagens mistas, em que estratégias interpretativas e experimentação empírica andam lado a lado, dado que cada uma produz um resultado particular, ou mesmo a consideração de um estudo quantitativo na construção de um texto interpretativista, pois até mesmo os dados quantitativos precisam ser interpretados. Porém, a validação de uma pesquisa qualitativa se dá por meios distintos e é recorrente uma relativização desse processo.

Nesse tipo de pesquisa, termos como validação e confiabilidade, a pesar de estarem no rol de preocupações da pesquisa qualitativa, costumam não ser tão adequados, pois as características que permitem que ela seja generalizável são de natureza subjetiva e contextual. Para garantir-lhe maior credibilidade os pesquisadores têm usado de artifícios como o uso de distintos métodos e estratégias para obter dados relevantes: a triangulação, ou a cristalização que, apesar de ser menos empregada, pode enriquecer o estudo provendo-o com modos de compreensão de cada face de um problema ou fenômeno. 
A partir de uma perspectiva construtivista, vemos que todos esses artifícios são válidos e podem contribuir para uma maior compreensão dos contextos socioculturais e fenômenos diversos, aliando-me à visão de Johnson (1995), que considera que em qualquer pesquisa qualitativa o alvo é "acoplar uma pesquisa que prova por um entendimento mais profundo do que um exame superficial das características". Também, Johnson (1997) reconhece que um pesquisador qualitativo pode usar triangulação investigativa e considerar as ideias e explanações geradas por pesquisadores adicionais estudando os pesquisadores participantes. Tais características ampliam o modo como vemos a ciência, pois a maioria dos estudos são feitos sob limitações múltiplas e a história nos ensina que os avanços têm sido feitos de maneira gradual, à medida que cada pesquisador se apoia nos ombros uns dos outros, semelhante à célebre frase atribuída a Isaac Newton: "Se eu vi mais longe, foi por estar sobre ombros de gigantes".

\subsection{A PESQUISA-AÇÃO}

A pesquisa-ação, termo cunhado por Lewin em 1944 para referir-se aos processos reflexivos de solução progressiva de problemas que já vinham sendo usados alguns anos antes, é o tipo de pesquisa que não separa a investigação da ação necessária para resolver um problema (MCFARLAND \& STANSELL, 1993, p. 14), ou seja, nessa modalidade de pesquisa há uma relação sine qua non entre o estudo e sua utilidade prática, buscando na resolução dos problemas observados sua razão de ser. Isso demanda do pesquisador mais do que apenas considerações unilaterais sobre um problema, senão uma busca contínua de identificação das dificuldades e contextualidades que têm impedido sua resolução. Nessa modalidade não basta formular perguntas sobre o que está errado ou quais os problemas principais, mas, principalmente, fazer uma busca de conhecimento para melhorar cada vez mais as práticas que se relacionam com os problemas sociais, sem negligenciar a literatura existente, porém com o foco constante em seus equacionamentos e amenizações.

$\mathrm{Na}$ área de educação a pesquisa-ação mantém suas raízes e conceitos, porém de forma enriquecida pelas terminologias, características, deontologias e demais peculiaridades dessa área profissional. Segundo Watts (1985), a pesquisa-ação é um processo no qual cada participante examina suas próprias práticas educacionais de forma sistemática e cuidadosa, usando técnicas diversas de pesquisa e está baseada nas seguintes assunções: 
- Professores e diretores trabalham melhor sobre os problemas que eles têm identificado por si mesmos;

- Professores e diretores se tornam mais efetivos quando estão encorajados a examinar e avaliar seu próprio trabalho e então considerar formas de trabalhar diferente;

- Professores e diretores ajudam-se por meio do trabalho colaborativo;

- Professores e diretores que trabalham conjuntamente percebem avanços em seu desenvolvimento profissional.

Apesar de haver tipos plurais de pesquisa-ação (EL ANDALOUSSI, 2004), alguns processos são comuns e envolvem "planejamento não linear, ação, observação e reflexão sobre as mudanças nas situações sociais" (NOFFKE \& STEVENSON, 1995, p. 2). Isso poderia igualá-la às outras modalidades de pesquisa, caso ela não tivesse esse caráter preponderante: a cooperação entre os participantes para a criação de resultados satisfatórios e suficientes para superar as dificuldades em foco. $\mathrm{O}$ ideal é que em cada fase o pesquisador possa contar com a colaboração dos envolvidos e que os resultados sejam compartilhados com o grupo, bem como as experiências proporcionadas pela pesquisa. Contudo, essa noção colaborativa faz com que ela ganhe aspectos ainda mais desafiadores, pois o pesquisador precisa ganhar a adesão dos agentes sociais, nesse caso os professores, para que ela possa fluir e chegar aos objetivos esperados.

Enfim, assim como toda pesquisa, ela precisa encontrar embasamento teórico na literatura existente e identidade própria, uma vez que é possível que outros pesquisadores tenham abordado questões semelhantes e seria ineficiente replicar um trabalho quando se tem a oportunidade de ampliar o conhecimento de uma determinada área (MACINTYRE, 2002). Brown (1991) chama isso de "Research Extending Knowledge", ou seja, Pesquisa de Ampliação de Conhecimento e a considera algo elementar em pesquisa-ação. Essa função gera maior relevância à pesquisa e um senso de utilidade das instituições que as fomentam, à medida que a sociedade percebe progressos diversos provocados pelos estudos nos quais cada pesquisador sobe nos ombros de seus antecessores para poder ver mais longe e contribuir com o estabelecimento de um conhecimento firme e alinhado à prática, dado que esse processo tem marcado a história do conhecimento cientifico no mundo. 


\subsection{INSTRUMENTOS DE COLETA DE REGISTROS}

De acordo com Brown (1991), pesquisas feitas em pequena escala podem receber muitas críticas se as descobertas forem tão específicas que não sirvam para ninguém mais, ou seja, não generalizáveis. Por sua vez, Macintyre (2002) aponta o engajamento cooperativo na pesquisa como uma das chaves para a coleta suficiente de dados e o enriquecimento da investigação. Tais considerações demonstram um pouco o quanto essa fase da pesquisa é importante e delicada, pois as escolhas estratégicas de coleta de dados, vista aqui como termo que abarca tanto os registros crus quanto os dados selecionados, são feitas em níveis de complexidade mutáveis. As estratégias devem ser múltiplas, porém viáveis, e alinhadas aos objetivos e à duração da pesquisa, pois os desafios da pesquisa não se encerram nessa fase, obrigando o pesquisador a reservar tempo suficiente para análise dos dados e apresentação do texto final com as assertivas, considerações e resultados promovidos pela pesquisa.

Dessa forma, foram usadas as seguintes estratégias para obter informações e experiências relevantes para o cumprimento dos objetivos de pesquisa:

- Entrevistas: foram selecionados cinco professores informantes entre os principais agentes em projetos didáticos em que a presença das ferramentas digitais ou atividades artísticas foi percebida para complementar o ensino. Constituíram-se de entrevistas semiestruturadas sobre os desafios, utilidades e particularidades do processo de ensino e aprendizagem. Dessa forma, as entrevistas permitiram que o entrevistado verbalizasse seus pensamentos, tendências e reflexões sobre os temas apresentados, permitindo a identificação de valores, crenças, sentimentos, atitudes, razões e motivos acompanhados de fatos e comportamentos (ROSA \& ARNOLDI, p. 2006). Segundo Hood (2009, p. 77) esse é o método de elucidação de dados mais usado, pois pode fornecer uma riqueza de dados válidos. Nesta pesquisa foram realizadas cinco entrevistas de extensões diferentes, razão pela qual alguns professores forneceram mais regitros que outros.

- Grupos Focais: foram selecionados alguns entre os principais expoentes do uso de recursos modernos na educação nas escolas mencionadas para que, por meio de debates, os participantes pudessem revelar suas percepções sobre os tópicos presentes nessa pesquisa. Tais intervenções demonstraram-se muito úteis e vantajosas quanto 
aos custos para realização e a riqueza de registros obtidos. Seu caráter interacional permitiu também uma maior aproximação do pesquisador com a realidade da rotina do ensino e seus problemas mais desafiadores. "A marca registrada do grupo focal é o uso explícito da interação verbal”, conforme observa Morgan (1996; p. 2), ou seja, é por este meio que as considerações podem emergir de forma mais natural e sincera, sem desconsiderar a riqueza de informações que podem ser obtidas com os quatro modos básicos de comunicação não-verbal citados por Gorden (1980): proxêmicos, cronêmicos, paralinguísticos e cinésicos. Foram realizados dois grupos focais, um em cada escola para apreciar desde a relevância do tema desta pesquisa a algumas de suas acertivas.

- Portfólio: segundo Hernández (2000), o Portfólio "é continente de diferentes classes de documentos (notas pessoais, experiências de aula, trabalhos pontuais, acompanhamento do processo de aprendizagem, conexões com outros temas fora da escola, representações visuais, dentre outros) que proporciona uma reflexão crítica do conhecimento construído, das estratégias utilizadas e da disposição de quem o elabora em continuar aprendendo". Portanto, foi criado um portfólio virtual listando as ferramentas disponíveis e como elas podem ser usadas para enriquecer os cursos e superar os desafios mencionados nessa pesquisa, assim como amostras de trabalhos, projetos e performances que foram registradas como exemplos de trabalhos onde as artes e as ferramentas digitais fizeram parte das estratégias docentes para a complementação dos cursos. O portifólio desta pesquisa está disponível digitalmente no endereço indicado no Apêndice I.

- Notas de Campo: foram tomadas notas sobre os aspectos e informações mais importantes que pudessem ser úteis na construção textual da pesquisa. Artifício comum da etnografia, as notas de campo são registros dinâmicos e imediatos que conferem ao pesquisador uma possibilidade de registro das impressões momentâneas para posterior análise. Johnstone (2000, p.58) já reconhecia a importância de uma observação sistemática de vários elementos da interação. Dentre eles podemos citar o cenário, os participantes, os objetivos, a sequência de atos, o tom (humor) do evento, os instrumentos utilizados, as normas e o gênero (tipologia do evento). As notas de campo foram tomadas em todas as visitas às escolas, observando aspectos institucionais e algumas FD utilizadas nos projetos didáticos. 
- Observação Participante Assistemática: foram observadas as dinâmicas, cronogramas e planejamentos escolares, bem como aulas e atividades diversas de modo a poder absorver mais detalhes sobre a prática docente e discente. A observação participante, de acordo com Haguette (1992, p.35), é uma técnica de coleta de dados menos estruturada, oriunda da Antropologia, a partir dos estudos de Malinowski, e da Sociologia, na década de vinte, com a Escola de Chicago. Alvarez (1991), por sua vez, reconhece essa observação como "único instrumento de pesquisa e coleta de dados que permite informar o que ocorre de verdade na situação real", alinhando-se à necessidade de compreender de forma completa uma cultura local e seus aspectos não conscientes ou não assumidos.

\footnotetext{
"A observação participante é talvez de maior importância por ser crucial para o desenvolvimento do entendimento de uma cultura. Richards (2003) lista quatro componentes principais que os observadores deveriam fazer um esforço consciente para anotar: o cenário (espaço e objetos), os sistemas (procedimentos), as pessoas e os comportamentos. À primeira vista, será provavelmente difícil saber em que focar em sua observação" (HEIGHAM; SAKUI, 2009, p. 96).
}

Portanto, essa pesquisa buscou focar principalmente nas práticas de ensino/aprendizagem dos informantes, porém sem desconsiderar os demais componentes relacionados ao ensino nas escolas mencionadas.

Questionários: foram feitos questionários com questões pertinentes à pesquisa, como quais ferramentas têm sido mais usadas, visões sobre o ensino moderno de línguas, desafios encontrados, resistência à tecnologia, etc. Foram utilizadas questões abertas e fechadas, de acordo com as considerações de Manzato \& Barbosa Santos (2012):

\footnotetext{
"Um questionário deve obedecer a algumas regras básicas onde o principal é que possua uma lógica interna na representação exata dos objetivos e na estrutura de aplicação, tabulação e interpretação. A primeira parte do questionário exige a identificação de quem faz a pesquisa: nome da empresa, entrevistador, crítico, supervisor, para compor o controle de dados, bem como o seu número (em geral questionários são numerados). Em seguida se exige a identificação do entrevistado com nome, endereço, sexo, faixa etária, profissão etc. (dependendo dos objetivos do estudo). Quase sempre são colocados "filtros" eliminatórios nos questionários. São chamados "filtros" aquelas questões que selecionam o universo a ser pesquisado e organizam os entrevistados segundo características impostas pelo estudo (...)”.
} 
Esta fase de coleta de dados teve caráter exploratório, ou seja, buscou proporcionar maior familiaridade com o problema para torná-lo explícito e embasar a construção das assertivas, além de envolver um levantamento bibliográfico e entrevistas com pessoas que vivenciaram o problema pesquisado. Para tanto, foi feito o uso da espiral simplificada de pesquisa-ação, em que as ações e reflexões sobre o contexto problemático se intercalam, sem desconsiderar as fases de planejamento e observação, de modo a proporcionar ao pesquisador embasamentos generalizáveis que possam servir como referência para demais pesquisadores, professores e instituições.

\subsection{SOBRE A ANÁLISE DE DADOS}

A análise de dados é um processo que pode acontecer ainda em campo ou após a coleta dos registros (BOGDAN, 1991) e consiste em uma seleção dos registros mais relevantes e sua organização com vistas a identificar padrões ou dividi-los em categorias manipuláveis, bem como o estudo do que e como serão apresentados. É essa análise que conduz os dados para o produto final da pesquisa e é vista como parte importante da pesquisa. Strauss (1987; p. 286) considera que "nenhuma proposta deveria ser escrita sem uma prévia coleta e análise de dados", evidenciando que essa análise é uma espécie de termo de conduta ética na pesquisa, pois pouca dedicação a ela pode desvirtuar tal pesquisa, mesmo que os dados coletados sejam de boa qualidade.

Contudo, a análise não precisa ser sistematizada de forma a engessar o direito de escolha de quais dados são mais relevantes, viáveis ou úteis para o pesquisador. Bogdan (1991) alerta sobre o fato de persistir ainda uma tendência tradicionalista de formalização dessa análise, apesar de alguns pesquisadores pós-modernos defenderem uma abordagem mais criativa, aberta e experimentalista. Isso demonstra que também essa fase da pesquisa pode ter caráter subjetivo e idiossincrático, uma vez que o pesquisador pode atentar-se somente aos dados que lhe convém, pois em toda pesquisa há uma necessidade de estreitamento dos objetivos ou visões estratégicas que interferem no modo de tratá-los, triangulá-los ou apresentá-los.

A análise dos dados sendo feita a partir das diversas estratégias supracitadas demonstra uma intenção de triangulação metodológica, conforme realizado neste trabalho. Patton (2002) defende o uso da triangulação indicando-a como um estudo de combinação de métodos, podendo significar um estudo de vários tipos de métodos ou dados, incluindo o uso tanto de uma abordagem quantitativa quanto qualitativa, ou seja, apesar de cada estratégia 
suprir a objetivos distintos elas não são excludentes, senão complementares para que possam contribuir com a confiabilidade e validação da pesquisa. Tais atributos são obtidos por meio da convergência dos resultados e observações. É uma forma de demonstrar por meio de múltiplas vias que os argumentos são consistentes ou mesmo provar por meio de exemplos práticos a existência de um fato ou atitude recorrente, conforme postulado por Campbell \& Fiske: "A validação é tipicamente convergente, uma confirmação por meio de processos de mensuragem independentes" (CAMPBELL \& FISKE 1959, p.81).

Em face a estes preceitos, esta pesquisa utilizou-se dos registros plurais que puderam ser analisados de forma a coletar informações e exemplos que pudessem dialogar com as assunções do pesquisador e refletir um caráter contemplador das vozes dos professores informantes, pois estes puderam expressar seus anseios, ideias e inquietações ao participarem desta pesquisa. Dessa forma foi possível enriquecer a pesquisa à medida que os próprios professores puderam expor algumas de suas visões sobre suas necessidades imediatas no processo de ensino/aprendizagem e indicar possíveis soluções parciais para os problemas inerentes ao ensino de línguas em contexto ímpar, como é o caso desse ensino no Brasil, onde colocar-se em comunicação nos idiomas estrangeiros é consideravelmente mais difícil do que em alguns outros países.

A partir de então foram organizadas as contribuições e demais informações de modo a tecer um texto gradual e com certa completude quanto à profundidade de análise sobre quais os principais problemas que obstam o contato diário dos alunos com a língua alvo, quais ferramentas demonstram significativa utilidade para promover o uso linguístico em atividades extraclasse e quais projetos figuram-se como expoentes de sucesso na tarefa de fomentar o uso linguístico através de APA. Ainda, tais registros foram apresentados conforme as convenções temáticas eleitas pelo pesquisador de modo a poder dialogar com alguns deles sem perder de vista o intuito utilitário que esta pesquisa se propõe para servir aos professores e demais interessados com dados advindos tanto da teoria como da prática e capazes de inspirar projetos didáticos futuros.

\subsection{ASPECTOS ÉTICOS}

Vista como normas relativas aos procedimentos considerados corretos e incorretos por um determinado grupo (BOGDAN, 1991), a ética é um princípio-chave para a inserção do pesquisador no ambiente em estudo. Considerando as possíveis diversidades e peculiaridades 
locais, a preocupação ética demanda que o pesquisador esteja munido não somente dos princípios éticos universais, mas também das informações e regras institucionais e pessoais, bem como observar os modus operandi de cada grupo e ter uma postura cautelosa em cada iniciativa, sem negligenciar as questões referentes às características intrínsecas de cada profissão.

Além dessas questões deontológicas, sejam explícitas ou implícitas, o pesquisador deve considerar alguns aspectos éticos imprescindíveis para o êxito e o bom andamento da pesquisa. Bogdan (1991) considera duas questões pertinentes no panorama da pesquisa moderna: o consentimento informado, que permite aos sujeitos aderirem conscientemente e voluntariamente à pesquisa, e a proteção dos sujeitos contra qualquer espécie de danos, que por sua vez impede que os sujeitos sejam expostos a riscos superiores aos ganhos que possam advir. Itens como a proteção à identidade, o respeito, comportamento apolítico, cuidado com as informações, acordos pessoais realistas, etc., devem estar presentes no que podemos chamar de lista de checagem ética (ethic check list), como uma forma de escudo do pesquisador para colocar-se no campo de pesquisa. Também, a fidelidade aos dados é algo imprescindível para a confiabilidade da pesquisa, porém o cuidado ao apresentá-los é ainda mais importante.

Não obstante, esse autor cita que muitos pesquisadores alertam para o fato de a relação entre o sujeito e o investigador ser mais duradoura nos estudos qualitativos (CASSELL, 1978; CASSELL E WAX, 1980; PUNCH, 1986). A relação entre ambos é mais parecida com uma relação de amizade do que propriamente investigativa e não se pode desconsiderar a possibilidade de choques de visões, princípios ou mesmo entre as obrigações como cidadão e como pesquisador. É possível que o pesquisador perceba casos de injustiça, corrupção e distorções de comportamento, obrigando-o a estar constantemente reavaliando qual a medida certa a tomar em cada situação. Tudo isso coloca a ética como questão frequente e relevante no campo de pesquisa e o pesquisador precisa estar atento a essas diversas questões para que possa efetuar seu trabalho da melhor maneira possível e não deixar que possíveis problemas subjetivos possam desviar o curso da pesquisa, porém sem abster-se de suas responsabilidades como cidadão.

Assim sendo, esta pesquisa observou aos aspectos éticos supracitados, priorizando pela manutenção do sigilo das identidades, exceto quando considerou relevante a menção dos informantes e se obteve sua anuência. Nestes casos foram firmados termos de consentimento junto a esses participantes. Também, toda a coleta de registros e intervenções respeitaram as normas, calendários, horários e procedimentos indicados pelas instituições para que 
ocorressem de forma a interferir o mínimo possível nos andamentos e trâmites escolares. Finalmente, foram extraídas das contribuições dos informantes apenas as manifestações de caráter profissional e que pudessem ser aproveitadas nesta pesquisa para evidenciar algum tópico de pertinente discussão.

\subsection{PROCESSO DE ESCRITA}

Por estar inserido de forma ativa em um ambiente de pesquisa em que possuo considerável experiência e participação nas atividades didáticas, uma vez que é também o local onde tenho podido executar a docência e realizar inúmeros projetos didáticos, foi concebida naturalmente uma perspectiva êmica sobre as complexidades referentes ao ensino de idiomas nos CIL. Tal perspectiva, que é ponto central da maioria das pesquisas etnográficas, se caracteriza por uma visão não alheia ao contexto sociocultural do objeto de pesquisa, ou seja, o observador se coloca em situação complacente, convivente e compassiva em relação ao grupo em estudo, permitindo-lhe compreender melhor por que membros de um grupo social fazem o que fazem (FETTERMAN, 1998). Ainda, este autor considera tal perspectiva como útil para o reconhecimento e aceitação de realidades múltiplas por ser crucial para compreender o modo de pensar e agir dos indivíduos.

A partir de então, foram perseguidos nesses centros de línguas os principais empecilhos para a aquisição linguística em nível mais alto e defendidas medidas e abordagens interdisciplinares e multidisciplinares para a criação de um ambiente propício ao ensino e aprendizagem moderno, isto é, inserido nos modos modernos de comunicação e telecomunicação. Tudo isso sem negligenciar a importanância de a pesquisa-ação contemplar a voz dos pesquisados, conforme Franco (2005) defende: “a pesquisa-ação crítica considera a voz do sujeito, sua perspectiva, seu sentido, mas não apenas para registro e posterior interpretação do pesquisador: a voz do sujeito fará parte da tessitura da metodologia da investigação". Portanto, foi objetivada a manutenção o mais integralmente possível das falas dos principais informantes desta pesquisa, atentando-se ao comentá-las apenas aos pontos considerados como mais relevantes aos seus objetivos.

Dessa forma, ensejamos um texto auspicioso, que possa servir aos demais profissionais da área de ensino como referência e suporte na promoção de maior presença das novas tecnologias e das artes em geral no âmbito escolar, de modo a criar uma espécie de semi-imersão linguística ou pelo menos um ambiente em que os alunos possam vivenciar de 
forma mais prática o conhecimento adquirido. Ainda, esperamos ter tratado de questões gerais do processo de ensino/aprendizagem que figuram como desafiadoras nas redes de ensino público, como questões de autonomia, didática e ensino empoderador e transformador defendido pelos grandes educadores modernos, entre os quais se destaca Paulo Freire (1992).

Finalmente, é válido destacar que, devido às limitações desta pesquisa, optamos por enfatizar na análise apenas alguns trechos dos dados coletados, ainda que o texto pudesse oportunizar inúmeras outras considerações. Tal opção seguiu valores e princípios idiossincráticos e estratégicos da pesquisa e do pesquisador que nos impeliram a ater-nos mais ao sentido geral dos excertos do que responder a cada manifestação dos informantes de forma completa. Os resultados foram compilados e apresentados no próximo capítulo, Análise e Discussão de Dados, seguindo conveniências que visaram à construção de um texto que pudesse ao mesmo tempo evidenciar alguns valores e vantagens observados e permitir uma apresentação textual gradual que facilite o entendimento de que, apesar de estarem dispostas separadamente, todas as considerações estão interligadas, pois as análises referentes um item em foco podem ser extensíveis ao outros. 



\section{ANÁLISE E DISCUSSÃO DOS DADOS}

\subsection{SOBRE A IMPORTÂNCIA DAS FERRAMENTAS DIGITAIS PARA O ELE}

A importância do uso de ferramentas digitais para aperfeiçoar e modernizar o ensino pode parecer óbvia para muitos educadores, principalmente para os que já utilizam tais recursos por tempo suficiente para perceber suas potencialidades. Todavia, a emersão de novas tecnologias tem estado frequentemente associada a intensas transformações sociais nos modos de comunicação e informação. Os meios eletrônicos de informação, por exemplo, já são os principais instrumentos de acesso ao conhecimento do mundo moderno (LEVY, 1999) e a comunicação experimenta formas mais rápidas, dinâmicas e práticas de intercâmbios semânticos e de propostas interacionais.

Entretanto, as vantagens advindas do uso criativo das ferramentas digitais disponíveis precisam ser melhor conhecidas pelos professores de línguas, uma vez que ainda é percebida grande resistência no âmbito educacional à sua inserção em propostas didáticas que visam envolver mais os alunos e oportunizar-lhes maior contato com a língua em estudo. A ignorância do quão proveitosas possam ser essas ferramentas para auxiliar os alunos a absorverem insumo e produzirem materiais comunicativos pode levar a um receio de que elas aumentem a carga de trabalho desses profissionais, desprezando o fato de que o real responsável por esse possível incremento laboral está relacionado mais ao modo e à expertise de uso da ferramenta do que a ela em si própria.

Além do desconhecimento dessas vantagens, esta pesquisa identificou também outros motivos que podem levar os professores a adiarem sua experimentação das atividades e ferramentas propostas, como pode ser observado nas respostas de alguns professores, sob nomes fictícios, à pergunta "Como você vê a importância do uso de ferramentas digitais para envolver os alunos em projetos de produção audiovisual para a aprendizagem de língua estrangeira?", transcritas a seguir:

\footnotetext{
"Acredito que o uso de ferramentas digitais é muito importante para envolver os alunos e para facilitar a aprendizagem de língua estrangeira, porém não é o único meio. Muitos se importam tanto com o uso de ferramentas digitais que acabam esquecendo que há outras ferramentas de ensino tão eficazes quanto as ferramentas digitais. Essas ferramentas, sem dúvida, contribuem bastante no planejamento da aula e durante as explicações de conteúdos gramaticais e vocabulário, otimizando o tempo e a compreensão dos alunos. É possível também desenvolver projetos bastante criativos com os alunos e, muitas vezes, muito mais motivadores para a aprendizagem de língua estrangeira" (profa. Alice).
} 
“A ideia em si é ótima, mas o desenvolvimento do projeto é difícil. A atividade demanda tempo, principalmente em sala de aula e necessita de grande atenção e envolvimento também do docente. Se a atividade for desenvolvida sem esta atenção pode acabar se tornando um trabalho escolar a mais sem grande significado. Também é importante o feedback dos trabalhos prontos e a valorização do produto final como formas de maior incentivo para a atividade" (profa. Bianca).

"Tudo aquilo que possa envolver o aluno fazendo com que aprenda mais é interessante, embora haja uma resistência dos professores por não dominarem a área de T.I (Tecnologias da Informação)” (prof. Cesar).

"De fato existe uma certa evolução, principalmente no que diz respeito à aquisição de vocabulário específico utilizado em cada produção. Contudo, nem todos os alunos têm interesse na atividade, dado à carga de trabalhos acadêmicos ou ao simples desinteresse no projeto (preguiça, dificuldade de trabalhar em grupo, resistência a atividades extraclasse). Os alunos que participam ativamente do processo e se envolvem nas fases da atividade de produção têm um ganho linguístico maior do que os demais. Para os alunos que apenas realizam a tarefa para "nota" (avaliação) não existe ganho perceptível” (profa. Diana).

De fato, é desejável um domínio da ferramenta e um planejamento minucioso por parte do professor para conseguir envolver todos os alunos e não gerar trabalhos desnecessários ou pouco proveitosos que possam minar o êxito em cada atividade de produção audiovisual. Porém, os argumentos de que as ferramentas tradicionais da educação vistas por este trabalho como a lousa, os aparelhos de reprodução audiovisual, editores de texto e planilhas organizacionais, por exemplo - são suficientes e necessitam apenas ser melhor aproveitadas não condizem com a realidade do ensino de línguas no Brasil, pois ainda é percebido um enorme vão entre as práticas didáticas escolares e as necessidades modernas dos alunos.

Os argumentos de que essas atividades são onerosas à sala de aula, pois seriam difíceis e demoradas, não refletem a realidade de todas as propostas, pois o principal objetivo das ferramentas indicadas por esta pesquisa é facilitar ou aperfeiçoar os modos de produção textual ou audiovisual. O que se tem observado é que as atividades propostas, quando seguem o princípio de que didaticamente o mais importante é o processo e não o produto, têm aumentado o interesse e o uso legítimo do idioma. Também é possível que essas dificuldades sejam sentidas pelo não domínio da ferramenta escolhida, por isso recomenda-se que o professor avalie bem cada proposta didática para prever sua viabilidade e busque conhecer suficientemente cada ferramenta para utilizá-la com mais desenvoltura.

$\mathrm{O}$ preponderante é que, à medida que percebe as vantagens que as atividades e ferramentas digitais podem oferecer para fomentar o cumprimento de seus objetivos didáticos, o professor pode engajar-se de forma mais segura, ciente de que os esforços relacionados a 
cada uma valem a pena, pois estimulam a autonomia entre os alunos e criam um ambiente mais favorável à aquisição, retirando de seus ombros um pouco da carga de responsabilidade pelo nível de aquisição dos alunos. Além disso, não podemos esquecer que muitas ferramentas se propõem justamente a substituir algumas práticas escolares automatizadas, gerando maior tempo para uso da sala de aula para a aquisição linguística, conforme Krashen (1985) aconselhava.

Para conhecer melhor a utilidade dessas ferramentas e quais atividades podem suprir as necessidades comunicacionais dos cursos precisamos refletir mais sobre os principais problemas relacionados ao ainda modesto sucesso dos alunos brasileiros no domínio das línguas estrangeiras. Foi diante deles que a principal assertiva desta pesquisa foi pensada, pois constatamos que a produção audiovisual qualifica o insumo recebido à medida que a experimentação linguística genuína gera nos alunos maior confiança comunicacional, ou seja, os alunos conseguem se expressar com maior segurança ao se basearem em experiências de êxito anteriormente observadas.

Dessa forma, apresentamos a seguir uma lista dos fatores que consideramos mais prejudiciais ao ensino de línguas no Brasil (criada a partir das observações assistemáticas e dos grupos focais mencionados no capítulo metodológico) e reflexões sobre os desafios a serem superados para que os estudantes de línguas possam engajar-se em interações linguísticas mais relevantes e absorver mais insumo, otimizando-o com sua produção.

a) Carga horária insuficiente: muitos professores alegam que a média semanal de 2h40min de aulas nos cursos dos CIL, semelhante à média de muitas outras escolas, é insuficiente para "trabalhar o conteúdo" e atribuem a ela a responsabilidade pelo ainda insatisfatório êxito educacional. Porém, o aumento da carga horária assíncrono a uma mudança significativa nas estratégias didáticas pode ser ineficiente, além de ser praticamente inviável, devido a fatores financeiros e estruturais. O caminho mais adequado parece ser mesmo uma busca de maior efetividade dos esforços didáticos. Lévy (2000) também percebe dessa forma ao reconhecer a necessidade de buscar soluções para ampliar o esforço pedagógico dos professores por meio do uso de tecnologias digitais, já que a flexibilização dos cursos diante das possibilidades e necessidades dos alunos é uma tendência do ensino em geral.

b) Inabilidade das atividades extraclasse em submeter os alunos a absorverem insumo linguístico diariamente: as atividades de extensão à sala de aula normalmente resumem-se a exercícios gramaticais ou lexicais, principalmente nas 
escolas estudadas. Como os alunos precisam ser guiados a tarefas que realmente lhes ajudem a praticar a expressão oral, tais exercícios não lhes têm indicado que o contato com a oralidade é crucial para a aquisição linguística. Daí a importância do uso de variados recursos de multimídia interativa, audiovisuais, técnicas de ensino à distancia, entre outros indicados por Lévy (2000). É preciso que os professores encontrem formas de proporcionar aos alunos um maior contato com a língua alvo antes mesmo de exigir-lhes atitudes autônomas.

c) Distanciamento entre o curso e a realidade dos alunos: o ensino em geral não tem a tradição de ir ao encontro dos alunos, isto é, buscar aproximar-se de suas áreas de interesse para promover maior entusiasmo e dar maior relevância às atividades propostas. Sabe-se que a valorização da realidade do aluno é ponto chave em sua motivação e interesse (STOFFEL, 2008) e, como a língua está presente em todas as atividades humanas, a contemplação das áreas de interesse dos alunos nas propostas didáticas pode estimular uma maior prática linguística alinhada a seus objetivos linguísticos pessoais. Por exemplo, ao ensinar um idioma para uma comunidade que valoriza a cultura do rap, é muito mais coerente promover uma experimentação linguística a partir das características dessa forma de expressão do que tentar impor prontamente uma apreciação literária erudita, pelo menos em um primeiro momento.

d) Relação ainda pouco dialógica entre professor e aluno: visto por Freire (1970) e muitos outros teóricos, como elemento fundamental do desenvolvimento humano e não apenas como técnica educacional, o diálogo é indispensável para a execução de projetos onde ambas as partes, orientadores e orientandos, usufruem do poder de escolha e decisão. O professor como orientador tem o poder avaliativo, gerencial e coordenativo das atividades e o aluno, ou orientando, tem em seu engajamento e em sua voluntariedade o poder de auxiliá-lo nesse processo. Bakhtin (1984) considera o diálogo aberto como a única forma adequada de expressar-se verbalmente de maneira suficiente, dado que a natureza da vida é dialógica. É através do exercício da atenção, de perguntas, respostas, concordâncias, objeções, etc., que os indivíduos podem encontrar formas mais sintéticas de executar as mais diversas atividades propostas. Portanto, nós professores ainda precisamos aprender a estabelecer um ambiente de construção colaborativa do conhecimento, fundamental para qualquer trabalho grupal, e contestar a ainda amplamente disseminada crença de que somos apenas 
transmissores de conteúdos. A autoridade que temos nos serve principalmente para escolher qual postura teremos no processo de ensino.

e) Isolamento linguístico-geográfico do Brasil: exceto os moradores próximos às fronteiras da América do Sul, no geral os brasileiros sentem muita dificuldade para visitar os países que têm o idioma em estudo como língua oficial. Em comparação com países europeus, por exemplo, onde é possível por um preço justo colocar-se em imersão linguístico-cultural e experimentar as mais genuínas práticas comunicativas, os brasileiros precisam despender de muitos recursos para vivenciar a língua em seu contexto natural. Daí a importância dos meios virtuais de telecomunicação e da criação de contextos simulados de prática comunicativo-interacional entre os alunos. Braga (2013) lembra como no passado os aprendizes de LE tinham poucas oportunidades de usar fora da sala de aula os conhecimentos linguísticos que estavam adquirindo e como as modernas possibilidades de "imersão linguística virtual" têm contribuído para a prática passiva e ativa dos idiomas. Observar isso nos faz entender que o ensino de línguas em países como o nosso é especialmente carente de estratégias didáticas que promovam momentos de uso autêntico da língua alvo.

f) Desconsideração dos filtros afetivos: apesar de estar frequentemente presente no que os professores consideram serem itens importantes para a aquisição linguística, fatores como motivação, ansiedade e autoestima, por exemplo, nem sempre são observados ao sujeitar os alunos a algumas atividades, principalmente aquelas de execução mecânica, repetitiva e pouco criativa. Essas atividades têm o poder de transformar a naturalmente prazerosa experimentação do código linguístico em algo tedioso e altamente monitorado. Em contraposição a esse tipo de atividade temos o que AUSUBEL (1978) chama de "aprendizagem significativa", que leva o aluno a integrar as novas informações e habilidades a toda sua estrutura mental anteriormente construída. Nesse tipo de aprendizagem valoriza-se mais as atividades que conseguem envolver os alunos em tarefas e desafios que realmente promovem um engajamento comunicativo enérgico e atuante, capazes de estimulá-los e desenvolver sua autoestima. É então que a experiência do professor pode auxiliar os alunos, principalmente os mais tímidos, pois saberá prepará-los antes de expô-los, evitando possíveis afloramentos de ansiedade e desinteresse, ou mostrar o caminho mais adequado para a superação das possíveis debilidades.

g) Inabilidade com ferramentas digitais: o desconhecimento dos envolvidos no processo de ensino/aprendizagem de ferramentas que possam auxiliá-los na criação, 
edição e organização das atividades comunicacionais, bem como na absorção livre de insumo compreensível, pode ser considerado atualmente como um dos fatores que mais prejudicam o ensino de línguas, dado que chegamos a um ponto em que é crucial o uso de algumas ferramentas digitais para a inclusão social dos indivíduos. $\mathrm{O}$ que Coscarelli (1998) defendeu sobre os recursos audiovisuais em uma década não muito distante e marcada pela migração de recursos analógicos para digitais hoje pode ser ampliado a muitas tecnologias digitais que dominam o cotidiano das pessoas e reconfiguram seus modos de relacionar-se:

\footnotetext{
"Os recursos audiovisuais estimulam os estudantes a desenvolverem habilidades intelectuais e de cooperação, onde mostram interesse em aprender e buscam mais informações sobre um determinado assunto. Em relação às contribuições desses dispositivos para os docentes, destacam-se: obtenção rápida de informação sobre recursos instrucionais, maior interação com os alunos e facilidade na detecção de pontos fortes e dificuldades específicas dos mesmos. Os professores começam a ver o conhecimento como um processo contínuo de pesquisa" (COSCARELLI, 1998, p. 52).
}

Ora, se os modos de acesso e distribuição do conhecimento e meios de facilitação comunicativo-interacional estão visivelmente mudados, tornando algumas práticas tradicionais obsoletas, torna-se indispensável reconhecer que os operadores da educação necessitam estar constantemente observando e respondendo a essas transformações socioculturais. Caso contrário, os profissionais correm o risco de que, conforme identificava Lévy (2000), seus conhecimentos e costumes adquiridos no início da profissão fiquem ultrapassados. Se os professores não se abrirem às novas possibilidades desse contexto moderno, empenhando-se para dominar pelo menos um pequeno conjunto de ferramentas digitais, estarão fadados ao insucesso parcial em suas proposições didáticas.

Longe de ambicionar a apresentação de uma lista completa dos fatores obstrutivos do ensino de línguas no Brasil, remetemos-nos a apresentar e comentar as impressões dos professores pesquisados em relação às vantagens observadas ao empreenderem o uso de algumas das ferramentas estudadas por essa pesquisa, tendo em vista que muitas delas têm grande potencial para auxiliar os professores na superação dos problemas citados. Em ambas as escolas (CILT e CILC) constatamos grandes interesses e esforços docentes para se inserirem no meio digital e proporcionar aos alunos atividades mais dinâmicas e interativas que possam culminar em duas mudanças capitais nas práticas e relações escolares: menor peso dos relativos êxitos e insucessos dos alunos sobre os ombros do professor, desde que ele consiga criar múltiplas oportunidades de prática do idioma e um ambiente favorável à 
aquisição linguística, mostrando caminhos possíveis para os que almejam a fluência também em um idioma estrangeiro; e, principalmente, o envolvimento dos alunos em processos de produção audiovisual consagradamente reconhecidos como práticas comunicativas autênticas, como as oficinas de escrita criativa, o teatro, a produção de vídeos diversos, atividades produção e apreciação musical, etc., assim como o uso dos sites e aplicativos de redes sociais para a coordenação dos projetos em geral.

Devido à relevância de suas contribuições a essa pesquisa e a outros fatores inerentes aos processos pesquisacionais e deontológicos, alguns informantes serão identificados e outros terão apenas suas impressões reproduzidas sob nomes fictícios. Entre eles destaca-se o trabalho do professor Gerson Moura (representando outros professores que vêm replicando atividades semelhantes a partir de sua experiência) que há mais de três anos têm promovido projetos de escrita criativa com seus alunos, apoiado pela ferramenta Storyboard (página 126), que facilita a criação de livros ilustrados.

De acordo com este professor, tal experiência é bastante proveitosa e resulta na superação de algumas debilidades linguísticas e sociointeracionais, como podemos perceber em seu relato à entrevista guiada pelo Roteiro de Entrevista (Apêndice II) dessa dissertação:

\footnotetext{
"Um trabalho que eu venho fazendo sozinho é a partir de um site chamado Storybird, em que os alunos acessam essa plataforma. Antes eu ensino como acessar, como fazer, e a proposta do projeto é que eles produzam estórias a partir de imagens. Essas imagens são doadas por artistas do mundo inteiro. São livres de direitos autorais, então não tem nenhum problema com relação ao uso delas e a proposta é de forçar a criatividade a partir da imagem que é colocada ali. Então, o aluno não escreve o texto pra depois obter a imagem. Ele tem que produzir o texto a partir das imagens que ele escolhe. Entre centenas de imagens ele escolhe as que ele acha interessante e vai montando a estória dele e produz um livro. No final do semestre essas imagens estão todas acessíveis em dois blogs. Além disso, alguns trabalhos a gente imprime, porque não da pra imprimir muito. É muita coisa. Ao longo de dois anos desse projeto a gente tem já em torno de 400 livros de boa qualidade. Livros de estórias em língua inglesa produzidas pelos alunos. Estórias desde níveis mais básicos até complexos e com diversos assuntos. No ano passado a gente focou especificamente em temas voltados para a inclusão. Então, os alunos escolheram um tema relacionado à inclusão, bullying ou qualquer tipo de preconceito. E encima disso eles produziram estórias. O retorno dos alunos tem sido bastante interessante. Hoje têm outros cinco professores que eu conheço que trabalham também esse projeto. Eu sai do Centro Línguas de Ceilândia, mas lá tem dois professores que continuam. O projeto está continuando e outras escolas. Aqui no Cento de Línguas de Taguatinga tem outra professora que achou interessante e resolveu continuar com esse projeto de produção de textos em língua inglesa. E todo esse trabalho tem que ser online. O aluno produz o livro dele, na casa dele e no tempo dele" (prof. Gerson Moura).
}

É nítido em seu relato que essa proposta didática tem sido reconhecida nas escolas por professores experientes que perceberam as potencialidades da produção criativa para auxiliar os alunos a experimentarem a prática comunicativa a partir de uma de suas funções 
linguísticas mais genuínas: a geração autônoma de sentidos. Sua opção foi pela criação textual motivada pelas imagens disponíveis no site indicado, mas essa não é a única possibilidade que ele oferece. É possível a construção de enredos tanto da forma descrita pelo informante como a partir de oficinas de escrita criativa ou atividades individuais e, posteriormente, relacionálas com as ilustrações. Isso demonstra que, apesar de sua experiência ser bem reconhecida no meio, nada impede que outros professores a adaptem a suas necessidades e valores.

Vale mencionar também que há outras ferramentas semelhantes e reconhecer que esse tipo de atividade pode ser feita sem o auxílio digital, pois bastam imagens e alguns materiais escolares comuns para executá-la, mas percebemos a importância de usar uma ferramenta assim devido a suas vantagens em possibilitar que o aluno a faça conforme sua conveniência temporal e criativa e nota-se também que isso facilita a consolidação desse projeto como proposta didática extraclasse, bem como sua posterior publicação. Observa-se ainda o desenvolvimento de outras habilidades em projetos assim:

\begin{abstract}
"É interessante porque, além da questão da autonomia que ele acaba desenvolvendo, outros valores que são desenvolvidos nesse projeto. A questão da autoestima (...) Temos muitos alunos (...). Uma mãe, por exemplo, que me procurou surpresa por que a filha era muito retraída, muito tímida, e a mãe espantada: "nossa, não sabia que ela era capaz disso". E a filha começou a ter mais facilidade em se comunicar com as pessoas da própria família, devido à confiança que ela foi desenvolvendo. Outra questão que a gente frisa na elaboração desse projeto, no processo, é a questão social. Uma vez que eles estudam línguas estrangeiras em uma escola pública, então eu sempre friso com eles a responsabilidade social que eles têm de devolver isso ao público. Se eu tive acesso a um ensino de qualidade na escola pública eu posso devolver isso pra sociedade com a produção que eu tenho na língua. Então esse é um fator. E a outra questão com relação a retorno social que eles têm que dar é que todos os trabalhos a gente coloca no formato PDF ou Power Point, em um CD. E esse material fica na biblioteca pros alunos pesquisarem. Nas escolas alguns deles falam "ah, professor, na minha escola não tem material pra a gente trabalhar a leitura em inglês". Então, se algum professor achar interessante a gente disponibiliza gratuitamente. E já teve alguns casos, como na Papuda [complexo penitenciário do distrito federal], com professores que trabalham com língua estrangeira e que têm dificuldades de acesso a material. A gente também já forneceu esses textos pra eles utilizarem. Então é um projeto que trabalha não só o desenvolvimento da língua do aluno, mas também tem o retorno social que esse aluno dá na aprendizagem da língua. $O$ que a gente tem chamado de "proposta autossustentável de ensino/aprendizagem de línguas", porque às vezes reclamam: "ah, na minha escola não têm livros, não tem material". Por que não começar a produzir esse material pelo próprio aluno? Então isso é possível e esse projeto é uma prova disso" (prof. Gerson Moura).
\end{abstract}

Seja a criatividade vista de forma platônica, um dom divino, ou aristotélica, uma capacidade humana, o fundamental é que atividades que auxiliam o aluno a desenvolvê-la contribuem muito para alavancar o autoconhecimento e sua capacidade interacional. Ao aventurar-se nelas, os alunos usam naturalmente de estratégias autônomas e, a cada 
dificuldade superada ou produção realizada, eles ganham mais autoconfiança e se sentem capazes de voos mais altos. Suas produções também servem como um meio de estabelecimento de interações à medida que suas publicações encontram o público através da internet. É então que eles encontram ideias e indivíduos afins e que percebem as vantagens da interação com leitores e escritores congêneres, pois encontram também utilidades imediatas da língua aprendida, dado o vasto mundo de possibilidades que a internet e suas ferramentas representam.

Percebemos então que a interação pode se dar em vários níveis, desde os mais concretos, representados pela interação física, aos mais virtuais, apoiados nas modernas tecnologias, e que ela está presente no cerne da educação desde os tempos mais remotos, desde o método socrático de pergunta e resposta aos métodos de ELE surgidos no século passado (ALMEIDA FILHO \& BARBIRATO, 2016, p. 47-49). Esses autores ainda complementam:

\begin{abstract}
"O reconhecimento da importância de se criarem nas aulas de LE situações de comunicação para os aprendizes não é algo novo e já era preocupação em outros períodos e métodos com nos métodos direto e audiolingual dos anos 1930 e 1970, respectivamente, no Brasil. Naqueles contextos tal reconhecimento estava diretamente ligado ao objetivo de otimizar o tempo de fala do professor na aula para permitir máxima produção por parte dos alunos (...). Porém, esse aumento puro e simplesmente da quantidade de fala do aprendiz não resultou necessariamente no aumento da qualidade de interação (...). A partir disso, os esforços investigativos passaram a focalizar uma questão mais complexa: ao invés de colocar os alunos para simplesmente falar entre si, o objetivo passou a ser o de engajar os aprendizes num processo comunicativo significativo (no sentido de AUSUBEL, 1968) voltado para a negociação de sentido em tópicos envolventes para os aprendizes".
\end{abstract}

Diante de tais tendências, notamos que as utilidades dos projetos de produção audiovisual não se restringem à aprendizagem individual, conforme o exemplo citado pelo informante, em que houve uma comunicação entre os escritores e outros estudantes, ou a um mero aumento quantitativo da interação entre os alunos. Há muitos outros fatores, previsíveis ou não, que emergem quando os indivíduos se propõem a construir juntos um produto final original. A aprendizagem colaborativa é um dos principais, mas vale citar também que as construções coletivas são naturalmente mais proveitosas para uma comunidade ou grupo, pois os conhecimentos e superações são mais compartilhados e os projetos tendem a crescer mais qualitativamente.

Quando os projetos amadurecem percebe-se que o trabalho de um auxilia ou inspira o outro, criando um ciclo virtuoso capaz de fazê-lo ter vida própria e até mesmo independer da constante coordenação do professor. Percebe-se também o aumento do interesse de outros 
professores em replicar esses projetos de sucesso, além de outros desdobramentos, como o registro citado do que o professor chama de "proposta autossustentável de ensino/aprendizagem de línguas". Uma proposta assim pode sofrer muita resistência e até mesmo perseguições, já que a produção dos alunos não apresenta a mesma expertise dos consagrados institutos elaboradores de material didático, porém, se virmos pelo lado da livre experimentação e consumo linguísticos, podemos deduzir que os ganhos são muito maiores do que as possíveis reproduções de desvios linguísticos por parte dos alunos que esse tipo de atividade favorece, conforme podemos observar no excerto a seguir.

\begin{abstract}
"Na verdade a dificuldade do professor muitas vezes é maior que a do aluno nesse sentido, mas a do aluno às vezes nem tanto (...). Por exemplo, em outro projeto que venho trabalhando com histórias em quadrinhos eu tive, no semestre passado, uma aluna do EJA, uma senhora de quase 50 anos de idade, que têm pouquíssimo acesso à internet e ela nunca tinha usado ou usou pouquíssimo. Então eu sentei com ela. Foi a aluna que eu tive maior dificuldade. Mesmo assim eu sentei com ela em um momento e em apenas um encontro sentamos e tirei algumas dúvidas dela com relação ao acesso e em meia hora ela criou uma história em quadrinhos em inglês. E a gratificação dela foi até interessante, porque ela saiu pulando de alegria dentro do laboratório e falando pros alunos que estavam em volta: "nossa, isso é muito bom". Vocês têm que fazer isso também". Ela saiu altamente motivada com aquilo ali. E quase sempre quando a gente encontra um problema técnico que a gente não tem a resposta tem sempre um aluno que a tem. Às vezes você realmente tem uma dificuldade com problemas que surgem com o uso da internet e os alunos geralmente acham um outro caminho. Normalmente eu deixo em aberto. No semestre passado eu propus quatro sites de produção de quadrinhos e deixei aberto: "se alguém conhecer algum outro (...)". E um aluno do sexto ano indicou uma outra: "não professor, eu trabalho com essa aqui que eu acho mais interessante". E acabou que os outros alunos acharam mais interessante a proposta dele de plataforma e fizeram também. Então os alunos na verdade têm sim alguma dificuldade, mas nunca é nada que não possa ser superado. E a aprendizagem vai ser sempre assim. Se a gente não tiver o que superar não temos o que aprender. Superar é inerente à aprendizagem. Não só com tecnologias. Mesmo só com o livro didático vai ter sempre um aluno que não vai saber responder algum exercício, que não vai saber como executar algo, pois isso é parte da aprendizagem" (prof. Gerson Moura).
\end{abstract}

Essa florescente motivação dos aprendizes é frequentemente observada em atividades de produção audiovisual (APA), principalmente quando o professor abre espaço para uma negociação do que e como fazer. É ela o combustível para a superação das dificuldades citadas e, por fomentar o engajamento discente, não é rara a postura mais colaborativa dos alunos, chegando alguns a tomar a frente dos projetos e propor novas soluções, ideias e possibilidades, assim como a experiência descrita pelo professor. Ele também descreve casos em que até os pais dos alunos se envolveram nas atividades apresentando produções próprias e que a própria publicação dos livros serviu de registro 
avaliativo. E quanto a sua avaliação diacrônica das experiências apresenta uma reveladora percepção sobre modos ainda muito mecanizados de ensinar e aprender que a sociedade têm conservado:

\begin{abstract}
"Interessante que a gente vai fazendo a avaliação ao longo do processo e depois. Então, tenho percebido que na verdade a dificuldade deles é muito mais no processo criativo que foi bloqueado em um dado momento. Eles se habituaram a repetir respostas. Eles estão acostumados com aqueles drills, com aquele sistema de ensino em que o professor treina uma pergunta e o aluno repete. Então, quando você dá uma situação em que eles têm que produzir um texto autêntico, que eles têm que criar algo, eles no início têm essa dificuldade, mas não é uma dificuldade com a tecnologia. É uma dificuldade mais com a produção em si, mas como ele [o aluno] já é um sujeito criativo ele se supera logo" (prof. Gerson Moura).
\end{abstract}

Esse bloqueio se dá provavelmente pela ainda pouco disseminada prática de aprendizagem criativa, fazendo com que muitos estudantes sintam dificuldade de ver o código linguístico como um agrupamento de possibilidades. Logo, a língua tende a ser vista como uma equivalência de expressões ímpares, como em um ping pong de palavras e expressões singulares que devem ser memorizadas tal como lhes foram apresentadas, dando pouca margem para a investigação de sinônimos e paráfrases que possam adequar-se ao contexto interacional. Consequentemente, no lugar de uma aprendizagem mais significativa, em que o descobrimento linguístico é valorizado, encontramos uma aprendizagem meramente mnemônica que busca por fórmulas prontas, como se os signos não se submetessem às circunstâncias de uso. Crentes de que as atitudes de "copiar e colar" possam fazê-los suficientemente exitosos na comunicação real.

Também para Ausubel (1963), a aprendizagem significativa é o modo ideal para adquirir e armazenar ideias e informações presentes em qualquer campo de conhecimento. Ela se caracteriza principalmente pela não arbitrariedade e pela substantividade, ou seja, o que é incorporado à estrutura cognitiva é a substância do novo conhecimento, das novas idéias, não as palavras exatas usadas para expressá-lo. Os conhecimentos novos se encaixam em outros pré-existentes, não havendo razão para a imposição de "verdades" ou modos exclusivos de execução de tarefas. Em outras palavras, o que se aprende não é um passo a passo de termos sem sinônimos, propostas singulares ou processos únicos, senão o que chamo de "mensagem principal" de cada instrução. A partir dela que o aluno aprende a ignificar em seu conhecimento emergente os signos suficientemente adequados à realização de cada tarefa ou ato comunicacional.

Após experimentar formas mais envolventes e criativas de manusear o código linguístico, dificilmente o aluno almejaria voltar atrás e exigir aprender um idioma através da 
tentativa de acomodação de conteúdos em sua mente, que ele nem tem certeza de que usará algum dia, já que os objetivos comunicacionais também são díspares entre os indivíduos. É mais louvável confiar na capacidade criativa humana e buscar experimentar atividades ricas em desafios comunicacionais que nos impelem ao descobrimento de quais os itens lexicais e adequações sintáticas ainda necessitamos aprender para obter êxito comunicativo e como encaixá-los no contexto interacional. No relato do professor podemos ver que as formas de abordagem podem ser distintas ao ponto de gerarem uma tentativa de reconfiguração do significado da aprendizagem no indivíduo (provável motivo do bloqueio citado), apesar de não muitos educadores se atentarem a esses paradigmas.

Entretanto, alguns casos de sucesso observados nas escolas e a constatação de que muitos professores estão buscando diversificar suas estratégias, abrindo espaço para a experimentação de novas ferramentas e propostas, indicam que há um movimento forte nas escolas estudadas em direção à modernização do ensino e à criação de rotinas comunicativas que simulam uma imersão linguística. Como exemplo, analisamos outras três contribuições de professores que responderam a estas mesmas perguntas do Roteiro de Entrevista citado. A primeira, da professora Samara Cordeiro (CILC), demonstra como a partir de experiências pontuais é possível chegar a conclusões convincentes a ponto de transformá-las em projeto permanente na escola:

“O projeto final do curso de três anos para os alunos de ensino médio [também chamado de específico], que consistia em produzir cada grupo um trabalho de noticiário impresso, radiofônico ou televisivo, baseou-se no acesso a essas mídias via internet. $\mathrm{O}$ projeto durou um semestre inteiro. $\mathrm{E}$ foi apresentado nas modalidades oral e escrita contando com atividades de interação com os expectadores. Um segundo projeto foi voltado para o panorama da francofonia e turismo. Executado na modalidade semipresencial, cuja plataforma era um grupo no Facebook. Participaram alunos do curso de francês e egressos do CILC. Tivemos quatro encontros presenciais que serviram para orientar os estudos e trabalhos via internet que seriam culminados em sala nos encontros seguintes como fechamento de cada uma das quatro unidades do curso. Os alunos solicitaram a continuação do curso em outro módulo mais aprofundado em turismo. Eles superaram as expectativas linguísticas. O projeto melhorou o desempenho desses alunos em sala no curso regular de francês. O último não se trata de projeto, mas de atividades em que os alunos interagiram via whatsapp na língua estrangeira. No CILC o professor Euzébio desenvolve a produção de livro literário. Não tenho certeza se no slideshare ou algo semelhante [na verdade é a mesma ferramenta usada pelo informante anterior: Storybird.com]. São livros dos alunos com suas próprias ilustrações. Acho imprescindível a absorção das tecnologias de comunicação e atividades artísticas para promover maior contato dos alunos com a língua estrangeira. Nossos alunos vivem em um mundo onde tudo é mais interessante que os bancos da escola. Nós precisamos trazer o aluno para o nosso lado, buscando fazer da escola um ambiente atrativo. As novas tecnologias e as expressões artísticas são fortes aliados nesse intuito" (profa. Samara Cordeiro). 
O relato de que esses projetos despertaram o interesse de alunos egressos demonstra que há uma busca da comunidade escolar por novidades ou estratégias diferentes das que eles estavam acostumados, representando simbolicamente a existência de uma aspiração voluntária entre eles para continuarem aprendendo o idioma, porém de forma mais interacional e prática. Já são percebidos nessas escolas anseios por parte de alguns alunos em terem aulas com um professor específico ou participar de um projeto extraclasse que possa auxiliá-los a praticar o que vêm aprendendo, como é o caso do professor citado que tem seu projeto muito bem visto por alunos e professores. Isso demonstra como as estratégias de sucesso podem seduzir mais professores a experimentá-las, pois os professores também anseiam por práticas mais efetivas.

Muitos professores intuem que seus esforços e práticas didáticas são completos e enérgicos, mas que ainda assim precisam de formas de garantir que os alunos estejam absorvendo e produzindo insumo compreensível com maior frequência, tendo em vista que apenas as aulas presenciais não são suficientes para a ampla prática comunicativa. É preciso, conforme identifica esse informante, que as escolas tenham mais "iscas didáticas" para atrair os alunos a usarem de seus materiais, estruturas e ambientes para praticar a língua aprendida através de expressões artísticas diversas. Elas criam pretextos comunicativos que são muito ensejados para garantir-se uma prática comunicativa autêntica e por isso não devem ser esquecidas pelas escolas de idiomas. Produções de vídeos, contos, versos, músicas, notícias, quadrinhos, etc., podem suprir essas ambições por práxis mais dinâmicas de ensino/aprendizagem.

A segunda contribuição, do professor Yuri, mostra como que, a partir de algumas experiências de pesquisa de material audiovisual e de sua reprodução por meio de dinâmicas teatrais, ele se viu impossibilitado de abandonar tais recursos em suas aulas, devido às grandes vantagens percebidas:

\footnotetext{
"A atividade artística que eu realizei que considero de maior relevância é a atividade na qual os alunos, têm que se juntar em pequenos grupos. Eles escolhem filmes, séries ou qualquer outra mídia ligada a filmes e assim eles trabalham fazendo a notação do roteiro dessa cena, o glossário das palavras complicadas nessa cena (que tem em torno de um minuto) e eles fazem uma versão cênica. Eles apresentam então o glossário (as palavras mais complicadas dessa cena), essa peça de teatro (essa versão cênica da cena do filme) e logo depois eles apresentam a cena [original] do filme para que os alunos possam contrastar a peça com o filme. $O$ projeto se trata de tema aberto, onde eles podem escolher qualquer filme, qualquer série, qualquer musical. Enfim, desde que isso tenha a ver com a língua inglesa e seja um material original (ela não tenha adaptação na língua brasileira). Ele foi executado no CILC e quem participou foram alunos da própria rede de ensino do CILC no noturno. $\mathrm{O}$
} 
trabalho foi realizado em três etapas: separação de um filme em cena; segunda etapa: a preparação de glossário e apresentação cênica dessa cena; e etapa três que é somente a apresentação da cena com áudio em inglês e legendas em inglês. As repercussões foram incríveis porque os alunos chegavam a lembrar da cena nos próximos semestres, até um ano, um ano e meio depois os alunos ainda lembravam das falas e do filme, da cena em si, das palavras que estavam contidas naquela cena. Isso ajuda eles a aprender palavras novas de maneira adaptada para a língua deles, de maneira nativa. Elas trazem uma congruência... uma convergência pra essa vontade dos alunos em estudar uma língua estrangeira e sentirem mais motivados a tal. Então eu acho que ela é muito relevante e imprescindível. Na minha prática em sala de aula não existe mais a possibilidade de não trabalhar com tecnologia ou com atividades que tenham a ver com essa de interação com a internet, mídias sociais e outros. Eu avalio isso de forma absurda, porque os alunos trabalham com escrita, trabalham com áudio, trabalham com fala, com a leitura. Então todas as habilidades são feitas de maneira física também porque eles têm que interagir e executar uma cena. Então é bem... é um trabalho bastante... as engrenagens diferentes se encaixam fazendo um bom trabalho" (prof. Yuri).

Observa-se que pelo fato de este projeto ter sido baseado em cenas já existentes que não houve uma produção textual original. Porém, os alunos puderam praticar múltiplas habilidades e exercitar a criatividade pela adaptação intersemiótica. Sua observação de que tais experiências marcam positivamente a vida dos alunos, pois muitos demonstraram fortes lembranças desse engajamento, demonstra como a abordagem mais ativa de exploração textual, própria das atividades de produção criativa ou reprodutiva, pode ser muito mais relevante à aquisição linguística que o estudo linguístico passivo, representado pelas análises linguísticas isoladas do uso prático. Como a aquisição linguística está mais ligada a processos de desenvolvimento de conhecimento processual que declarativo, aproveitando essa clássica distinção feita por Anderson (1989), é possível deduzir que qualquer professor ou aluno que experimente as funções linguísticas dessa forma laboriosa perceberá que atualmente não há razões para conservar-se às abordagens meramente conceituais do idioma.

Vale observar que, ao ser esse professor citado por alguns expoentes de produções semelhantes nesta escola, esses projetos têm chamado a atenção da comunidade escolar e criado rotinas de intercâmbio de estratégias entre os professores. Como uns se apropriam das ideias dos outros já cientes dos êxitos, dificuldades, problemas e demais detalhes relacionados à experiência alheia, isso cria uma espécie de laboratório natural de pesquisa, experimentação e avaliação dos resultados capaz de lapidar os processos e procedimentos de ensino/aprendizagem. Este ciclo virtuoso promove uma profunda reflexão no ambiente escolar e enobrece os cursos de línguas, pois a ele também será atribuído o desenvolvimento de outras habilidades, linguísticas e extralinguísticas, valorizadas no ensino. 
Também ligada ao ELE através do uso da expressão teatral como recurso para a criação de práticas comunicativas autênticas, a professora Marisa nos lembra que o momento atual é muito mais favorável para o exercício do ensino produtivo apoiado às ferramentas digitais, já que nunca o acesso às informações e tecnologias de gravação e reprodução audiovisual foi tão fácil e disseminado:

\begin{abstract}
"É interessante que alguns projetos que nós desenvolvemos só foram possíveis mesmo por causa das modernas tecnologias. Na época [2006] a gente queria fazer um projeto. Era coordenado por mim, pela Cláudia e pela Alessandra, que ainda nem era efetiva na escola. Era um projeto de trabalhar as danças francofônicas, mas teve que ser adiado e só foi possível ser feito em 2008 com o advento do youtube, porque a gente pôde pesquisar a partir dos vídeos as danças de vários países francófonos. Então nós fizemos também um projeto de pesquisa e um trabalho de empreendimento porque a gente também apresentou em um evento de dança reunindo as danças mais importantes de 10 países, se eu não me engano. Em 2013 nós tivemos um projeto de música que foi muito interessante. Era um projeto que a gente queria abordar... era um projeto de pesquisa no qual o foco era você fazer uma pesquisa pra saber como é que eram as músicas francofônicas e como é que elas se relacionavam com as identidades francófonas. E então nós desenvolvemos um projeto, fomos pesquisar as músicas dos países que falavam francês e na época nós só conseguimos fazer um trabalho por que era um momento dentro da rede, da internet, em que você poderia baixar músicas. Então os alunos puderam fazer várias pesquisas baixando músicas de vários países e conhecendo os cantores, os compositores. E foi muito interessante. Foi um projeto de mais ou menos um ano. Foi um dos projetos mais proveitosos. Usavam aqueles programas que baixavam músicas. Então eles passaram a conhecer as músicas de diversos países e puderam finalmente chegar às perguntas de pesquisa que eles tinham. Então eu cito esses dois projetos por que eles não poderiam ser feitos na década de 90 , por exemplo. O nome do projeto era "As Danças Francófonas". Em ambos os projetos as modernas tecnologias de internet foram importantes. Diria até que sem as modernas tecnologias de internet seria impossível executá-las" (profa. Marisa Santos).
\end{abstract}

De fato, essas propostas de inserção nos cursos de línguas dos mais diversos modos artístico-comunicativos existentes, tão comuns atualmente, estão ligadas à massiva popularização de alguns dispositivos e tecnologias, tendo a internet e os smartphones como seus maiores representantes. O momento atual é marcado por mudanças nos modos de interação e comunicação. Consequentemente, é natural que todas as áreas de conhecimento que abordem a comunicação também acompanhem essas transformações e tentem responder às diferentes demandas e dinâmicas que estão emergindo como forma de manterem-se atuais e importantes para a sociedade. E é característico também desse momento a criação de dependência entre homens e dispositivos a nível tal que sem estes eles não consigam exercitar suas funções comunicativas com a completude exigida pela sociedade.

Entretanto, essa professora também menciona que, em contraste a esse panorama, há atividades tradicionais que continuam sendo vistas como relevantes ao ensino, devido a sua 
capacidade de proporcionar a seus atuantes experiência didático-interacional autêntica, como é o caso do teatro:

\begin{abstract}
"Já o teatro depende menos das tecnologias. Nós começamos a montagem de uma peça francesa, uma peça original que chamava "Les Caprices de Marianne", que não tem tradução em português, mas seria "Os Caprichos de Mariane". E nessa peça em si nós não dependemos tanto das novas tecnologias, pois já tínhamos o texto, mas até mesmo o acesso ao texto já estava mais fácil. Nós trabalhamos todo o texto, como no teatro. Ensaiando pouco a pouco, fazendo exercícios teatrais, até que se chega no final da memorização e quando a gente percebe que os alunos já estão prontos pra encenação. Apresentamos no Teatro da Praça [Taguatinga/DF], única apresentação. Fizemos depois outra peça que foi uma comédia. Essa peça nós aproveitamos o texto que estava na internet de um autor que só permitia que o texto fosse trabalhado em nível de amadorismo. Então foi muito interessante porque a gente entrou em contato com o autor. Ele divulgou a peça no sentido de divulgar na rede e na França que essa peça já tinha sido montada no Brasil" (profa. Marisa Santos).
\end{abstract}

Neste exemplo, percebemos também como o desenvolvimento das telecomunicações pode dar mais dinâmica aos projetos, permitindo maior interação entre pessoas e grupos. Isso abre ainda mais as possibilidades de aprendizagem colaborativa e pesquisa de material auxiliar para a execução dos projetos. Vivemos em um momento de maior distribuição e acessibilidade ao conhecimento e temos que aproveitá-lo para nos apossarmos de habilidades que possam facilitar nossa vida e tornar mais efetivas nossas propostas didáticas. Em projetos de produção audiovisual não é diferente. Cada participante atua com mais autonomia e contribui de forma mais ativa, seja por meio de pesquisas, ideias ou investimentos diversos. $\mathrm{E}$ não raras vezes observamos que suas rotinas interacionais são capazes de estimular maior desenvoltura e altruísmo nos sujeitos envolvidos, conforme evidenciado por esse informante:

\footnotetext{
"Tem um exemplo recente em que estamos trabalhando de novo com a peça e temos alguns alunos iniciantes. A gente percebe que o desenvolvimento deles é muito mais... a desenvoltura deles é maior. Nós fizemos um passeio num sábado. Uma visita guiada do Itamaraty. Foi em francês e as duas alunas que participavam do teatro foram as que tiveram mais propriedade pra perguntar. Então, geralmente o aluno que participa do teatro ele tem algumas facilidades. $\mathrm{O}$ teatro é um dos projetos mais completos que tem. Ele envolve várias habilidades, vários savoir-faire. $\mathrm{O}$ aluno tem que se expressar oralmente, tem que melhorar a voz, postura de voz, tem a questão artística, a questão de domínio da língua, ele tem que entender o texto, ele tem que falar o texto. Então é um projeto completo. O projeto de teatro é um dos mais desafiadores em termos linguísticos, mas existem outros projetos que fizemos que foram igualmente interessantes" (profa. Marisa Santos).
}

Essas observações são frequentemente feitas pelos informantes desta pesquisa e já é possível perceber mudanças no modo como alguns professores veem o ensino de língua estrangeira. Ele já não é mais visto como um conjunto linear de conteúdos graduais, onde cada tema gramatical tem seu pré-requisito. Já não é mais visto como um aglomerado de 
instruções pontuais supostamente suficientes para que os alunos as utilizem na conversação em geral. É, sim, visto preponderantemente como habilidade situacional que demanda a criação de experiências comunicacionais simuladas ou realistas, porém de autêntico uso linguístico, para serem desenvolvidas.

As observações assistemáticas dessa pesquisa concluíram que tais mudanças de mentalidade didática são perceptíveis de forma quase generalizada nas práticas docentes e esse informante nos mostra um pouco do ponto principal que os professores vêm questionando:

\footnotetext{
"Eu quero dizer que não existe o conteúdo de língua estrangeira, porque a gramática ela não é o conteúdo de língua estrangeira. Aliás, ela tem sido, de fato, mas não é realmente. O conteúdo de língua estrangeira é a comunicação, é a TV, é o teatro, é o rádio, é a música. Você pode começar um curso de língua estrangeira com qualquer coisa. Você pode fazer um curso de língua estrangeira somente pelo teatro. Vamos aprender língua pelo teatro, mas o que tem se colocado é que o conteúdo é a gramática" (profa. Marisa Santos).
}

Dessa forma, a solução para o aperfeiçoamento dos cursos de línguas não tem sido vista como um abandono das prescrições gramaticais, senão como um entendimento de que as funções linguísticas são adquiridas na interação comunicativa e de que a partir dela os aprendizes podem inferi-las, desde as regras mais fixas às mais nômades, recorrendo aos registros de uso padrão, representados pelos livros de gramática, para aperfeiçoar sua produção comunicativa e, assim, poder compreender melhor os falantes de um determinada comunidade e também ser melhor compreendido. Isso também corresponde aos interesses discentes, que estão mais ligados à aquisição e ao uso livre do código linguístico para promover comunicação, anteriormente ao desenvolvimento da precisão linguística.

A professora Adriana, a quinta informante entrevistada, também apresenta uma visão semelhante que denota como os professores estão buscando focar mais na comunicação do que na análise das estruturas linguísticas:

\footnotetext{
"A linguagem deles é desenvolvida não como objetivo da língua em si, mas com o objetivo da atividade, porque eles têm que entender que a língua que eles estudam aqui não é o fim, mas é o meio que eles vão utilizar pra fazer várias coisas na vida deles. Então eles encontraram isso. Eles que tiveram que buscar vocabulário, estruturas pra que eles pudessem melhorar as atividades, fazer um bom trabalho" (profa. Adriana Pires).
}

Essa compreensão a levou a promover atividades que permitem uma experimentação mais criativa do código linguístico, conforme ela descreve a seguir, após relatar uma experiência em que teve que ausentar-se da sala de aula por motivos de saúde e utilizou-se da 
interação virtual para que os alunos não ficassem sem aulas, pois naquele momento não seria possível encontrar um professor substituto.

\begin{abstract}
"Além disso, no semestre seguinte a gente fez muita atividade de vídeo e produção escrita. A produção escrita era basicamente de contos. Eu dava o inicio de uma historia, então eram narrativas. E é interessante como que a narrativa da chance para o aluno ser criativo. Então, eu dava o inicio de uma estória qualquer e eles tinham que continuar as estórias. Então, tivemos estórias maravilhosas, a quantidade de erros gramaticais, de vocabulário, foram muito pequenas, porque eles realmente se empenharam, porque gostaram da atividade. E eles tiveram a oportunidade de ler os contos em sala de aula, mostrar a produção deles em sala de aula. De forma geral foi muito bom, foi muito positivo. Eu nunca tinha trabalhado com parte escrita que tivesse uma repercussão tão positiva como foi esse, porque até então eles escreviam os essays, as dissertações, mas não muito narrativa, onde você pode usar mais a criatividade" (profa. Adriana Pires).
\end{abstract}

Nota-se que esta professora esperava com seu feedback suprir as deficiências gramaticais dos alunos, mas elas foram superadas principalmente por eles mesmos, provavelmente pelas livres consultas e observações linguísticas. Tal característica é algo comum no relato dos professores, pois atividades assim facilitam o surgimento de atitudes mais autônomas por parte dos aprendizes, que se veem como protagonistas no processo de aprendizagem. E tais atitudes mais responsáveis também viabilizaram a execução de outros projetos, como um de seus projetos de elaboração de vídeos temáticos que é amplamente reconhecido no ambiente escolar:

\begin{abstract}
“Os vídeos também eu sempre gostei de usar de uma forma interessante, porque eu pessoalmente não tenho muita habilidade para isso, mas acredito que os alunos têm. Então quais tecnologias eles podem utilizar? Eles usam o próprio celular. Muitas vezes, mesmo não tendo uma qualidade de vídeo, de áudio, muito bom, eles dão um jeito e sempre fica bom, porque se você exige também equipamentos muito sofisticados eles não têm acesso a essa tecnologia e isso pode atrapalhar a entrega do material. Então eles fizeram vídeos de acordo com os temas. Usaram a criatividade deles, entrevistaram professores, filmaram as dependências da escola, fizeram críticas sobre a estrutura da escola, a não atenção que o governo dá às escolas, aos centros de línguas. Então eles tiveram essa liberdade pra escolher o tema deles. Então foi muito interessante. No final do semestre a gente faz um grupo de alunos, eles apresentam os vídeos deles, eles fazem uma introdução em língua inglesa e apresentam os trabalhos deles. Então a avaliação foi muito positiva. Eles conseguiram utilizar a língua de forma correta, pois houve todo um processo tiveram que seguir: preparação, filmagens, correção, o professor têm que intervir muitas vezes pra ajudar. Mas quanto à criatividade, a produção de forma geral era deles" (profa. Adriana Pires).
\end{abstract}

Eis uma evidência de que não é imperioso um elevado conhecimento sobre processos e ferramentas de produção audiovisual para aventurar-se nesse campo. Há muitos outros exemplos de produções amadoras, algumas usando até aparelhos atualmente considerados 
rudimentares, que se destacaram na rede devido a seu alto grau criativo. Nos registros desta pesquisa se encontram alguns e em sites armazenamento de vídeos (youtube, dropbox, google drive, ondedrive, mediafire, etc.) é possível perceber como alguns jovens já dominam algumas dessas ferramentas em nível avançado. Alguns chegam até a fazer vídeos tutoriais para aumentarem suas redes de influência. Assim, apoiado pelos diversos tutoriais disponíveis na rede e, principalmente, pelo engajamento de seus alunos, os professores têm sido capazes de produzir materiais de alta qualidade e relevância educacional, criando espaços e atividades propícias para o trabalho dos principais temas transversais de interesse da escola.

Essa informante cita ainda que essa é uma tendência do ensino: aproveitar melhor as tecnologias já amplamente popularizadas, como os smartphones que oferecem inúmeros recursos, mas nem sempre os professores estão atentos a isso:

\footnotetext{
"Eu acho imprescindível o uso de atividades artísticas e tecnologias de comunicação, porque é o dia a dia hoje do aluno. Então eles têm acesso ao celular, eles gostam de usar o celular. Existe realmente uma corrente que traz essa ideia de "bring your own device". Que é "traga seu próprio aparelho e utilize ele a seu favor". Então o celular com o tempo passou de ser o vilão de sala de aula, pois os alunos ficam o tempo todo no celular e o professor tem que usar a criatividade e entender que ele pode ser usado à favor da aula dele. Então, os computadores, a maioria dos alunos conhece essa tecnologia, eles conseguem usar bem, a internet, eles usam bem e eles pesquisam sites. O Google é claro o mais utilizado. Então a partir dele você consegue achar outras ferramentas. Têm aplicativos gratuitos pra fazer vídeos, trabalhos com áudio. Então hoje é muito mais fácil do que na época quando eu era aluna" (profa. Adriana Pires)..
}

É crucial para a educação iniciativas que provem o poder que os indivíduos têm em mãos para protagonizarem seu próprio aprendizado e responderem aos dilemas e temas da vida moderna de forma fundamentada e criativa. Através delas tornam-se mais eficientes os esforços para absorção e distribuição de conhecimentos, para o desenvolvimento de imersões socioculturais, para o aumento do engajamento dos alunos e da participação, para a inserção sociocultural dos indivíduos, para proporcionar maior interação entre a classe, etc. Outros professores, sob nomes fictícios, também compartilham dessa visão:

“As ferramentas digitais são de extrema importância, pois dão a possibilidade de editar o vídeo, colocar legendas, inserir trilha sonora, etc.” (prof. Alan).

“Tais projetos são extremamente importantes para a formação de um falante de língua inglesa como segunda língua. As ferramentas digitais são uma forma muito eficiente de imersão sociocultural. O aluno aprende melhor se aprende e apreende cultura, ao invés de aprender somente a língua" (profa. Beatriz).

“As ferramentas digitais são importantes instrumentos para provocar uma maior participação e engajamento dos alunos em projetos de produção audiovisual. Talvez a maior dificuldade na utilização de ferramentas digitais seja do próprio professor. 
Nestes tempos é fundamental a utilização de ferramentas digitais, daí a necessidade de se investir na formação e aperfeiçoamento do professor" (prof. Carlos).

"Tudo aquilo que possa envolver o aluno fazendo com que aprenda mais é interessante, embora haja uma resistência dos professores por não dominarem a área de T.I (Tecnologias da Informação)" (profa. Daniele).

"O uso de ferramentas digitais auxilia de maneira significativa no processo de aprendizagem na língua estrangeira” (prof. Elias).

"Essas ferramentas, que uso frequentemente, possibilitam inserir o aluno no mundo do qual faz parte a língua que estudam, porque são capazes de transportar os alunos para outros contextos, sem sair de sala de aula. É muito importante ver a língua no dia-a-dia do mundo real. Essas ferramentas são capazes de proporcionar isso" (prof. Fernando).

"Esse uso de ferramentas digitais é importante para a promoção do treino (repetição), atividade imprescindível para a aprendizagem de língua estrangeira" (profa. Gisele).

"É algo muito positivo. Os professores devem explorar esses recursos digitais e tecnológicos, a fim de promover o envolvimento do aluno, bem como a interação da classe" (prof. Henrique).

E também compartilham algumas impressões sobre o desempenho dos alunos participantes dos projetos observados:

"Os alunos que participam de projetos de produção audiovisual, como o festival de curtas do CILT, por exemplo, apresentam uma evolução em sua fluência na língua inglesa devido à pesquisa de vocabulário para a construção de diálogos, além de assistirem a filmes legendados que servem de fonte de inspiração para a elaboração de seus curtas-metragens, bem como na tradução com as legendas. Os alunos também praticam bastante e pesquisam sobre a pronúncia e a entonação das frases" (prof. Ícaro).

"A evolução dos alunos que participam de tais projetos é claramente percebida durante o processo avaliativo. Vocabulário e fluência são melhorados. Participando destes projetos, alunos se tornam mais seguros para produzir o que lhes é ensinado ao longo do curso. Eles não mais "reproduzem" (profa. Janaina).

"Quando o projeto de produção audiovisual é bem orientado pelo professor os alunos se engajam e o resultado é bastante positivo. Percebe-se a evolução da fluência linguística" (profa. Karla).

"De fato existe uma certa evolução, principalmente no que diz respeito à aquisição de vocabulário específico utilizado em cada produção. Contudo, nem todos os alunos têm interesse na atividade, dado à carga de trabalhos acadêmicos ou ao simples desinteresse no projeto (preguiça, dificuldade de trabalhar em grupo, resistência a atividades extraclasse). Os alunos que participam ativamente do processo e se envolvem nas fases da atividade de produção têm um ganho linguístico maior do que os demais. Para os alunos que apenas realizam a tarefa para "nota" (avaliação) não existe ganho perceptível" (prof. Leandro).

"Os projetos nos quais procurávamos envolver nossos alunos na época eram voltados para artes cênicas, quando os mesmos treinavam a audição e a fala. A 
percepção da língua era assimilada com maior facilidade, ajudando dessa forma em sua fluência linguística" (profa. Marcia).

“Os alunos que se dedicam a projetos de produção audiovisual demonstram uma maior evolução linguística, pois os alunos desenvolvem um conhecimento amplo do projeto desenvolvido" (profa. Nayara).

“Acredito que, por falta de cumprir com as tarefas de casa e estudar a língua apenas no momento da aula, os alunos têm dificuldade de melhorar mais o domínio da língua. Entretanto, os projetos são sempre motivos para o envolvimento mais intenso com o curso e para o contato com aspectos culturais que estimulam o interesse" (prof. Oscar).

"Percebi a evolução da fluência dos alunos a partir do momento em que vi que eles se mostraram mais seguros na hora de expressar suas ideias e opiniões à turma" (prof. Paulo).

"Os alunos que têm contato com projetos de produção audiovisual têm uma tendência melhor evolução na oralidade, pois estão dentro de um trabalho prático. Eles também se sentem mais à vontade para falar no idioma estudado. Sem contar outros fatores dinâmicos que projetos audiovisuais proporcionam aos alunos, contribuindo para essa evolução da oralidade" (profa. Quésia).

Esses resultados positivos observados se dão provavelmente devido à maior atenção dada ao terceiro estágio do que consideramos serem os três mais importantes de memorização linguística ${ }^{11}$ da segunda língua na aprendizagem instruída:

- Primeiro estágio: memorização do verbete, nele ainda não estão amadurecidas as possibilidades semânticas que as palavras podem assumir segundo as mudanças contextuais. É feita uma equivalência com alguma palavra da língua materna, porém essa equivalência nunca é perfeita, pois os vocábulos são díspares em usos e representações conotativas.

- Segundo estágio: nele já está presente a maioria das possibilidades semânticas que uma palavra pode assumir, porém ainda não foram experimentadas de forma suficiente para gerar maior segurança na expressão do falante. Trata-se de uma equivalência potencial que se conforma na memória do aprendiz, mas que ainda precisa ser provada pela prática comunicativa para ser usada com maior fluidez e propriedade.

11 Tal memorização linguística é vista aqui como uma construção de conhecimento além das habilidades mnemônicas primárias. 
- Terceiro estágio: nele as equivalências do segundo estágio já obtiveram respostas suficientes, feedbacks, que fazem com que o falante tenha certeza de que tal verbete se encaixa propriamente no contexto em uso. É quando a fluência pode ser exercida com maior segurança, pois o falante sente-se capaz de corresponder às demandas comunicativas que podem emergir em uma situação interacional.

Considero que este último modo de memorização só é possível pela experiência prática, pelo uso autêntico da língua. Se usarmos o mesmo raciocínio para explicar a memorização dos demais itens mórficos e sintáticos dos idiomas é possível perceber que também as adequações gramaticais dependem menos de estudos analíticos e mais de experiências de uso para serem fixadas. Saber o que dizer e como dizer em um contexto interacional dinâmico, como é o uso real da língua, é um dos principais desafios linguísticos que os falantes enfrentam e só pode ser desenvolvido pela livre experiência volitiva e de forma idiossincraticamente única, já que nenhum falante demonstra idêntica competência em relação aos demais pertencentes da comunidade.

\subsection{SOBRE FERRAMENTAS DIGITAIS PARA PRODUÇÃO AUDIOVISUAL}

Visto por muitos estudiosos como um direito fundamental (FROSINI, 2013), o acesso à internet tornou-se tão importante para o ensino em geral quanto a sala de aula e seus materiais, dado que os modos de estudar modernos recorrem mais a essa ferramenta do que às bibliotecas ou salas de estudo. Já é possível considerá-lo com crucial para o êxito de um indivíduo nesse mundo globalizado, pois sem ele nem mesmo o exercício da cidadania está garantido, já que muitos conhecimentos, informações e serviços públicos estão acessíveis principalmente através dessa rede. Isso o coloca em pé de igualdade com muitos direitos fundamentais, conforme percebia Frosini (2013): "O direito de acesso à internet tem que ser considerado um direito social ou, mais ainda, como um dever do Estado, assim como serviços de educação, saúde e bem-estar" (FROSINI, 2013, p. 230).

Nesse novo panorama a internet também vem se repaginando, possibilitando novos e cada vez mais avançados recursos pra atender necessidades de todas as naturezas, desde os propósitos mais subjetivos, relacionados a um modo tácito de relacionar-se com as informações e possibilidades interacionais que ela provê, aos mais objetivos, representados pelos usos guiados onde uma ferramenta disponível nessa rede é empregada para a realização 
de um fim específico. Ante sua abundancia instrumental, o olhar do professor tende a buscar em cada site ou aplicativo um préstimo didático que possa viabilizar seu uso no ensino, aproveitando parcialmente ou integralmente suas funcionalidades para propor atividades mais dinâmicas e interativas como forma de inserir a si e a seus alunos em um mundo cada vez mais marcado pelo enlace entre o virtual e o tangível.

Atualmente é crescente o interesse por parte dos professores de LE em absorverem as funcionalidades tecnológicas modernas para atualizar seus cursos e corresponder às expectativas do ensino atual, onde os alunos estão cada vez mais familiarizados com o universo da internet e demais ferramentas de informática. Ao se informar sobre cada novo aplicativo ou site com popularidade crescente entre os alunos os professores se veem diante de um dilema: absorver prontamente os novos utilitários que conquistam a atenção discente ou resistir às mudanças emergentes no modo de relacionar-se com a informação que eles propõem. Entretanto, a pergunta que mais desafia as práticas docentes vigentes é como absorver tal tecnologia de forma a aproveitar melhor seu potencial didático, já que muitas das ferramentas disponíveis também podem promover distrações aos objetivos do curso quando usadas de forma pouco estratégica ou ingênua.

Para um melhor entendimento de quão proveitosas essas ferramentas podem ser para o ensino de línguas faz-se necessário o entendimento de que elas servem apenas para auxiliar a execução de atividades didáticas que visam estimular a aquisição linguística através da produção de textos multimodais: realizados por diferentes códigos semióticos (KRESS \& VAN LEEUWEN, 1996), ora pela simplificação que elas promovem nos processos de produção audiovisual, ora pela economia que elas possibilitam entre seus usuários, auxiliando-os na execução de seus projetos. Dessa forma, conhecer quais são as atividades de produção linguística que podem fomentar um maior uso da língua alvo entre os alunos e, consequentemente, maior competência comunicativa é imprescindível para que os professores de idiomas possam exercer seus papéis de forma mais ampla. E conhecer quais ferramentas podem ajudá-los a chegar nesse objetivo com maior precisão, economia, celeridade e qualidade é vital para superar um dos principais desafios didáticos do mundo moderno: a atualização dos cursos conforme às mudanças recentes nos modos de comunicação, aprendizagem e interação.

Para tanto, essa pesquisa propõe também uma reflexão sobre as atividades reconhecidamente relevantes à aquisição linguística - principalmente por auxiliarem a praticar a língua alvo de forma autêntica, criando simulações de uso real da língua entre os alunos - e indica algumas ferramentas digitais entre as mais conhecidas e usadas para cada 
objetivo didático. Isso conforma seu caráter utilitário ao ensino de LEM, pois tanto professores experientes como novatos carecem de ideias e propostas que possam inspirá-los a desenvolver projetos didáticos para superar os desafios de aprendizagem linguística no contexto brasileiro. Contudo, isso não o coloca em statuts de "receita didática infalível", já que a eficácia das atividades e ferramentas disponíveis também depende dos movimentos de aperfeiçoamento didático naturais à prática escolar.

Para nos esquivar de uma apresentação muito esquemática optamos por contemplar algumas considerações teóricas que exaltam o proveito de cada atividade seguindo apenas uma convenção dirigida pelas potencialidades de cada uma e pela oportunidade de discorrer sobre elas. Da mesma forma estão listadas as ferramentas úteis para o desenvolvimento de cada tarefa evidenciada por este trabalho, mas é importante observar que tanto as ferramentas quanto as vantagens advindas de cada proposta de produção audiovisual para fins didáticos podem apresentar funções e usos extensíveis às demais atividades, ou seja, ao discorrer sobre um tipo de produção proeminente, como a produção teatral, por exemplo, constrói-se considerações que podem coincidir com as observações advindas da prática de produção de animações, filmes, etc. Acreditamos que isso possa proporcionar uma dinâmica mais agradável ao texto, pois forma uma construção gradual e não reducionista, já que todas as produções compartilham epistemologias e préstimos entre si.

\subsection{ATIVIDADES DE PRODUÇÃO AUDIOVISUAL E SUAS FERRAMENTAS}

Em meio às inúmeras possibilidades de uso de FD para apoiar atividades de prática linguística e segundo motivos convencionais, apresentamos as reflexões sobre as potencialidades e utilidades das ferramentas consideradas por esta pesquisa como mais relevantes à aprendizagem/ensino de línguas e as divido em duas categorias principais:

- Atividades e Ferramentas de Apoio à Produção Oral: representadas pelas que apresentam como produto final textos audiovisuais (palestras, filmes, canções, documentários, teatro, dança, TV, rádio, etc.).

- Atividades e Ferramentas de Apoio à Produção Escrita: representadas pelas que apresentam como produto final um texto escrito (livros, jornais, revistas, charges, histórias em quadrinhos, artigos, ensaios, blogs, etc.), impressos ou não. 
Entretanto, essa classificação é conveniente somente para fins de organização das considerações sobre o perfil utilitário de cada atividade, pois ao trabalhar com a produção multimodal no ensino de línguas é imprescindível buscar um desenvolvimento holístico das habilidades, ou seja, desenvolver as habilidades de produção e compreensão, orais e escritas, de forma cooperativa, indissociadas no processo de ensino.

Como exemplo vale citar as atividades de produção oral que começam a partir de atividades de produção escrita, como é o caso da produção de documentários, a primeira atividade apresentada neste trabalho. Tais atividades tendem naturalmente estimular o uso linguístico em suas múltiplas habilidades e servem de parâmetro para a promoção dessas mesmas características nas demais atividades de produção para que elas possam servir aos aprendizes com maior completude funcional.

Uma vez que as possibilidades são diretamente proporcionais à criatividade dos produtores, apresento as ferramentas mais conhecidas no meio docente pesquisado e algumas potencialmente úteis e disponíveis aos usuários brasileiros, listando-as apenas com seus nomes quando puderem ser facilmente encontradas através das ferramentas de pesquisa mais comumente usadas atualmente:

\subsubsection{Produção de Documentários e Audiolivros}

Documentários, dentro de uma perspectiva simplificada às necessidades práticas de seu uso em sala de aula e evitando termos muito técnicos próprios da produção de documentários profissionais, são vídeos informativos ou instrucionais sobre qualquer coisa que valha a pena ser conhecida com maior profundidade. Seu caráter científico se dá pela exigência de fontes seguras e por uma pesquisa consistente sobre o tema a ser documentado. Podem também ser feitos para fins de entretenimento, o que relativiza seus modos de apresentação textual e visual. Sua produção envolve três principais tarefas:

1) Produção do Texto: nessa etapa o aluno, ou grupo de alunos, deve fazer uma redação baseada nas informações disponíveis sobre o objeto de estudo e seguindo as exigências metalinguísticas sugeridas pelo professor. Sua construção é livre quanto às tipologias e gêneros textuais utilizados, configurando-se como oportuna atividade para a composição ou apreciação de textos narrativos, dissertativos e descritivos, assim como poemas e contos em formas multissemióticas (recitação, música, trechos de filmes, etc.); 
2) Produção do Áudio: nesta etapa o aluno grava sua leitura do texto produzido na etapa anterior, produzindo um arquivo de áudio que será a base para a etapa posterior. Ela é oportuna para desenvolver e avaliar a fluência de leitura e pronúncia na língua em estudo e não consiste ainda no áudio final do documentário, pois poderão a ele ser somados áudios de vídeos e fundos musicais para a produção do vídeo final, feito na próxima etapa.

3) Produção do Vídeo: nessa etapa organizam-se as imagens, vídeos, fundos musicais e os relacionam sincronicamente ao áudio gravado na etapa anterior, utilizando editores de vídeos e as demais ferramentas propostas neste trabalho. O produto final desta etapa, o documentário, ainda serve de motivo para outras estratégias didáticas, como debates, revisões gramaticais e avaliação processual ${ }^{12}$. É oportuno destacar que o processo de ensino/aprendizagem de línguas possui características ímpares que faz como que a avaliação formativa figure-se como ideal para mensurar suas complexidades (BARROZO, 2016).

Essa produção possui notável utilidade para o ensino de línguas. Apesar de haver múltiplas possibilidades de construção de seu texto e modo de apresentação, os documentários tradicionais - em que o aluno precisa pesquisar sobre um tema, redigir sobre ele e apresentálo em forma de vídeo narrado - permitem algumas características bem-vindas à prática de aprendizagem/ensino:

- Por partirem de uma construção textual escrita, eles oportunizam o desenvolvimento das habilidades de redação por parte do aluno e, consequentemente, o tratamento das questões gramaticais, desde as mais elementares às mais avançadas. Estas atividades facilmente se transformam em oficinas de redação e estilo e fomentam a percepção das características textuais em suas transições intersemióticas. A partir de então

12 Sinônimo de avaliação formativa ou contínua, a avaliação processual refere-se à prática de examinar a aprendizagem ao longo das atividades realizadas em sala de aula: produções, comentários, apresentações, criações e trabalhos em grupos, etc. 
habilita seus participantes a compreenderem as distintas nuances, limites e possibilidades entre textos escritos e falados.

- Ao relacionar seu texto de origem às imagens e vídeos usando ferramentas de edição audiovisual, os estudantes têm a oportunidade de perceber o valor da imagem na comunicação e as sutilezas de construção de sentido possibilitadas pela manipulação pictórica, além de aprender a utilizar melhor essas ferramentas fortemente valorizadas atualmente. Esses momentos também são oportunos para promover reflexões sobre o poder da imagem para mover a opinião pública, políticas sociais, etc. (HARPER, 1994).

- A inserção de legendas nos vídeos costuma ser relevante à aprendizagem, pois permite a prática da tradução, habilidade importante para compreender quais os modos comunicativos que a língua materna e a língua alvo compartilham, assim como um exercício maior de observação textual, em casos de legendas na mesma língua do áudio. Essa prática também tem uma função comunicacional relevante quando ela permite que também os alheios ao curso de línguas, como alguns familiares e demais interessados, por exemplo, tenham uma noção sobre os conteúdos satélites ao ensino de línguas que foram desenvolvidos. Isso lhes dá uma noção maior sobre a riqueza desses cursos que abarcam não somente o tratamento restritivo do código linguístico, mas toda uma gama de conhecimentos e informações inerentes a ele.

- Estes conteúdos satélites, mais conhecidos como temas transdisciplinares, merecem destaque, pois fazer um documentário significa também expressar opiniões, baseadas em informações cientificamente construídas na pesquisa, sobre os mais variados temas universais, como desenvolvimento sustentável, reciclagem, efeito estufa, poluição, política, educação, saúde, esportes, entretenimento, etc. Por serem eles valorizados nos Parâmetros Curriculares Nacionais (PCNs, 2002), tais atividades são oportunamente efetivas para cumprir com os Projetos Político-Pedagógicos (PPPs), que cada escola constrói baseando-se nesses parâmetros e na Lei de Diretrizes e Bases da Educação Brasileira (LDB 9394/96).

Audiolivros, também conhecidos como livros falados, por sua vez também possuem valorosa serventia ao ensino em geral. Sua produção é semelhante à produção de documentários, porém cumprindo apenas as etapas 1 e 2 citadas e não costumam partir de uma construção textual original, tratando-se apenas de uma locução de um livro considerado 
importante pelos integrantes do curso. Seu produto pode exercer uma função social de grande destaque à medida que auxilia na inclusão de deficientes visuais, permitindo uma maior cooperatividade entre alunos com necessidades diversas, além de compartilhar de algumas vantagens citadas nas considerações anteriores sobre documentários. Ainda, auxiliam na integração do corpo discente pela promoção de leituras conjuntas, pois permitem que os grupos apreciem de forma mais dinâmica e uníssona as obras literárias de seu apreço.

Há também registros de pesquisas que comprovam como pode ser exitoso o uso de audiolivros em sala de aula, desde as atividades mais primárias - como a leitura em voz alta de obras literárias para crianças ou o uso de audiolivros disponíveis em mídias digitais para fomentar a leitura no ensino em geral - até sua criação pelos próprios alunos. Beers (1998), por exemplo, mostra que audiolivros funcionam como um andaime que permite que os alunos leiam em um nível superior a seu nível atual.

É visível a importância dos audiolivros para o ensino de línguas. Na maioria das escolas, inclusive nas escolas pesquisadas, há a venda de livros impressos que acompanham CDs com suas versões em áudio. Esses áudios não raras vezes são usados em aulas e testes, porém fabricá-los pode ser ainda mais proveitoso para favorecer a aquisição linguística entre os alunos.

Um ponto positivo da produção de audiolivros e atividades semelhantes para fins didáticos no contexto brasileiro que ressalto é que, ao serem feitos pelos estudantes, apresentam amostras de uma fluência em construção e com características do Brazilian English que, além de facilitar a compreensão oral dos demais aprendizes, oportunizam uma avaliação da entonação, da pronúncia e do ritmo do áudio, bem como uma comparação com variantes nativas do inglês. Isso pode criar um corpus interessante para pesquisas, dado que há escassos estudos sobre quais desvios típicos de pronúncia cometidos pelos estudantes brasileiros são aceitáveis ou com qual variante do inglês eles se assemelham.

\subsubsection{Ferramentas Relacionadas a esta Atividade}

Esses documentários são feitos a partir de ferramentas simples e podem evoluir ao nível profissional com a utilização de ferramentas e estratégias mais rebuscadas. Para a parte de produção textual os principais editores de texto disponíveis no mercado, como o Microsoft Word, o BrOffice e o online Google Docs, por exemplo, são suficientes e para a produção audiovisual os aplicativos de gravação de áudio e vídeo, já integrados aos smartphones, 
aliados a editores de vídeo disponíveis - desde os mais elementares, como o Movie Maker e o Video Spin, por exemplo, até os mais requintados, como o Sony Vegas, o Lightworks e o Adobe Premiere Pro - são capazes de produzir vídeos de impressionante qualidade.

Cabe ao professor e sua turma a escolha de qual atende melhor suas necessidades, porém é importante levar em consideração que a escolha de uma ferramenta que demande conhecimentos avançados de informática pode desestimular os menos letrados digitalmente ou fazer com que se despenda muito tempo em instruções sobre como usá-la. Há ainda opções online para edição de vídeos em geral, como os sites apresentados a seguir no Quadro 1, que são bastante completas, chegando algumas a permitir a inserção de traços de animação nos vídeos criados, desde que o usuário disponha de internet de suficiente qualidade.

Quadro 1 - Editores de Vídeo Online

\begin{tabular}{|c|c|}
\hline WEV'DeO & https://www.wevideo.com/hub?newbUser=true\#route \\
\hline$\underset{W I R E W A X}{\infty}$ & http://www.wirewax.com/home/create-own \\
\hline eflix & https://studio.stupeflix.com/en/create/ \\
\hline E & $\begin{array}{l}\text { (http://www.wondershare.net/ad/video-editor-win/ filmora- } \\
\text { dco.html?gclid=CM7L592FvMwCFQ4EkQod47sIJQ) }\end{array}$ \\
\hline nicloo & http://wideo.co/pt/ \\
\hline
\end{tabular}

\subsubsection{Produção de Filmes e Vídeos em Geral}

As atividades de produção cinematográfica para fins didáticos estão entre as mais desafiadoras e possuem características muito bem-vindas ao ensino, já que oportunizam o desenvolvimento do senso de coletividade e da criatividade. Além das habilidades de escritas e orais, elas envolvem também habilidades de planejamento, raciocínio lógico e coordenação (MOHANTY, 2011).

Consideramos dois modos principais de produção de filmes em sala: descendente ou ascendente. No modo descendente todo o planejamento criativo fica a cargo do professor e os alunos apenas encenam e filmam as falas. Esse modo é recomendável quando se percebem muitas limitações à criação original no grupo ou em adaptações intersemióticas de obras célebres, assim como em possíveis participações em projetos já em andamento. No modo ascendente, a maior parte do trabalho, desde o planejamento à execução, fica a cargo dos alunos e o professor atua apenas na coordenação do projeto. Este modo propicia ao grupo 
discente um maior desenvolvimento das habilidades citadas, sendo assim mais recomendado, porém, por apresentar menor celeridade e maior dispersão, deve ser estudado de forma mais cautelosa antes de ser executado.

Normalmente essas atividades se dividem em cinco tarefas principais que por si só já trabalham diversas áreas do conhecimento:

1) Roteiro escrito ou visual: nesta fase, em que a construção textual está em foco, o professor aproveita para ministrar sobre aspectos textuais importantes para a criação literária, desde os metalinguísticos aos estilísticos, e sobre as demais instruções referentes à criação do roteiro escrito (script) ou do roteiro visual (storyboard), que não necessariamente precisa ser feito por alguém com expertise em desenho, ao contrário do que muitos pensam. A seguir apresentamos uma amostra de cada tipo (Figura 4 e Figura 5) e uma amostra de como ficou esta cena no vídeo final (Figura 6), feitos a partir de um filme ${ }^{13}$ realizado por este pesquisador junto aos alunos do CILC: "El Asesino Del Profe" (Quadro 2).

Quadro 2 - Sinopse do Filme "El Asesino Del Profe"

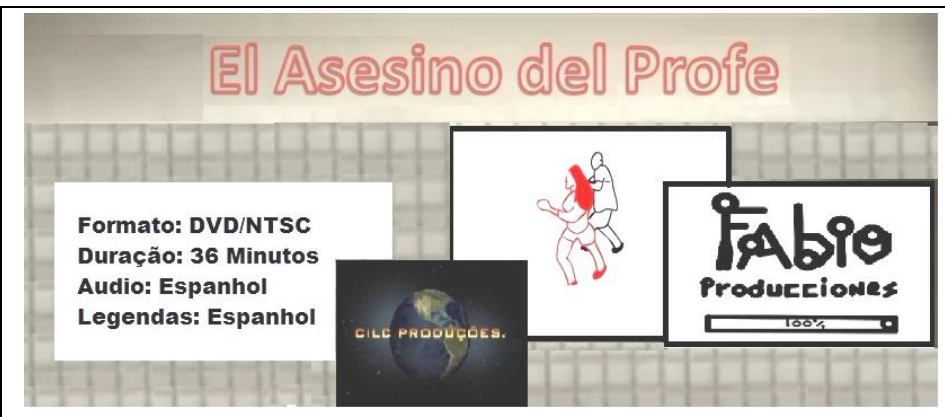

Sinopse: um grupo de investigadores interrogam diversos personagens em busca de solucionar um intrigante mistério: o assassinato do professor de espanhol. (Duração: 36 min; Idioma e legendas em espanhol).

Disponível para visualização nos endereços:

https://1drv.ms/v/s!AgvN1 kn1alqVhCWYDzt3iGZ7ZhOh 96

https://www.youtube.com/watch?v=Av-c7xS9SWU

http://www.4shared.com/web/embed/ file/4BygYfECba

(Amostra de projeto realizado em 2011)

\footnotetext{
${ }^{13}$ Tal é fime é o resultado de um projeto realizado no segundo semestre de 2011 junto com os alunos do CILC (turma E3, noturno) e oportunizou aos envolvidos experimentações linguísticas em atividades de elaboração e reprodução textual e audiovisual, bem como o desenvolvimento de habilidades cênico-comunicativas.
} 
Figura 4 - Roteiro Escrito

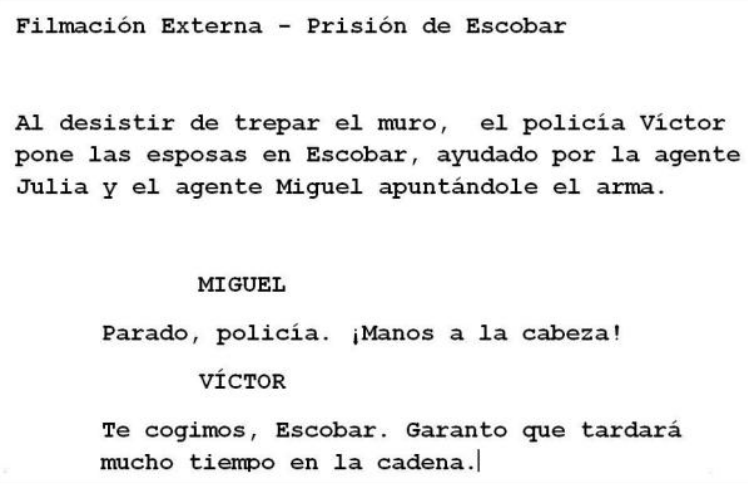

Te cogimos, Escobar. Garanto que tardará mucho tiempo en la cadena.|

(Amostra de projeto realizado em 2011)
Figura 5 - Roteiro Visual

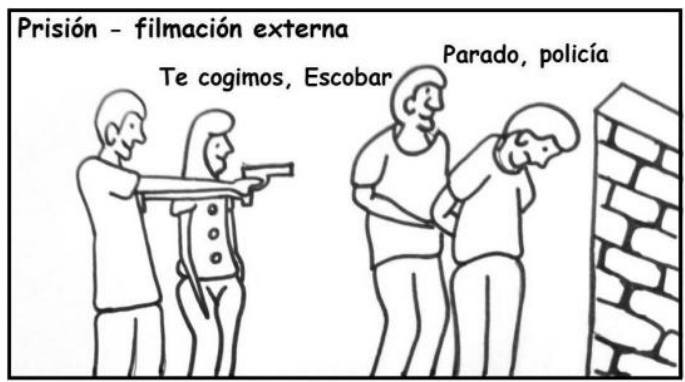

Nada más Escobar desistir trepar el muro, Víctor le pone las esposas, ayudado por Julia y Miguel (apuntándole el arma)

(Amostra de projeto realizado em 2011)

Figura 6 - Amostra de Cena do Filme "El Asesino Del Profe"

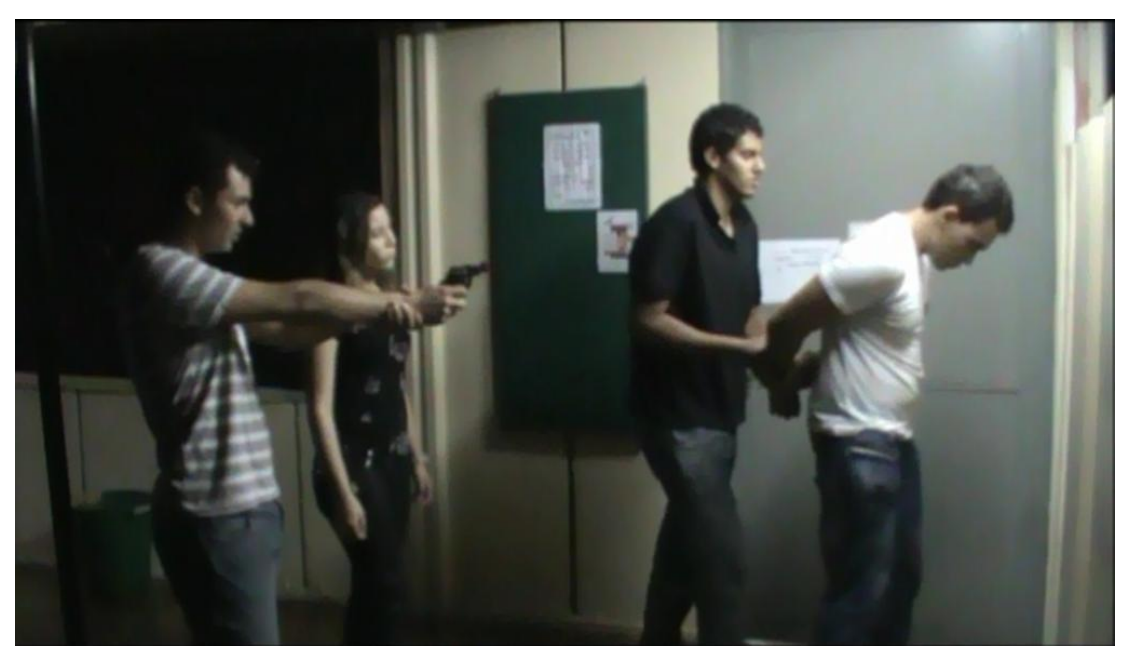

(Amostra de projeto realizado em 2011)

2) Cenografia e figurinos: a construção visual, desde os cenários às roupas que os atores irão usar também merece importante atenção. A primeira vista esta parte sugere muita pesquisa, trabalho e dispêndios financeiros, mas há muitos professores que preferem não descaracterizar o fato de o filme estar sendo feito dentro da escola, ou por seus alunos, e não investem muito nessa parte. E há casos em que a criatividade e a reciclagem de materiais deixam essa parte menos onerosa e mais alinhada aos objetivos educacionais, já que atividades de reciclagem criativa são de interesse da escola.

Há também recursos de fácil acesso e uso - como os de detecção de borda, que deixam o filme parecido com um desenho a lápis, úteis para diminuir a exposição dos alunos nos vídeos; e os de chroma key (também chamados de "fundo verde", color keying, CSO, green screen ou blue screen), que permitem grande manipulação dos cenários à medida que 
filmam-se as cenas diante de um fundo monocromático (normalmente azul ou verde) e na edição do vídeo insere-se o cenário de fundo desejado - que ampliam as possibilidades de construção cenográfica e, consequentemente, de construção de estórias.

De fato, os recursos de edição e de efeitos especiais estão se desonerando e se popularizando. É fácil encontrar jovens que já dominam muitas dessas possibilidades e publicam filmes de notável elaboração na internet, mas a escola ainda está há um passo atrás dessa geração informatizada.

3) Filmagem: a escolha da filmagem, seus ângulos e dispositivos eletrônicos, é bem livre, porém há de se observar a qualidade desejada e o tipo de arquivo produto dessa etapa para torná-la menos onerosa, pois cada editor tem preferência por um ou mais tipos de arquivo e uma má escolha pode fazer com que se gaste muito tempo com a conversão dos arquivos de vídeo. Recomenda-se usar mais de uma filmadora para enriquecer as possibilidades de edição, mas em alguns casos é preferível o uso de apenas uma câmera para simplificar o processo.

Esse momento é propício para praticar atividades de exploração do ambiente interno, a escola, e do ambiente externo a ela. Aprender a ver a escola e sua cidade com outros olhos, refletir sobre as inter-relações entre os modos de vida vigentes e sua retratação audiovisual e praticar atividades colaborativas podem sublimar o papel da escola e de suas tarefas, assim como seu valor pragmático na formação de cidadãos reflexivos e com elevada capacidade de apreciação artística. Também pode ser um momento propício para retratar fatos e situações que mereçam atenção, além das belezas e deslustres de uma comunidade. Isso auxilia na construção da identidade do aluno e na identificação com a escola e sua cidade, construindo uma perspectiva mais ativa sobre as características sociais contemporâneas.

4) Edição: a edição de vídeos é oportuna ao desenvolvimento de maior letramento digital nas ferramentas relacionadas. É também momento de escolha do que será aproveitado ou não, o que será mostrado ou não. É quando se começa a ter uma noção do que significa fazer um filme, das diferenças entre o mundo real e o mundo pictórico. É quando se criam e se inserem as legendas e aproveitam para praticar as vantajosas atividades de tradução descritas anteriormente. Enfim, é o momento em que a expertise no uso das ferramentas escolhidas e a criatividade se unem em direção a um produto final que possa chamar a atenção do telespectador: o filme. 
5) Apresentação: esse filme é muito útil para o ensino, pois figura-se como recurso didático para todas as escolas que, a partir dele, viabilizam inúmeras dinâmicas e atividades comunicativas, desde debates e seminários a avaliação das habilidades de compreensão oral. De fato, o filme produzido já serve por si só como dispositivo de avaliação e simboliza-se como um registro de algo relevante feito na escola e que o aluno poderá guardar para a vida inteira, ou seja, mais uma atividade marcante na vida do aluno que molda seu futuro e sua visão sobre o papel da escola e da educação na formação do cidadão e seu país.

Processualmente semelhantes à produção de filmes e compartilhando de suas ferramentas, as demais produções de vídeos - como comerciais, documentários, vídeos de previsão do tempo, apresentação de notícias, entrevistas, videoblogs (vídeos de opinião), vídeos instrucionais, etc. - merecem notável consideração no ambiente de ensino. Essas atividades são geralmente definidas pelo uso de diversas mídias (imagens, sons, texto, vídeo e narração) para transmitir um sentido (MOHANTY, 2011) e oferecem experiências e oportunidades de aprendizado tão abundantes que podem seguramente ser consideradas como apropriadas e poderosas ferramentas para o ensino de línguas no século XXI (THEODOSAKIS, 2001). Ainda, este autor ressalta que "a habilidade de criar sentido a partir da solução de um problema traz consigo uma profunda construção do conhecimento" (THEODOSAKIS, 2001, p. 41).

Tais atividades partem de estratégias razoavelmente equivalentes, porém seu produto final, o vídeo, pode ser tão diverso quanto a criatividade de seus produtores. Vale ressaltar também que essas atividades apresentam relevantes desafios aos participantes, que se veem impelidos a superá-los. Esse valor simbólico da superação de obstáculos é algo que o aluno pode levar para a vida inteira, uma vez que estabelece uma espécie de "cultura do triunfo", que pode ajudá-los a obterem êxitos futuros.

\subsubsection{Ferramentas Relacionadas a estas Atividades}

${ }^{14}$ Expressão que uso aqui para referir-me ao modo distinto de colocar-se diante das adversidades que muitos indivíduos desenvolvem, semelhante ao que a psicologia chama de resiliência, ou seja, um fenômeno comum relacionado ao desenvolvimento do ser humano (MASTEN, 2001). 
Para o desenvolvimento do roteiro escrito são usadas desde as ferramentas citadas na páginas 93 e 94 a algumas próprias para tanto disponíveis online. Da mesma forma, para o desenho do roteiro visual há copiosas ferramentas digitais específicas, mas não chegam a substituir a preferência que grande parte dos roteiristas têm pela tradicional e ainda não obsoleta dupla de ferramentas básicas da educação: lápis e papel. Entre as disponíveis online citamos a seguir alguns sites e aplicativos que consideramos mais relevantes e que servem para a criação de contos em geral ou qualquer atividade que envolva a escrita criativa.

Quadro 3 - Ferramentas para a produção de roteiros visuais (storyboards)

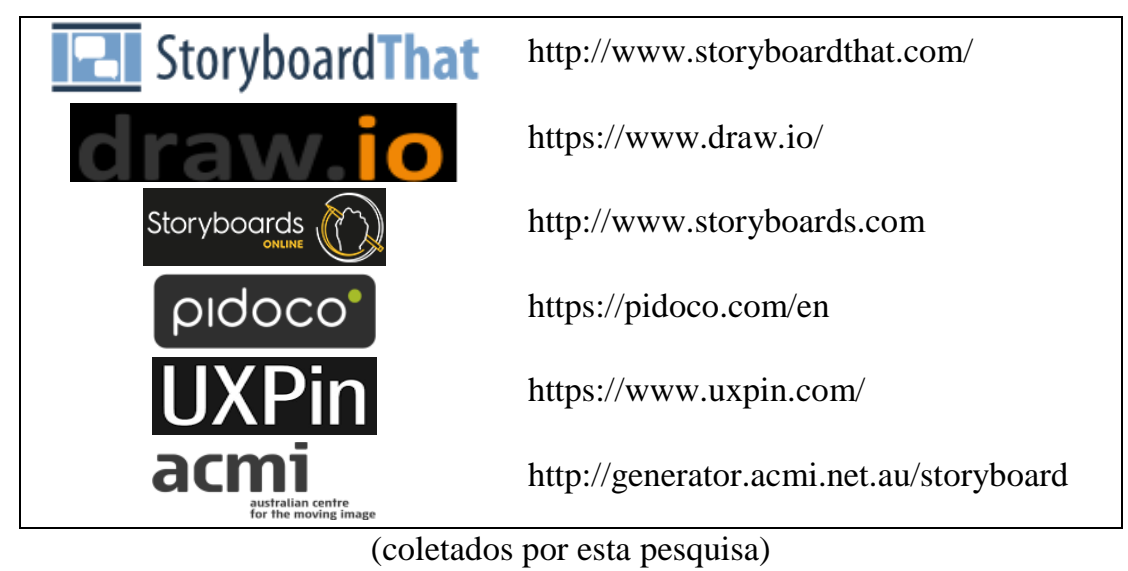

As ferramentas do Quadro 3 estão elencadas entre as mais conhecidas no âmbito da internet para a produção de storyboards, sendo que algumas são gratuitas e outras com planos gratuitos e pagos. Também há aplicativos de fácil localização na web a partir de seus nomes, como os listados a seguir no Quadro 4.

Quadro 4 - Aplicativos para a produção de roteiros visuais (storyboards)

\begin{tabular}{|cc|}
\hline \multicolumn{2}{|c|}{ Aplicativos } \\
storyboard maker & sketchbook express \\
storyboard pro & paper (by fiftythree) \\
toon boom storyboard & animation desk \\
atomic learning's storyboard pro \\
articulate storyline \\
penultimate & storyboards $3 d$ \\
storyboard composer & frameforge previz studio's emmy \\
storyboarder toolbox & storyboard studio \\
storyboarder & index card \\
& procreate \\
(coletados por esta pesquisa)
\end{tabular}

(coletados por esta pesquisa) 
Para executar as filmagens qualquer dispositivo de gravação disponível é bem-vindo, desde os smartphones às filmadoras profissionais. Mesmo as câmeras de baixíssima resolução são úteis, pois elas podem servir para simular câmeras de vigilância, por exemplo. A edição pode ser feita de diversas formas, porém, como os objetivos didáticos nem sempre se alinham às exigências da produção de vídeos profissionais, quanto mais simples a ferramenta mais rapidamente os alunos a dominarão.

Além dos programas mencionados ao discorrer sobre a produção de documentários, alguns editores merecem citação por sua completude em fornecer recursos à produção cinematográfica: Pitivi 0.95, OpenShot, Avidemux, Cinelerra-CV, Kdenlive, Apple's iMovie e Blender. Estes editores também são suficientes para saciar as necessidades das produções em geral, sejam elas amadoras ou profissionais, e são de fácil obtenção. A apresentação, por sua vez, é feita através de ferramentas bem populares: projetores multimídia (DataShow), TVs, entre outros aparelhos de reprodução de áudio e vídeo.

\subsubsection{Produção Teatral}

Independentes das modernas ferramentas digitais, porém refletindo as mudanças contemporâneas no mundo e na educação, as atividades dramatúrgicas são notavelmente defendidas por educadores desde que Henry C. Cook sedimentou seu uso como método educacional (COÊLHO, 2010). Na área de ensino de línguas não tem sido diferente, pois crescentes são as produções acadêmicas que investigam as vantagens do teatro para o ELE. De fato, o teatro e o ensino compartilham de processos e atitudes semelhantes. Quando falamos em papeis do professor (BROWN, 1994 e MÁRCIO DA SILVA \& ROTTAVA, 2015; p. 7), por exemplo, estamos admitindo que o ato de ensinar e a dramaturgia se complementam de algum modo e que podemos vê-lo sob a perspectiva filosófica do theatrum mundi, em que o mundo representa um palco onde as pessoas não passam de atores que entram e saem de cena, representando em seu tempo papéis diversos.

Essas atividades possuem em seu DNA uma valorização da prática muito útil para o ensino de línguas e costumam proporcionar aos aprendizes múltiplas oportunidades para praticarem a língua alvo. De acordo com Cook (1971), o teatro é relevante à educação porque ele é naturalmente ligado à prática e não à instrução somente. E é essa característica que encanta os professores de LE que visam uma abordagem mais comunicativa, mas que ao mesmo tempo os desafia a construir dentro das limitações educacionais uma prática teatral 
que seja realmente efetiva em fomentar a aquisição linguística, ou seja, não dispersa diante das necessidades e objetivos didáticos.

Para adequar as práticas dramatúrgicas ao contexto educacional há de se observar os dois principais modos de trabalhá-las: através da promoção de jogos de imitação (role plays) ou através de atividades que objetivam uma apresentação futura. A primeira foca mais no processo didático e busca apenas promover uma experimentação linguística desatenta a uma idealização performática. Neste caso, as possibilidades de improviso são mais abertas e seu produto é a própria prática teatral.

A segunda, por almejar uma apresentação performática no final do processo, tem um caráter mais instrucional e menos aberto a improvisos. Nela, a exigência interpretativa costuma ser maior e as atividades preparatórias buscam um ideal performático que desafia os alunos corresponderem às expectativas do grupo envolvido.

Ambas as formas são interessantes. Se, por um lado, uma permite que os alunos sejam desafiados pelas demandas linguísticas emergentes nos atos de fala, a segunda, por outro lado, os ajuda a desenvolverem habilidades de produção linguística sob os efeitos do estresse emocional causado pela exposição pública.

Holden (1981 apud COÊLHO, 2010, p. 23) mostra que os termos referentes a estes dois modos de prática teatral variam entre as culturas, mas que há uma distinção entre as atividades que visam uma preparação para apresentações teatrais públicas e as atividades de prática teatral livre:

\footnotetext{
"De acordo com Holden (1981) os termos "Drama", "Role-playing" (jogo de papéis), "teatro" e "improvisação" também são usados por pessoas diferentes e de formas diferentes. Isso pode, igualmente, levar a uma confusão sobre o que, de fato, significa cada um deles em vários contextos [...]. Segundo Holden (1981), drama é um termo genérico para todas as atividades, que envolvem o conceito de "vamos fingir". A diferença entre "drama" e "teatro", para Hoden (1981), está relacionada ao foco das atividades em sala. Assim, para o drama, o processo (o fazer) tem mais importância do que a apresentação, que é o caso do teatro. Em outras palavras, no drama, os alunos trabalham nos temas dramáticos e essa exploração das ideias e personagens da língua alvo é o que importa, eles interagem em inglês e fazem uso de várias características da comunicação oral. Os alunos têm a oportunidade de viver a experiência com a língua que estão aprendendo e o professor tem a chance de ver como cada pessoa atua no processo de interação." (1981 apud COÊLHO, 2010, p. 23).
}

O teatro também ajuda a criar eventos interessantes na escola e a aproximá-la mais de seu corpo discente e seus anseios. Normalmente os alunos demonstram muito interesse em ver seus colegas atuando e as atividades teatrais costumam mobilizar consideravelmente a 
comunidade escolar. Sabemos que no Brasil ainda há escasso acesso à cultura e que o interesse pelo teatro, principalmente entre sua população mais carente, ainda é pequeno se comparado a outros países emergentes (apesar de recentes pesquisas indicarem consideráveis avanços nessa área ${ }^{15}$ ) e que a escola tem papel fundamental em formar cidadãos mais produtores e consumidores de artefatos culturais. Desta forma, podemos considerar como inegável a importância do teatro e das artes em geral para o ensino, até mesmo porque ele costuma aliar-se às outras formas artísticas para criar sentidos.

É importante ressaltar também a exuberância interacional que atividades assim proveem. É através dessa interação que as debilidades e destrezas linguísticas se revelam e encontram suporte para o aperfeiçoamento comunicativo. Não menos importante é a forma com que elas dão voz aos alunos, permitindo que cada ente encontre seu modo idiossincrático de obter êxito comunicativo e desenvolva mais sua autoestima ao passo que se apropria desses artefatos.

Muitas dessas virtudes características da interação têm sido notadas pelos pesquisadores da área de linguística aplicada, pois contribuem para o enriquecimento das relações colaborativas entre professores e alunos, como Carmen Aranda (2011, p. 226):

\footnotetext{
"Toda pessoa traz para o ambiente de aprendizagem conhecimentos prévios, histórias de vida, conhecimentos específicos relativos a uma atividade humana, a uma forma de expressão cultural que deseja compartilhar com seus companheiros de aula. E é extremamente prazeroso para o estudante saber que o outro está interessado naquilo que tem a falar. Certamente, em uma interação didática entre estudante e professor, o primeiro sabe que não é apenas o conteúdo da discussão que está em jogo, mas também toda a questão da expressão verbal que sustenta a interação".
}

Há ainda inúmeros trabalhos acadêmicos que abordam as vantagens do uso de atividades teatrais para impulsionar a aquisição linguística, mas como elas não são o objetivo principal dessa pesquisa faço aqui apenas um reconhecimento de que as dramatizações não perdem sua relevância didática diante das demais atividades ou do advento de novas tecnologias. Tratam-se de atividades completas em si mesmas e podem também ser usadas como base laboral para outras APA, além de absorver as tecnologias em voga para aumentar suas possibilidades, dinâmicas e sua atratividade. O teatro é rico em oportunidades de

${ }^{15}$ Pesquisa Nacional sobre Hábitos Culturais realizada pela Fecomércio-RJ em dezembro de 2015. 
comunicação e oportuno para o desenvolvimento de habilidades linguísticas avançadas, sejam elas escritas ou orais. Vale dizer ainda que ele pode servir como base para muitas das produções audiovisuais citadas nessa dissertação.

\subsubsection{Ferramentas Relacionadas a estas Atividades}

O apoio às atividades teatrais é amplo na internet, sendo ela uma das principais ferramentas usadas para o compartilhamento de experiências e propostas docentes. Atualmente tem-se um banco de dados colossal de roteiros e jogos teatrais, disponíveis de forma gratuita e livre. Se antigamente os professores dispostos a estabelecer práticas teatrais tinham que adaptar as obras para não ficarem restritos a um conjunto limitado de roteiros, hoje eles encontram materiais multimodais (textos, vídeos, áudios, etc.) capazes de habilitar mesmo os mais alheios a essa forma de expressão artística a realizarem projetos de qualidade.

Há muitos textos prontos esperando apenas por professores e alunos motivados para ganharem vida, como podemos ver a seguir nos repositórios de roteiros contemplando as três línguas mais estudadas no Brasil (Quadros 5, 6 e 7). Estes foram descobertos a partir de pesquisa simples nos sites de busca e indicados aqui apenas para fins ilustrativos, já que não representam nem mesmo a ponta do iceberg das propostas disponíveis na web.

Quadro 5 - Sites de apoio à produção tetral em espanhol

\begin{tabular}{|cc|}
\hline Onenos.com & SITES EM ESPANHOL \\
OBRASDEF TEATROCORTAS & http://www.nenos.com/teatro.htm \\
http://obrasdeteatrocortas.mx & https://tramody.com/ \\
TRAMODY & https://bloguionistas.wordpress.com/descargar-guiones/ \\
\hline
\end{tabular}

Quadro 6 - Sites de apoio à produção tetral em inglês

\begin{tabular}{|c|c|}
\hline & SITES EM INGLÊS \\
\hline 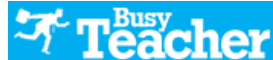 & http://busyteacher.org/classroom_activities-speaking/roleplays/ \\
\hline Drânerá & http://drama.eserver.org/plays/ \\
\hline eslflow.com & http://www.eslflow.com/roleplaysdramatheatregames.html \\
\hline
\end{tabular}

(coletados por esta pesquisa) 
Quadro 7 - Sites de apoio à produção tetral em francês

\begin{tabular}{|c|c|}
\hline \multicolumn{2}{|r|}{ SITES EM FRANCES } \\
\hline La Comédiachèue & http://comediatheque.net/theatre/ \\
\hline Dramaction & $\begin{array}{c}\text { http://www.dramaction.qc.ca/fr/textes-a-jouer-avec-vos- } \\
\text { eleves/textes-a-jouer/ }\end{array}$ \\
\hline $\begin{array}{l}\text { CONEDIES HISTORIQUES POUR LES ENFANTS } \\
\text { (destinées à être jouées par les enfants) }\end{array}$ & http://theatre.enfant.free.fr/ \\
\hline
\end{tabular}

(coletados por esta pesquisa)

Entretanto, parece-nos ser mais interessante para fins didáticos a utilização das ferramentas de informática para a criação coletiva de encenações. Roteiros originais carregam iminente autenticidade local e temporal e sua construção envolve tarefas de escrita criativa largamente conhecidas no meio educacional e reconhecidas por suas enormes vantagens à prática de ensino e aprendizagem. Nessa construção, ferramentas contemporâneas de comunicação instantânea (Whatsapp, Messenger, Skype, Hangouts, etc.) ganham mais espaço, pois é possível usá-las para tanto, através de uma construção textual gradual semelhante à comunicação em chats. É então que essa pesquisa se interessa pelo teatro, pois constatou em seus registros que os professores sempre o citam como irrefutável aliado à aquisição linguística. Percebeu-se também que muitos docentes planejam incluí-lo em suas estratégias didáticas em curto prazo.

\subsubsection{Produção de Animações}

As animações sempre foram objeto de encantamento de unânime receptividade em todas as culturas, mas por apresentarem em seu histórico tecnologias e processos muito onerosos, já que sua produção costumava demandar muito tempo de trabalho, e elevadas habilidades em artes plásticas, seu uso em APA no ambiente escolar foi por muitos anos adiado. Mesmo as técnicas mais simples, como as animações de recorte (Cut-outs Animation), de silhuetas (Silhouette Animation) e de colagem (Collage Animation) exigiam níveis de habilidades que levavam anos para serem desenvolvidas entre os alunos. Já as mais elaboradas, como as animações Stop Motion (Modelling Clay, Pixilation, etc.), só eram possíveis em estúdios altamente equipados, visto que muitas de suas ferramentas eram ainda inacessíveis para a maior parte da população.

Contrastivamente, nos últimos dez anos houve uma revolução nesse cenário provocada pelos múltiplos aplicativos e ferramentas online dedicados a transformar a 
animação em atividade corriqueira e popular. Os educadores por sua vez não resistiram às potencialidades de seu uso para fins didáticos, constatado pela expressiva produção acadêmica corrente sobre este tema, mas isso não culminou ainda em um massivo uso dessas novas ferramentas no ensino em geral. Os professores carecem ainda de mais desenvolvimento teórico e proposições didáticas que afirmem os benefícios do uso dessas técnicas para o desenvolvimento das habilidades cognitivas, comunicativas e colaborativas.

Devi (2005), por exemplo, observa que há poucos aspectos negativos relacionados ao uso de animações no ensino, além de sua produção exigir repetições visuais que podem distrair e cansar os alunos, principalmente os que têm problemas de visão (mas vejo isso como algo contornável). Entre os aspectos positivos ele lista alguns pontos de forte interesse para a linguística aplicada e o ensino em geral: aumento da motivação, diminuição da ansiedade, remoção do filtro afetivo (que prefiro ver como uma baixa no filtro afetivo), melhora da compreensão textual pela inserção de legendas ao longo da animação, auxílio à retenção de conceitos em nível superior ao uso unívoco do texto escrito e a promoção de letramentos verbais e visuais.

Dentre outras vantagens que podem ser elencadas, desde as que sublinham ganhos advindos da emergente interação entre alunos e professores às que exaltam o desenvolvimento das habilidades de adaptação linguística ao contexto, há uma que figura como lema principal da educação moderna: ela faz com que os alunos tomem posse de habilidades que anteriormente eram restritas àqueles que podiam despender recursos financeiros para tanto, ou seja, promove uma inclusão social, um empoderamento do corpo discente.

No que se refere aos ganhos linguísticos, a produção e a inserção de dublagens nas animações é também oportuna para desenvolver a pronúncia e o vocabulário da língua alvo. A dublagem pode ser feita utilizando ferramentas de síntese de voz (TTS - text-to-speech), que convertem o texto escrito em voz humana. Esse modo é interessante para experimentar vozes, que podem ganhar aspectos distintos por meio dos inúmeros aplicativos simuladores de voz existentes, ou obter-se uma noção prévia de como ficarão as animações, além de fornecer moldes de pronuncia padrão ( $B B C$ ou $C N N$ English). Contudo ele não soa muito natural ainda, produzindo áudios mais ou menos robotizados. Caso os produtores queiram deixar o áudio mais agradável e humano o caminho é fazerem os próprios alunos as dublagens. É então que tudo fica ainda mais interessante. Os alunos desenvolvem habilidades interpretativas intrínsecas às atividades de dublagem e têm suas vozes contempladas e registradas no produto. 
Outro interessante aspecto da produção de animações é citado por Butler-Pascoe \& Wiburg (2003, p. 7):

\begin{abstract}
"As multimídias fornecem as múltiplas modalidades necessárias para corresponder às necessidades dos estudantes com diferentes estilos e estratégias de aprendizado. Os aprendizes aurais, visuais, tácteis e cinestéticos têm acesso a uma variedade de atividades baseadas no computador que melhor se adéquam aos seus estilos de aprendizagem prediletos."
\end{abstract}

É oportuno destacar também que esses processos de construção de um produto audiovisual final envolvem o desenvolvimento de habilidades relacionadas à solução de problemas, tomadas de decisões, aprendizagem colaborativa e superação das dificuldades que são a base da construção do saber. Ainda, por contemplarem informações verbais e visuais elas estão alinhadas à Dual Coding Theory (PAIVIO, 1971, 1986, 1991, 2007; PAIVIO \& BEGG, 1981; SADOSKI \& PAIVIO, 2001), que propõe que a memória possui dois códigos de processamento de informações que estão interconectados, mas que ao mesmo tempo podem ser ativados independentemente. Um é o verbal, armazenado por unidades sequenciais chamadas de logogens (unidades de texto verbal ou escrito que carregam consigo impressões sonoras, significativas, de aspecto, etc.). O outro, o código visual, é responsável pela memorização imagética.

Essa teoria demonstra como um texto holístico (imagem e som) junto a seu contexto (momento, ambiente, sentimentos, etc.) é mais facilmente memorizado e ela é usada para corroborar a importância de o ensino enriquecer-se com o desenvolvimento de todo um ambiente favorável à aprendizagem. Animações, filmes e as outras produções propostas e reconhecidas nessa pesquisa apresentam uma riqueza no tratamento das questões mais relevantes à educação. Já faz algum tempo que a academia e prática de sala de aula têm embicado sua proa em direção a uma educação mais pragmática, onde o aprender conceitual não se desvincula do aprender a fazer. É produzindo algo relevante para nós mesmos que começamos a dar sentido às atividades. E é pelo envolvimento pleno nas atividades propostas que os alunos percebem o quanto elas valem a pena. 


\subsubsection{Ferramentas para a Produção de Animações}

Vista como uma das áreas atualmente mais promissoras, a animação gráfica já atingiu níveis surpreendentes de diversificação tipológica e desenvolvimento procedimental. Seguindo essa evolução, as ferramentas digitais de produção de desenhos ou animações voltadas para atender as necessidades populares têm se multiplicado na web, seduzido cada vez mais os educadores que veem nelas ótimas potencialidades para desenvolver um ensino alinhado às emergentes necessidades do mundo moderno. Desde ferramentas gratuitas a parcialmente gratuitas, a lista de ferramentas é incrivelmente extensa, mas algumas têm se destacado e chamaram a atenção desta pesquisa, seja por apresentarem interfaces e processos simplificados ou por permitirem notáveis criações pictóricas.

Entre elas vale citar os sites GoAnimate, que permite trabalhar com vários tipos de animação, atendendo desde às necessidades individuais às empresariais, Animaker, que possui as mesmas características, mas é mais acessível, pois oferece planos gratuitos e pagos, e PowToon, que apresenta interface jovial e de fácil uso. Sites para fazer apresentações visuais, como Prezi e VCasmo, também têm sido usados para fazer animações e aplicativos como ABCya, Stop Frame Animator, Animation Desk e Toontastic estão entre os mais usados para fazer animações de forma rápida e simplificada. Aliando-os aos inúmeros tutoriais disponíveis na internet, qualquer professor pode aventurar-se no mundo da animação e experimentar suas vantagens para o ensino de línguas e o desenvolvimento da expressão criativa.

\subsubsection{Produção de Programas de TV e Rádio}

As vantagens didáticas advindas da produção de programas de rádio e televisão são tão pertinentes que torna difícil compreender por que países ainda tão carentes de políticas educacionais realmente efetivas, como o Brasil, têm investido tão pouco em sua história recente para equipar as escolas de modo a fomentar a aprendizagem escolar através desses meios. Se no passado havia impossibilidades devido aos equipamentos de transmissão radiotelevisiva serem muito onerosos, hoje essa justificativa não é mais aceitável, pois chega a ser impressionante como aparelhos de longo alcance podem ser tão acessíveis.

O desafio maior não é mais a aquisição dos transmissores, senão o entendimento de que a escola precisa ser mais; representar mais como laboratório de prática que permita ao aluno apossar-se dos conhecimentos e demonstrar seu desenvolvimento por meio de sua 
produção textual multissemiótica. Para isso a escola precisa compreender melhor como o rádio e a TV são vitais para que ela se engrandeça e como utilizar dessas modernas tecnologias para desenvolver propostas didáticas capazes de formar cidadãos hábeis em se expressar de forma ampla e por múltiplos meios.

A produção radiofônica, por exemplo, têm um potencial gigantesco e pouco explorado para criar no ambiente de ensino rotinas e tarefas que desafiam os alunos a irem além da criação textual instrumentalizada. Através dela é possível debater todos os temas da atualidade, facilitando a formação de leitores e expectadores com visão crítica apurada. É possível também produzir e distribuir conhecimentos, informações e cultura, além de permitir que os alunos gerenciem sua programação e encontrem nessas atividades espaço propício para a expressão de suas ascendentes ideologias e para a promoção de diálogos com os fatos e dilemas que chamam a atenção da nação.

O rádio tem o poder de criar situações comunicativas estimulantes e ensaísticas que promovem um expressivo desenvolvimento na língua alvo (ODERA, 2008) e diversos estudos e experiências ao redor do mundo evidenciam essas características agregadoras para o ensino. Performances sobressalentes em comparação com grupos desprovidos de atividades assim também têm sido constatadas (TILSON et al, 1991; LEIGH \& CASH, 1999). Ele também é propício para a prática da aprendizagem centrada no aluno e ajuda os educadores a abraçarem novas abordagens, inovações e desenvolver o pensamento pedagógico (ANZALONE \& BOSH, 2005). O fato relevante é que a produção e a interação radiofônica são comunicações elaboradas e dominá-las na escola é imprescindível para a educação em geral.

Não menos interessante para o ensino e compartilhando das mesmas vantagens citadas, a produção televisiva também possibilita grandes evoluções nos processos de ensinar e aprender. Vale ressaltar que as produções audiovisuais necessitam de meios para ganharem publicidade e servirem como vitrine do que se está sendo feito na escola. É então que investir em transmissões radiotelevisivas torna-se essencial, pois elas servem para valorizar os projetos mais proeminentes ao honrá-los em sua programação e, obviamente, para apresentar programas e informações de interesse educacional.

Entretanto, ainda não há muitos exemplos notáveis de escolas que encontraram na produção/transmissão radiotelevisiva um aliado para estimular a integração do aluno com a instituição e o aperfeiçoamento das estratégias didáticas. Há sim muitas pesquisas que contemplam as vantagens do uso de produções televisivas para o ensino presencial e a distância, principalmente o uso de programas educacionais (CCT, 2004). Mas isso não é suficiente para os alunos entenderem e dominarem os processos de construção de programas 
de rádio e TV e assim desenvolverem um modo mais criticamente ativo diante do poder de influência desses meios. É fato que o rádio perdeu muito sua função social nos últimos dez anos e que a audiência televisiva também é cada vez menor, mas ainda figuram como fonte principal de acesso a informações para a maior parte da população, ou seja, saber pela prática como são feitos esses programas e como é possível manipular os textos escritos e visuais é imprescindível para a formação de cidadãos capazes de pensamento crítico livre.

O fato principal é que as ferramentas de produção e transmissão audiovisual estão cada vez mais acessíveis (KAYMAS, 1999) e a escola tende também a dominá-las cada vez mais - aumentando assim seu valor comunitário, pois através dela podem ser feitas muitas políticas de estado além das que já estão em curso, e sua função social, já que a escola tem potencial maior de servir a uma comunidade. Há tempos que a pedagogia tem percebido que a escola pode significar mais para os alunos e a comunidade em que está inserida, pois é a partir dela, principalmente, que a sociedade se desenvolve culturalmente. Mas sua influencia social é diminuta se ela não estiver presente nos meios de comunicação ou não atuar na organização e na divulgação de conhecimentos e informações imprescindíveis para que a população possa exercer seus direitos e conhecer seus deveres fundamentais para o exercício da cidadania.

\subsubsection{Ferramentas para a produção e a transmissão radiotelevisiva}

Os materiais audiovisuais produzidos pelos alunos normalmente ganham voz na própria escola, ora pela sua replicação nas aulas de professores que perceberam algum valor didático, já que representam amostras genuínas da língua alvo em uso experimental, ora em eventos culturais temáticos que as escolas costumam promover para fins diversos. Contudo, no mundo altamente informatizado em que vivemos as possibilidades de transmissão remota de áudios e vídeos são imensas e giram em torno das ferramentas de hospedagem virtual de dados, como algumas citadas neste trabalho, e sites de armazenamento em nuvem (Google Drive, SkyDrive, Dropbox, Ubuntu One, iCloud, Box, SugarSync, etc.). Elas permitem o acesso livre a todos os públicos ou restrito a um grupo específico e carregam informações sobre quantidades e qualidades das visualizações, facilitando a coordenação dos projetos e a escolha do público alvo, considerando que todo material audiovisual deve obedecer a diretrizes éticas relacionadas à exposição dos alunos.

A produção de programas radiotelevisivos encontra toda uma gama de informações e recursos destinados a capacitar os mais leigos a criarem roteiros e estratégias de interação 
com o público e, devido a sua semelhança com as demais produções audiovisuais, compartilha com essas atividades ferramentas e processos. Apesar de a TV e o Rádio serem apenas meios pelos quais essas produções podem ser teletransmitidas, sua organização, gerenciamento e transmissão envolvem atividades estimulantes ao domínio verbal e visual e são visíveis as vantagens que a implantação de emissoras radiotelevisivas nas escolas pode fornecer à educação, pois ela cria demandas que motivam a produção de textos multimodais, oportunizando aos alunos o desenvolvimento das habilidades comunicativas e a aprendizagem colaborativa.

Vale também citar que há sites de criação radiofônica (Spreaker.com, Radionomy.com, Grooveshark.com, Dyb.fm, etc.) e televisiva (UStream.tv, Stickam.com, $w w w . b l i p . t v$, youtube.com, etc.) capazes de suprir a necessidade de transmissão a partir da escola, já que nem todas escolas podem investir em aparelhos transmissores ou priorizar esses tipos de atividades. Tais propostas têm sido estudadas por alguns gestores das escolas estudadas por esta pesquisa e, a princípio, a maioria dos educadores é favorável a uma maior inclusão das práticas comunicativas advindas de atividades de produção radiotelevisiva, já que elas funcionam como motores para a instalação de rotinas integradoras entre alunos, professores, habilidades e conteúdos. Em uma das escolas (CILC) observou-se a instalação de aparelhos de reprodução auditiva de grande alcance para a realização de intervalos musicais, onde os alunos podem conhecer melhor as canções em destaque nas diversas línguas estudadas e serem informados sobre os eventos e normas da escola. Eis uma demonstração de que há escolas que podem investir na aquisição de aparelhos, desde que justificada pela elaboração de projetos interessantes à educação.

\subsubsection{Produção de Música e Dança}

A música sempre esteve muito presente nos cursos de idiomas. É praticamente impossível encontrar um professor de línguas que não a tenha utilizado como proposta didática exemplificativa de algum uso linguístico em voga. Porém, a inclusão da música em sala de aula costumava ser muito passiva, representando apenas uma apreciação de estilos, versos e sonoridades. Atualmente, devido ao surgimento de ferramentas facilitadoras da produção musical, já é possível que mesmo os mais ineptos aos fundamentos e instrumentos musicais façam música, visto que ela é tradicionalmente definida apenas como uma “combinação de sons”. Seu uso no ensino é importante, pois a versificação estimula a criatividade e os wordgames (atividades em grupo de criação poética, incentivadas 
especialmente por Bates, 1993, entre outros), que podem ser muito úteis para estimular a compreensão e a produção poética nos alunos.

$\mathrm{Na}$ maioria das vezes relacionada à música, a dança também possui grande aceitação entre os alunos, mas é menos utilizada em sala de aula, provavelmente por não ser vista ainda como estratégia relevante à aquisição linguística. Contudo, há exemplos de uso da dança no ensino de línguas (como em RUIZ, 2010) e, como a dança costuma estar presente em apresentações teatrais, filmes, etc., é válido que ao pensar em produções audiovisuais ela seja incluída como proposta potencialmente interessante para o ensino, principalmente devido às coreografias estarem frequentemente acompanhadas de linguagem instrucional, procedimental, coordenativa, etc. Barrozo (2015) cita um exemplo de como a dança (aliada tradicional do teatro) pode ser utilizada em sala para estimular a fixação de vocabulário pela criação de demandas mnemônico-cinestésicas:

\footnotetext{
"Por exemplo, que tal ensinar as partes do corpo por meio de instruções de dança? $\mathrm{O}$ professor pode inventar coreografias em que o aluno tenha que repetir seus movimentos ou seguir instruções e pratique a expressão oral dizendo em voz alta o que está fazendo ou respondendo a enigmas. Que tal aprender a pedir e a dar informações por meio de encenações teatrais? Em atividades assim, o aluno se vê em um contexto simulado de imersão e percebe a língua em movimento, suas necessidades dinâmicas de adequação e de criação de microcontextos, ao invés de ser meramente exposto a textos de diálogos, muitas vezes criados em laboratório e nem sempre refletindo a comunicação real, e esperar que um dia seja colocado em uma situação em que a lembrança daquele diálogo lido em sala possa ajudá-lo de alguma maneira" (BARROZO, 2015, p. 7).
}

Logo, tanto coreografias quanto composições experimentais podem ajudar os alunos a compreenderem melhor a língua em uso, suas possibilidades comunicativas e aspectos paralinguísticos. Podem ainda fazer parte de outras produções audiovisuais ou servir de pretexto para a abordagem de temas variados de interesse do ensino. Em ambas as escolas observadas foi percebido um amplo uso desses recursos. No CILC, dois projetos se destacam devido a seu poder de envolvimento junto aos alunos: o Projeto Ídolos, que promove um concurso de música onde os alunos podem aventurar-se em karaokês e audições originais, e as já descritas atividades coreográficas encenadas pela informante Marisa. Já no CILT, um projeto que incentiva os alunos a pesquisarem, ensaiarem e fazerem apresentações ao vivo de canções estrangeiras durante os intervalos se mostra muito interessante, pois incentiva os alunos a conhecerem mais a tradição musical de cada país e, é claro, a desenvolverem mais suas habilidades linguísticas. 


\subsubsection{Ferramentas relacionadas a essas atividades}

Entre os aplicativos de produção musical mais interessantes, devido a suas interfaces simples e usabilidade descomplicada, destacam-se: Music Maker Jam, Figure, Sing! Karaoke, Loopimal, Scape, Ninja Jamm e Garage Band. Para projetos mais ambiciosos recorre-se a programas já consagrados, como Audacity, Nuendo, Pro Tools, Adobe Audition, Cubase e Acid. Entre os sites que permitem livre experimentação musical, estão listadas no Quadro 8 algumas opções:

Quadro 8 - Ferramentas de Livre Experimentação Musical

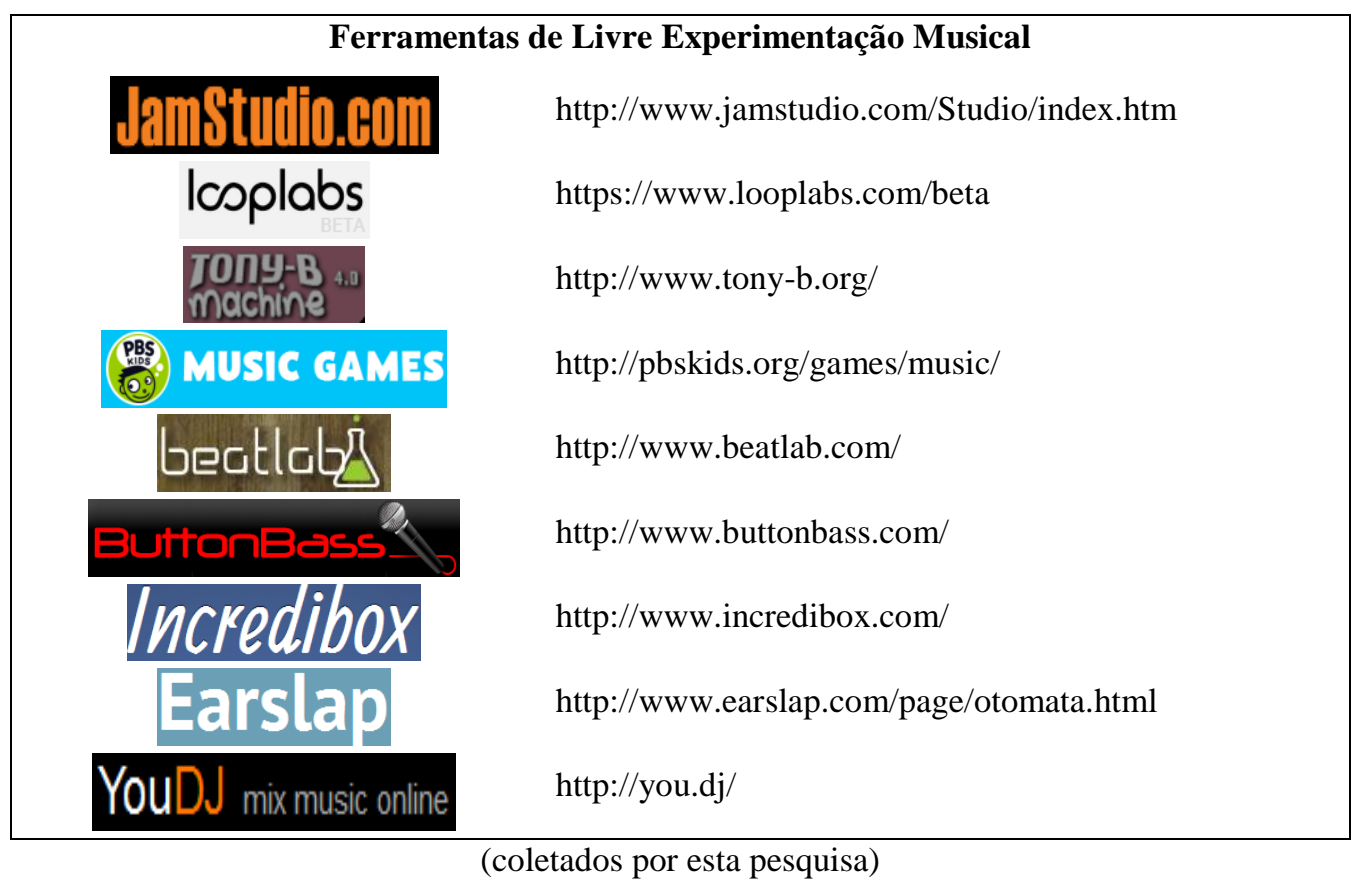

A livre experimentação musical está cada dia mais acessível aos alunos graças a ferramentas digitais como estas que permitem que leigos de qualquer idade possam produzir conteúdos musicais para atender a objetivos relacionados a atividades escolares que estimulam a comunicação através da música, por exemplo, ou mesmo a objetivos lúdicos individuais.

Para apoiar os projetos de dança há também aplicativos que prometem ensinar qualquer um a dançar qualquer estilo, como o Learn Dance e o IDance, por exemplo, mas atividades de livre criação coreográfica e jogos de movimentação corporal parecem ser mais interessantes para o ensino, pois não geram preocupações performáticas que podem causar ansiedade. O fato é que esse campo carece ser muito mais explorado, pois ainda não se sabe ao certo o quanto e como as atividades coreográficas podem contribuir para a ALE, já que há 
ainda pouca produção acadêmica a esse respeito. Não obstante, é possível encontrar na web alguns exemplos de sucesso (como as experiências de ensino de gramática através da dança descritas por Aidan O'Kelley em https://www.teachingchannel. org/ videos/teachinggrammar-with-dance) e, a partir dessas inspirações, ser mais um a contribuir com o desenvolvimento dessa área ainda pouco explorada.

\subsubsection{Oficinas de Escrita Criativa}

Apesar de todas as metamorfoses que os modos de comunicação têm sofrido nos últimos anos, o texto escrito mantém-se atual e indispensável para a elaboração de projetos e instruções em geral. Nas produções audiovisuais não tem sido diferente. As habilidades escritas permanecem como base para a construção dos roteiros e para o registro das eventualidades dignas de tomada de nota. Por suas características permanentes, é através delas que se obtém uma tese narrativa ou escopos argumentativos mais rígidos e os confrontam com as possíveis ideias emergentes no grupo producente (antíteses), resultando em uma versão sintética do que foi construído coletivamente. Para tanto, as oficinas de escrita são fundamentais, pois o domínio textual, principalmente, é que permite que um trabalho audiovisual se desenvolva e ganhe notoriedade.

Para desenvolver essas habilidades os professores costumam promover intervenções didáticas ideologicamente distintas, seguindo seus modos particulares de ver o processo de escrita e as habilidades que devem ser mais valoradas. Segundo HYLAND (2003), os professores adotam uma ou mais orientações para promover o desenvolvimento da escrita junto aos alunos de L2 e elas circulam ao redor de seis focos principais, conforme descritos de forma sintética a seguir:

1) Foco nas estruturas linguísticas: desde uma concepção behaviorista e estruturalista de língua, essas abordagens valorizam textos que seguem uma formalidade construtiva e apresentacional. O conteúdo é deixado de lado para avaliar o domínio das regras e escolhas vocabulares, promovendo um processo de imitação e manipulação textual de forma a atingir um texto sintaticamente perfeito e preciso.

2) Foco nas funções textuais: seguindo também uma visão estruturalista, essa orientação valoriza as sentenças bem conectadas e acredita que seguir certas regras é 
suficiente para que os escritores se expressem de maneira efetiva e completa. $\mathrm{O}$ foco está em como as estruturas se relacionam com os sentidos e, a partir de formas prescritas e tarefas baseadas em padrões formais, espera-se que o aprendiz desenvolva uma organização textual necessária à precisão comunicativa.

3) Foco na expressão criativa: a partir da perspectiva de que escrever é algo que se aprende mais do que se ensina, essa abordagem visa promover o aprendizado através de produções autênticas em que o aprendiz possa expressar sua voz de maneira mais livre e praticando uma descoberta mais autônoma dos modos escritos. "As aulas são organizadas ao redor das experiências e opiniões pessoais dos alunos e a escrita é considerada como um ato criativo de autodescoberta" (HYLAND, 2003, p. 8). Evitando impor modelos, pontos de vistas ou apresentar respostas de antemão, os professores praticam uma atitude responsiva à produção dos alunos, aproveitando para instruí-los e contestar suas ideias, ao invés de aterem-se apenas aos erros formais (MURRAY, 1985).

4) Foco no processo de escrita: a partir da observação de que os escritores novatos planejam menos suas composições escritas e tomando como referência a expertise dos que usam o texto escrito para organizar ideias e problemas de modo a promover análises, gerar reflexões e, consequentemente, aperfeiçoá-lo, essa orientação busca desenvolver habilidades de gerência textual baseadas em um ciclo virtuoso de planejamento, escrita e revisão (FLOWER, 1989; FLOWER AND HAYES, 1981). O professor atua estimulando brainstorms, esboços, esquemas e refinamentos de ideias, evitando muita ênfase na forma. A escrita é vista como um processo sinuoso, exploratório e gerativo por onde os escritores descobrem e reformulam suas ideias para aproximar-se do sentido pretendido (ZAMEL, 1983).

5) Foco no conteúdo: aproveitando o desejo dos alunos em posicionar-se diante dos mais variados temas que polemizam a vida moderna, desde as demandas de 
sustentabilidade motivadas pelas mudanças ambientais até a qualidade das opções pessoais, essa abordagem visa promover um estudo dos temas eleitos e produções significativas a respeito deles. A pesquisa vocabular intrínseca ao tema, discussões de textos e eventos relacionados a ele, brainstorms ${ }^{16}$ e estratégias de organização das ideias ( schemata $^{17}$ ) são comuns e buscam promover um maior domínio sobre o tema em questão, anterior à sua apresentação formal.

6) Foco nos gêneros: a ideia de que cada texto visa atingir um propósito especifico orientado pelos objetivos comunicacionais em contexto e não pelos padrões reguladores característicos de apenas um dos modos comunicativos, como é o caso dos textos formais, muitas vezes é negligenciada nas oficinas de escrita. Estudar esses gêneros, ou seja, as diferentes linguagens empregadas em contextos próprios, nos ajuda a repensar o efeito comunicativo dos textos produzidos e como são construídas as relações sociais capazes de exigir, pelo menos de forma implícita, que um determinado texto atenda a requisitos além dos conteúdos, processos e formas. É isso que propõe essa abordagem: capacitar os aprendizes atingirem um objetivo comunicativo alinhado às possibilidades textuais do modo de expressão em que se está inserido, praticando negociações de sentido que são inevitáveis para a obtenção de êxito.

Cada orientação didática tem sua razão de existir e apresenta exemplos exitosos dentro de seus parâmetros. É importante observar também que o que os professores normalmente praticam é uma abordagem multifocal, ora focada no escritor e sua capacidade de manipulação textual, ora focada no texto, seu conteúdo, contexto, função ou forma. Ela permite que os professores correspondam às diversas necessidades e possibilidades

\footnotetext{
16 Também chamado de tempestade de ideias, brainstorm é mais que uma técnica de dinâmica de grupo, é uma atividade desenvolvida para explorar a potencialidade criativa de um indivíduo ou de um grupo colocando-a a serviço de objetivos pré-determinados.

17 Schemata, ou mapas cognitivos, são valores, crenças e papéis atualizados pelo indivíduo por assimilação ativa. Uma vez em contato com uma cultura, seja de uma sociedade, organização ou grupo social, o indivíduo irá assimilar seus elementos e reconstruí-los internamente.
} 
comunicativas, aumentando assim a abrangência de seus cursos. Permite ainda que os objetivos pessoais sejam satisfeitos, pois os alunos costumar apresentar diversidade no modo como compreendem a língua e sua função utilitária dentro de suas expectativas comunicativas, conforma Hyland (2003) defende:

\footnotetext{
"Eu tenho frisado que as aulas de escrita em L2 são tipicamente uma mistura de mais de uma abordagem e que os professores frequentemente combinem essas orientações de forma imaginativa e criativa [...]. A escrita é uma atividade sociocognitiva que envolve habilidades de planejamento e esboço, assim como conhecimento da língua, dos contextos e do público a que o texto se destina." (HYLAND, 2003, p. 23)
}

Nas oficinas de escrita criativa, a potencial riqueza didática advinda da adoção de abordagens multifacetadas não deve ser negligenciada. Como elas são aqui propostas para fins didáticos, podendo figurar como parte de um projeto de produção audiovisual, é válida também a observação de que mesmo a forma pode ser aprendida e ensinada através de produções sobre ela, colocando as habilidades criativas e construtivas em patamar superior à precisão estrutural. Por exemplo, é possível que, ao produzirem algo sobre questões metalinguísticas, os alunos descubram os valores da norma culta e encontrem um valor utilitário maior para seu produto, usando da pesquisa e da reconstrução informacional em semioses diversificadas, pois ele pode servir tanto para o desenvolvimento pessoal como de material didático para outrem. Nessa mesma linha, Paran (2006) observa que se tem esperado que os alunos de L2 aprendam a escrever academicamente ao invés de criativamente, modo este que ele também considera ideal.

Portanto, as abordagens que valorizam o processo de aprendizagem através da experimentação livre e de revisões guiadas são muito bem-vindas ao ensino de LE, mas isso não quer dizer que as que supervalorizam a forma devem abandonadas, já que é o tipo de produção que dirá como o texto deverá se comportar. Um vídeo comercial, por exemplo, permite maior uso da linguagem coloquial e de jogos de palavras. Já um vídeo institucional, por sua vez, costuma atender mais às exigências da norma culta. Isso desafia o professor a lidar com o foco na forma, pois ele está frequentemente em contraste com o foco no sentido proposto pelas abordagens comunicativas (LITTLEWOOD, 2004).

O equilíbrio entre o bom senso e liberdade composicional tende a ser a regra mais importante em produções criativas para que o produto audiovisual seja irrepreensível quanto a seus conteúdos e modos de apresentação, pois ele denota um registro público do que foi construído em ambiente escolar e deseja-se que esteja alinhado aos objetivos político- 
pedagógicos. Como nada que é feito na escola deve estar isolado dos anseios da sociedade, é possível que um texto audiovisual com linguagem muito coloquial ou com deficiências em relação à norma padrão seja malvisto ou malquisto pelos que acompanham o ensino, mas isso pode ser contornado com notas explicativas e atitudes instrucionais com o grupo participante. E como o ensino de LE tradicionalmente visa preparar o indivíduo a usar a língua em contextos formais é previsível que haja pressões contra trabalhos muito livres, mas deve-se ter em mente que nas produções escolares em geral o processo é mais importante que o produto, ou seja, falhas, inconsistências ou impropriedades no produto audiovisual não significam que os alunos não as superaram no processo produtivo.

Um fator imprescindível para que a escrita criativa aconteça da melhor forma possível é que as atividades propostas sejam realizadas com limitações de tempo e extensão mais flexíveis. O aluno precisa buscar inspirações no mundo exterior à sala e, preferencialmente, livre das constrições que normalmente as atividades de redação propostas em sala de aula exigem, como quantidades mínimas e máximas de linhas escritas, encomendas temáticas, controle de modos e duração, entre outras limitações. Caso isso não seja possível, deve-se pelo menos buscar criar um ambiente favorável à produção, pois alguns alunos provavelmente precisarão de ajuda para iniciar uma redação ou em sua escolha temática. Isso pode ser feito por meio de brainstorms e discussões, pois ajudam o amadurecimento das ideias e a encontrar o leitmotiv do texto. Para permitir essa abordagem plástica em relação à construção textual é conveniente o uso de ferramentas de apoio à escrita que possam permitir o controle não presencial e colaborativo, de modo a dinamizar as tarefas, reduzindo o tempo de feedback e auxiliando o engajamento do aluno.

\subsubsection{Ferramentas de apoio à escrita criativa}

Além das ferramentas comumente usadas para edição de textos em geral, há algumas que merecem destaque por proverem recursos atrativos à criação de contos ilustrados, histórias em quadrinhos (HQs), poesias, etc. Elas auxiliam a engajar os alunos com suas interfaces estimulantes, possibilitando um produto final de alto nível de elaboração capaz de nutrir um sentimento de realização pessoal nos participantes, pois é esse normalmente o combustível principal dos autores de renome.

Alguns alunos já demonstram um interesse natural produzindo HQs, por exemplo, de forma autônoma e outros só precisam de um impulso para descobrirem o quão fascinante 
pode ser a criação de personagens, tramas e desfechos ou simplesmente a livre expressão de ideias, pensamentos e ideologias. É então que os professores podem encontrar em ferramentas digitais, como as listadas no Quadro 9 a seguir, um poderoso aliado para dinamizar suas aulas e praticar instruções de escrita mais adequadas às necessidades de cada aluno.

Quadro 9 - Ferramentas de apoio à escrita criativa

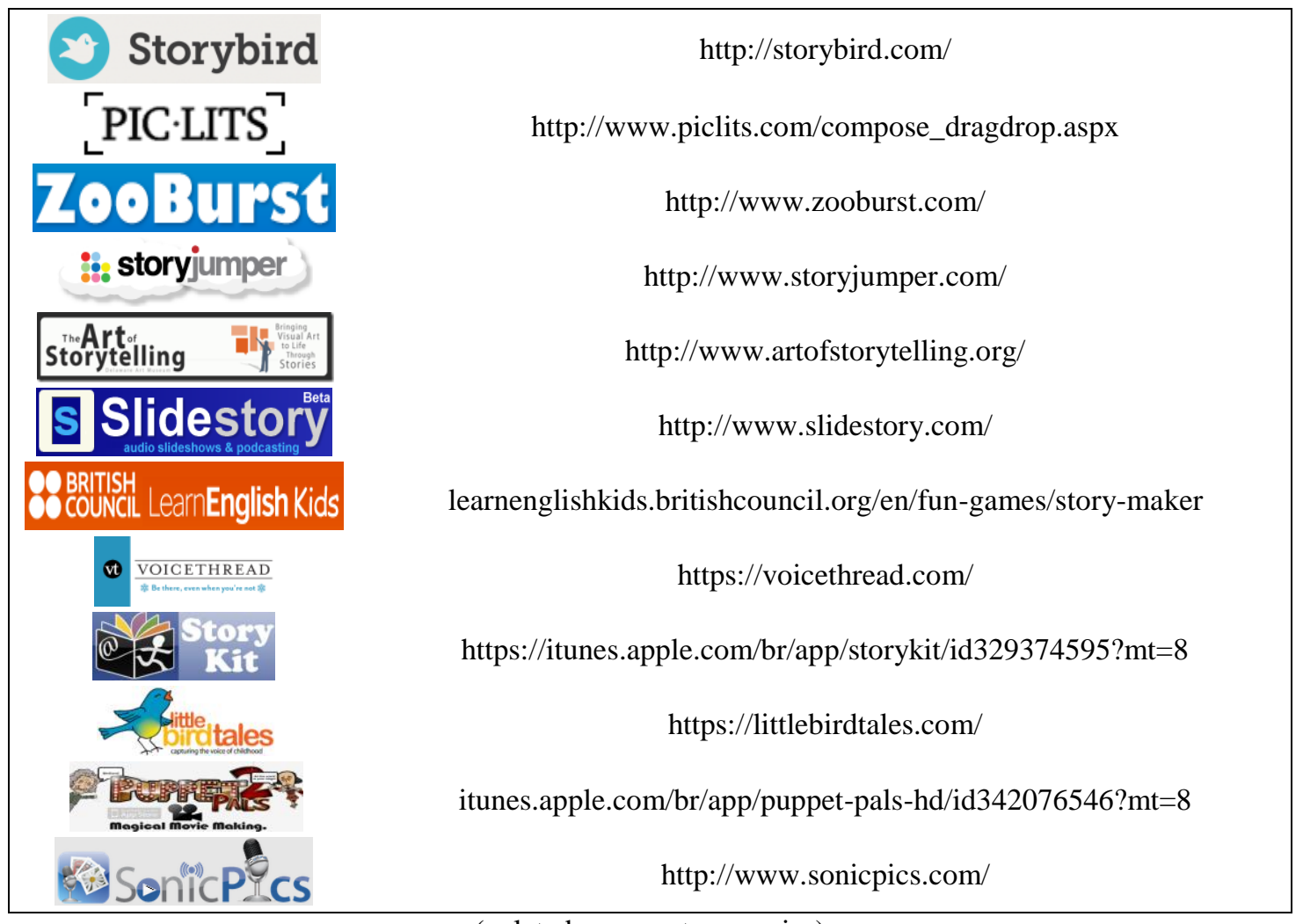

(coletados por esta pesquisa)

Entre elas, a primeira (storybird) se destaca por suas propriedades ímpares para estimular a escrita criativa. A partir da colaboração de ilustradores ao redor do mundo, essa afamada ferramenta inspira os escritores novatos há alguns anos e possibilita aos professores coordenar atividades de escrita integradas à uma infinidade de ilustrações. Já é amplamente usada no lócus dessa pesquisa, onde foi possível observar alguns significativos trabalhos produzidos pelos próprios alunos, conforme o exemplo da Figura 6, feito por um aluno do professor Gerson Moura e disponível integralmente para leitura, junto a muitos outros, no site http://eflcilt.blogspot.com.br/p/j2-books-written-by-j2-students.html. 
Figura 6 - Amostra de produção usando a ferramenta storybird
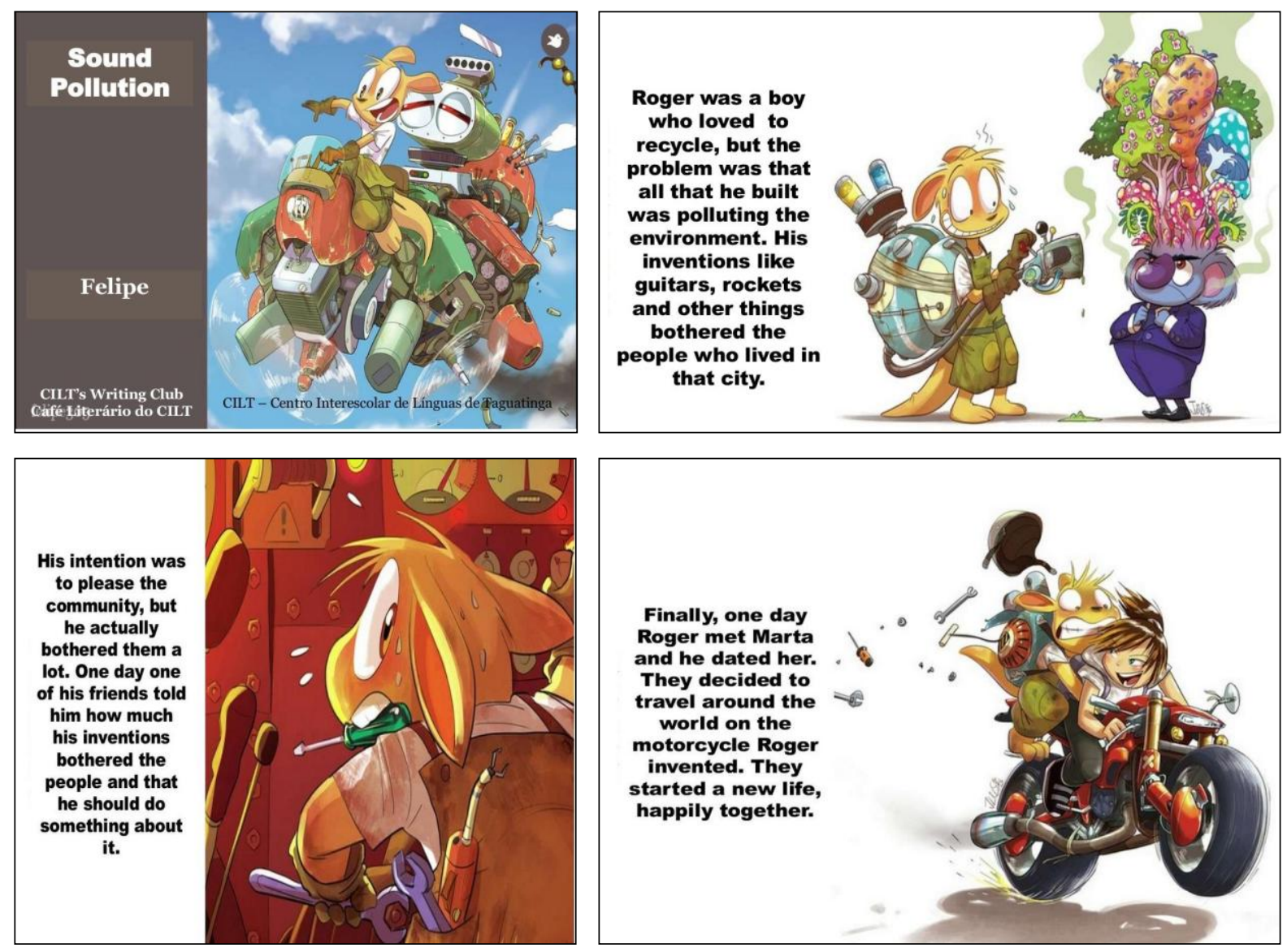

(Imagem cedida pelo professor Gerson Moura)

Observa-se nesse exemplo que foi dada uma abertura à livre expressão, permitindo o aparecimento de inconsistências ou equívocos linguísticos que oportunizam ao aprendiz uma aprendizagem mais marcante ao passo que segue as instruções corretivas do professor. Isso se dá porque em atividades assim o aluno pratica operações de comunicação adaptativas aos modos da língua alvo, descobrindo possibilidades e divergências entre as línguas e encontrando seu modo idiossincrático de expressar-se.

Talvez esse seja um dos principais desafios ao aprender uma língua estrangeira: encontrar sua voz própria na língua estudada, pois mesmo na L1 os falantes apresentam diversidades de pronúncia, ritmo, eloquência, léxico, sotaque, etc. Cada indivíduo tem um repertório próprio e através de escolhas linguísticas particulares expressa-se, refletindo sua base sociocultural e sua competência comunicativa. Essa expressividade é aprimorada segundo as experiências de comunicação que lhe foram oportunizadas pelos diversos tipos de interação existentes na vivência social. 
Outras ferramentas que estimulam a experimentação comunicativa por meio da escrita merecem citação, como é o caso dos sites voltados para a criação de HQs ou charges. Elas possibilitam que mesmo os desprovidos de habilidades de desenho possam aventurar-se por essa arte sem necessidade de muitas instruções prévias. Essa característica sublinha sua utilidade para o ensino, pois facilita o foco na construção textual das histórias e não minam o entusiasmo dos alunos com atividades muito trabalhosas. O produto é rapidamente obtido, auxiliando os escritores a criar histórias mais consistentes e a cumprirem os prazos do curso em tempo hábil para receberem o feedback docente. A seguir uma lista das mais conhecidas:

Quadro 10 - Ferramentas para a criação de histórias em quadrinhos (HQs)

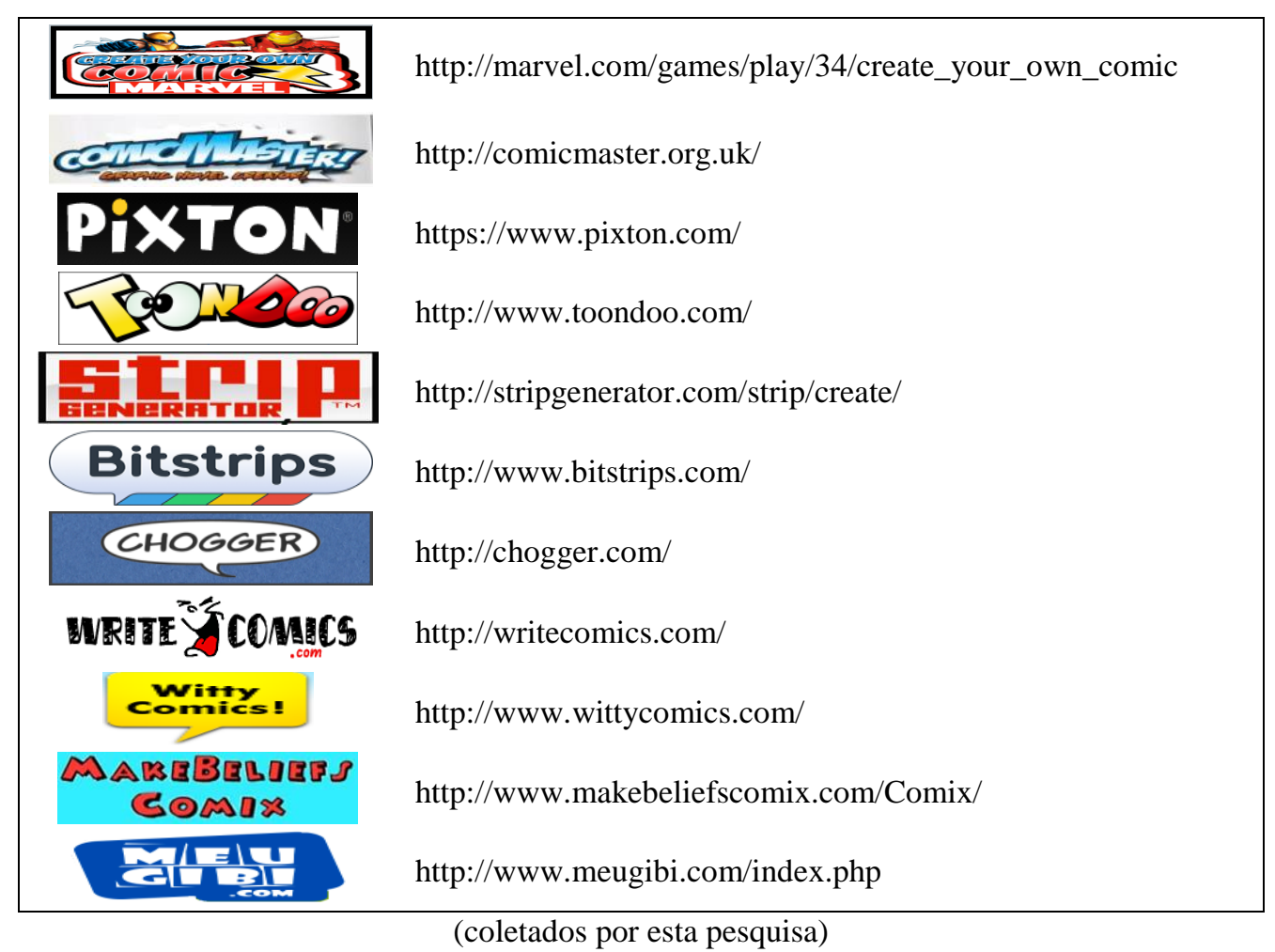

Há também ferramentas profissionais para os que querem dar um passo adiante e criar HQ's mais elaboradas, como os programas Manga Studio, StrechBook Pro, Adobe Photoshop CC, Comic Creator, Poser Pro, Corel Painter, Motion Artist, Pixton, Comic Life, Final Draft e Anime Studio Debut. Como muitos escritores renomados, como Neil Gaiman e Alan Moore, descobriram seu talento aventurando-se em esboços rudimentares e posteriormente absorvendo ferramentas mais refinadas, é provável que no futuro algumas escolas se transformem em célebres produtoras de conteúdos audiovisuais ou que pelo menos formem grandes expoentes artístico-pedagógicos. Por isso acreditamos que a produção audiovisual 
será a grande responsável por uma provável ampliação do papel da escola na sociedade a partir do surgimento de verdadeiros laboratórios de interação e produção multissemiótica.

\subsubsection{Ferramentas de Suporte à Autonomia}

Vista como habilidade de assumir a responsabilidade do próprio aprendizado, determinando objetivos, monitorando o processo de aquisição e avaliando os progressos (HOLEC, 1981), a autonomia no aprendizado é um desejável talento que professores podem encorajar em seus alunos, uma vez que ela é exaltada por muitos teóricos (vide BORG \& ALBUSAIDI, 2012) por sua capacidade de melhorar a qualidade da aprendizagem, promover sociedades democráticas, preparar os indivíduos para a aprendizagem ao longo da vida, etc. Tal destreza no aprendizado é indispensável quando se defende a produção discente de textos multissemióticos para fomentar a ALE, pois sugere que o aluno estará envolvido em atividades que demandam seu engajamento em processos criativos ou adaptativos de manipulação textual e instrumental.

Para promover atitudes mais autônomas por parte dos alunos faz-se necessário o conhecimento e a indicação de toda uma gama de recursos que possam instruí-los em tarefas ou satisfazê-los em sua busca pessoal por exploração linguístico-comunicativa. Atualmente, há todo um universo digital com ferramentas que se propõem tanto a competir com o ensino instrucional quanto a apoiá-lo e cabe aos interessados o exame de quais podem ser úteis e quais apresentam pouca efetividade. O que importa para os cursos de idiomas é que tanto professores como alunos podem usufruir desse ambiente digital para executar seus projetos de forma mais dinâmica e interagir com diversos outros profissionais e tecnologias.

Em sites de exposição audiovisual livre, como "Youtube", "Vimeo", "Yahoo! Screen", "DailyMotion", "Hulu" e "Vube", ou em sites de videoaulas, como os nacionais "eUnicamp", “e-Aulas USP”, "Unesp Aberta”, "Portal de Videoaulas da UFF”, "FGV - Ensino Médio Digital", "Veduca", "Me Salva", "Você aprende agora", entre outros, e os internacionais "edXCousera", "Khan Academy", "MIT Video", "Stanford Online", "Harvard Extension School", por exemplo, há inúmeras aulas e palestras sobre os mais variados temas e a cada dia surgem novas aulas e sites dedicados a abordar questões de sala de aula. Neles os alunos podem encontrar informações sobre praticamente tudo que esteja relacionado aos objetivos escolares. O corpo docente também pode fazer uso dessas videoaulas de forma a complementar suas instruções, desenvolver suas reflexões ou instruir-se, pois a disposição 
para absorver uma ferramenta nova em suas estratégias didáticas deve estar acompanhada de atitudes autônomas também por parte dos professores.

"Professores genuinamente exitosos têm sempre sido autônomos no sentido de terem
um forte senso de responsabilidade pessoal com seu ensino, exercitando pela
reflexão contínua e pela análise os graus mais altos de controle afetivo e cognitivo
do processo de ensino e explorando a liberdade que isso confere." (LITTLE, 1995,
p.179)

Como a produção audiovisual requer o desenvolvimento de algumas habilidades básicas - em alguns casos até uma expertise no uso de editores gráficos e textuais - é fundamental que o professor também tenha essa ousadia autônoma tanto para conhecer ferramentas novas como para absorver suas funcionalidades. Esta é uma forma de atualização profissional que abre espaço para o aperfeiçoamento e a modernização de seus cursos. Também, é algo substancial para responder às emergentes aspirações dos alunos, já que estar atualizado em relação ao universo cultural das novas gerações permite que ele desenvolva aulas mais atrativas e motivacionais, podendo recorrer a temas e símbolos relevantes às áreas de interesse dos alunos.

Uma tendência moderna é o uso cada vez maior de programas e sites destinados ao ensino de idiomas. Sites de consulta vocabular e tradução são comuns e estão entre os mais acessados no meio acadêmico, dispensando citação. Sites que buscam ensinar fórmulas e itens linguísticos por meio de interfaces interativas ou jogos, como "Livemocha", "Duolingo" e Menrise (links a seguir junto a algumas outras opções), também possuem notoriedade ao buscarem corresponder a algumas necessidades comunicacionais individuais através do meio digital.

Alguns sites também têm suas versões em aplicativos para tablets e smartphones e há outros para adultos e crianças que prometem a mesma eficácia: "LinguaLeo", "Babbel", "duolingo", "Rosetta Stone", "Voxy", "How to Say", "Speak English", "Na Ponta da Língua", "Mindsnacks", "EF My Words", “Acella Study", "Human Japanese”, “Allods Online" etc. E não se deve esquecer dos inúmeros vocabulary builders (programas para expandir o vocabulário): "Vocab Builder", "Words, words, words", "Dictionary.com Flashcards", "Vocab Word Game" etc. 
Quadro 11 - Sites para aprender idiomas

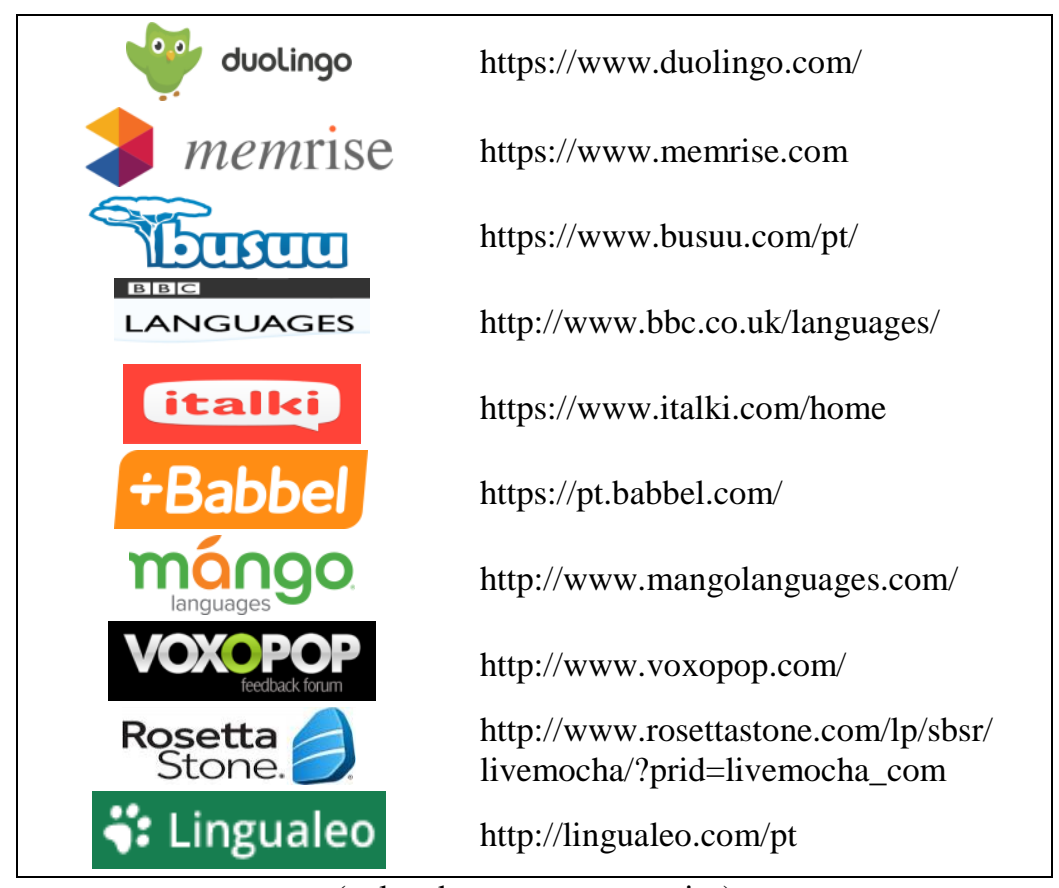

(coletados por esta pesquisa)

Em meio a tantas possibilidades, os ambientes virtuais multiusuários (multi-user virtual environments - MUVE) estão se multiplicando e uma ferramenta que provê um MUVE bem atrativo e com ardente potencial para oportunizar aos alunos uma prática comunicativa autêntica e significativa tem chamado a atenção acadêmica: Second Life. Entre outros semelhantes, como OpenSimulator, Project Wonderland, etc., este aplicativo permite uma interação textual, visual e oral por meio da escolha identidades virtuais ("avatares") entre pessoas do mundo inteiro e o engajamento em atividades tanto individuais como grupais além de figurar como uma tendência da vida moderna, visto que as interações pelos meios virtuais estão substituindo grande parte das interações presenciais.

Por suas propriedades fascinantes ao meio educacional, incontáveis universidades e escolas a estão adotando como ferramenta pedagógica (SALT, ATKINS \& BLACKALL, 2008) e entre muitos benefícios para o ELE que têm sido observados no meio acadêmico vale citar alguns principais (baseados em WARBURTON, 2009):

- Oferece oportunidades para interação social entre um grupo de pessoas e suas comunidades;

- Provê aos usuários conteúdos lúdicos e criativos, às vezes inacessíveis na vida real por serem onerosos, distantes, elaborados ou de difícil acesso; 
- Oferece oportunidade para o reconhecimento e o aprendizado de outras culturas;

- Torna a imersão em ambiente tridimensional simples e cria uma forte impressão de "estar presente";

- Fornece contextos simulados considerados vantajosos para os propósitos educacionais;

- Reduz a ansiedade de performance, pois reduz a exposição dos alunos (HUNDSBERGER, 2009);

- Cria uma nova possibilidade de interação entre aluno e a escola, reduzindo a necessidade de encontros no espaço físico da instituição (Sanchez, 2007);

- Maximiza as experiências de aprendizagem ao passo que usuários promovem habilidades, provam novas ideias e aprendem com os erros;

Bennett \& Peachey (2007) observam mais um ponto relevante:

"O uso do Second Life no ensino de línguas permite aos estudantes maior controle sobre sua aprendizagem, empoderando-os (...). Facilitam atividades colaborativas e pró-ativas dentro de uma flexibilidade de tempo que ajuda os estudantes a investigarem os problemas em ambiente interativo." (BENNETT \& PEACHEY, 2007)

Outros benefícios desses ambientes de interação virtual para a aprendizagem valem ser citados, como a criação de contextos realísticos e autênticos, as frequentes negociações sociais e a percepção do processo de construção de conhecimento. Kay \& Fitzgerald (2008) ainda sugerem algumas atividades interessantes que podem ser executadas por esses meios: exibições e apresentações, simulações e encenações teatrais, recriações e reinterpretações de fatos históricos, filmes de animação (machinima), buscas de tesouros e pesquisas diversas, imersões culturais e linguísticas, escrita criativa, etc.

Outros possíveis usos para o ensino em geral tem sido investigados, como em Conklin (2007), por exemplo. Como o uso dessas ferramentas de simulação virtual é ainda oneroso, pois elas exigem computadores de última geração e internet de altíssima velocidade, é possível que muitos professores ainda não consigam usá-las de forma completa, mas é imperioso que comecemos a olhar para elas como uma tendência natural das interações futuras, formais e informais. É provável que as instituições físicas em breve tenham também seus avatares virtuais para atender melhor seu público, modernizando suas comunicações e inovando seus projetos. 


\subsubsection{Ferramentas para a coordenação dos projetos, interação e publicação}

Logo que surgiram os sites e aplicativos de redes sociais os professores perceberam seu potencial para o ensino. Imensuráveis projetos de escrita e interação virtual eram conhecidos em redes hoje não mais existentes, como o Orkut e o Microsoft Messenger, e muitos ainda estão em curso ou porvir nas redes modernas, já que elas permitem maior proximidade entre professores e alunos e desejável celeridade comunicativa, facilitando um melhor acompanhamento do andamento das tarefas, prontidão dos feedbacks e, consequentemente, a execução de projetos mais consistentes. Atualmente já é possível dizer que são raros os professores que, tendo acesso a tais ferramentas, não percebem ou aproveitam de suas facilidades para desonerar as interações a distância e aperfeiçoar as instruções didáticas, bem como o gerenciamento de atividades diversas.

Definidas como serviços baseados na web para prover a Comunicação Mediada por Computador (CMC) e que permitem aos indivíduos desde a construção de um perfil em um sistema interligado até compartilhar recursos com outros usuários a que estejam conectados (BOYD \& ELLISON, 2007), as redes sociais normalmente são suficientes para a coordenação dos projetos audiovisuais, pois através das telecomunicações entre os membros de um projeto é possível responder a todas as demandas instrucionais e eventuais que possam emergir junto a suas atividades.

Cada rede possui suas funcionalidades, alcance e possibilidades didático-pedagógicas e desde as mais comuns, como Facebook, Twitter, Google+, etc., às mais desconhecidas no mundo ocidental, como QZone e Sina Weibo, por exemplo, estão se multiplicando e aumentando exponencialmente o número de usuários. Entre os mais jovens sua presença é praticamente unânime e há também alguns aplicativos de conversas instantâneas que funcionam como redes sociais, como Whatsapp, Telegram, WeChat, Hangouts, Skype, etc.

Entretanto, atualmente existem ferramentas próprias para a coordenação de cursos à distância ou especiais para a comunicação entre alunos e professores. Bubbl.us, Brainify, Dropbox, QuizSnack, Astrid, Edmodo, Blackboard, Screen Chomp, Quizlet, GoClass e My Big Campus são alguns exemplos e algumas ferramentas já citadas também servem para tanto. Também vale citar sites e aplicativos que contemplam recursos de coordenação ou comunicação à distância: The Learning Manager, Conductor, LearnerWeb, Blogger, Manila, Free Open Diary, Perception, Quiz Rocket, Test Generator, Acid Pro, Peak e Sonar. Entre elas o Edmodo e o Blackboard têm amplo uso e aceitação no lócus de pesquisa, conforme 
evidenciado nas falas de alguns informantes em um grupo focal realizado e gravado no dia 26 de fevereiro de 2016 no CILC e apresentadas a seguir em forma de diálogos, pois o trecho escolhido resume a fala de múltiplos professores, porém sem identificá-los:

\footnotetext{
- "Para cada turma tenho uma sala virtual no Edmodo. Lá eu disponibilizo os testes, disponibilizo todas as atividades, listening, writing(...) Tudo a gente pode fazer no edmodo."

- "Também o que é legal é que lá tem o seu diálogo (com os alunos). Se eles fazem a atividade o professor verifica. Eles têm acesso à nota que eles tiraram e você pode modificá-la (...). Pode aplicar provas, a gente pode trabalhar vídeos, enfim tudo”.

- "É como se fosse um facebook. É moodle-facebook."

- "Ele reúne o moodle com o facebook. Igual ao Blackboard".

- "Ele não tem todos os recursos que o moodle, mas têm características semelhantes ao facebook que eles (os alunos) gostam. Tem interface agradável, parecendo o facebook".

- "Agora, o que eu acho legal também é que eles disponibilizam para o professor as comunidades que você tem interesse (...). Por exemplo, se você tem interesse em tecnologia então os professores que estão naquela área disponibilizam sites, aplicativos, tudo em relação aquele tema que você tem interesse e você pode explorar mais ainda através do edmodo.

- "Ele é muito intuitivo. Não tem muito segredo. Você pode mandar uma mensagem pra eles e eles respondem prontamente".

- "Mas eu acho que é assim, quando eu vou usar uma ferramenta nova, como o edmodo, eu chego e falo assim: "gente, é a primeira vez que eu vou usar, quando eu não souber vocês me ajudam e quando eu souber eu ajudo vocês". Eles percebem coisas que a gente não percebe. Eu ficava lá procurando aluno por aluno pra fazer o diário e a menina falou assim: "não professora, coloca aqui na busca o nome do aluno". Dá certo sim. O medo que a gente tem é mais de não falar pra eles "olha eu não sei ainda", mas quando você fala: "eu estou começando agora, vamos tentar, (fazer) uma experiência", eles ajudam você e naquela turma você cria experiência e quando é na próxima turma você já indica pra um colega porque é uma coisa que você já sabe mais e vai passando o conhecimento pros outros colegas.

- A tecnologia é uma coisa que nunca da pra você dizer que sabe tudo, pois tem um monte de coisas que eu não conhecia, que nunca tinha ouvido falar. Cada coisinha que você vai aprendendo vai ajudando mais a mudar dentro dessa nova realidade".
}

Percebe-se claramente que os professores dos CIL anseiam pela inclusão tecnológica como forma de aperfeiçoar as práticas, mas que também sentem necessidade de mais aprofundamento teórico e prático para poderem usá-la com mais segurança. Isso nos faz refletir sobre a importância de haver maior comunicação e intercolaboração entre o meio acadêmico, onde estão registradas diversas propostas e estudos sobre o ensino modernos e suas possibilidades tecnológicas, e o meio escolar, onde as práticas e interações funcionam como um laboratório natural de experimentação didático-pedagógica. Na área de linguística aplicada percebe-se também que há uma crescente demanda por pesquisas que abordem o poder das tecnologias digitais para dinamizar os cursos e responder às necessidades mutantes do mundo moderno, bem como prover aos alunos com amostras legítimas da língua em uso e oportunidades de prática comunicativa autêntica. 
Uma vez que todo projeto tem seu público alvo específico e potencial, para a publicação dos materiais produzidos há também populares sites de compartilhamento de material audiovisual que permitem a divulgação de vídeos e até mesmo o lucro com suas exibições. Entre os principais estão: Youtube, Dailymotion, Twitch, Liveleak, VEOH, Break, Metacafe, Vine, Flickr, Ustream, Facebook, Instagram e CollegeHumor. Esses sites ajudam a dar visibilidade aos produtos audiovisuais e a criar uma rede colaborativa, onde os produtores podem inspirar-se e inspirar os demais projetos, criando um ciclo virtuoso de práticas em direção ao desenvolvimento de habilidades e competências. Dawson \& Stein (2011, p. 9) também exaltam a importância da criação desse ciclo no ensino:

\begin{abstract}
"Nós vemos a aprendizagem como um tipo de ciclo virtuoso, um repetido processo de ação dirigida por um objetivo, a qual é ciclicamente aperfeiçoada através do processamento do feedback do ambiente. O aprendizado é um processo criativo, construtivo, de tentativa e erro, que é profundamente biológico. Amplamente falando, essa visão pode ser colocada sob o emblema do construtivismo, uma das mais coerentes e compreensivas famílias de teorias da aprendizagem (BALDWIN, [1906] 1975; PIAGET 1970). Teóricos recentes nessa tradição têm ampliado o horizonte de pesquisa do construtivismo para a neurociência, ciência da computação, a área da mente, cérebro e educação (FISHER, 2009; MARESCHAL, ET AL., 2007). O ciclo virtuoso da aprendizagem é amplamente aplicável, caracterizando modelos de redes neurais (SPITZER, 1999), aquisição linguística (TOMASELLO, 2005) e mesmo teoria política e governança (BUCK \& VILLINES, 2007). Acreditamos que o natural e em bom funcionamento do ciclo virtuoso de aprendizagem é um simples, porém poderoso, modelo que vale a pena ser inserido em novas tecnologias educacionais".
\end{abstract}

A criação desse ciclo nas escolas passa não somente pela mudança de estratégias e posturas de professores e alunos, mas também pela construção de um ambiente mais favorável à experimentação e, substancialmente, ao uso consciente das mais modernas ferramentas digitais disponíveis, capazes de promover uma livre absorção de insumo linguísticoinformativo. Uma escola que não tenta ampliar seu papel na vida e formação de seus alunos, assim como na sociedade em geral, corre o risco de perder com o passar dos anos sua relevância utilitária e seu poder de responder às demandas didático-pedagógicas emergentes em uma sociedade. Por isso, podemos ver a absorção das tecnologias modernas de informação e comunicação pelo ensino de línguas como um caminho sem volta, pois é comum uma nova ferramenta ou aparelho ganhar publicidade inicialmente como uma opção potencial e em seguida tornar-se indispensável, devido às mudanças nas formas de interação social que ela provocou. Assim ocorreu com os smartphones e alguns de seus aplicativos, por exemplo. 


\section{CONSIDERAÇÕES FINAIS}

Ante a resistências e inquietações percebidas nos CIL em relação ao uso de Ferramentas Digitais (FD) no Ensino de Língua Estrangeira (ELE), motivadas principalmente pelo desconhecimento por uma parte dos professores sobre as vantagens didáticas que tais ferramentas podem oferecer, este trabalho buscou reunir:

a) alguns princípios básicos sobre competência comunicativa (CC), considerando que o discernimento deste conceito reflete na construção e no aperfeiçoamento das estratégias didáticas relacionadas ao ELE;

b) alguns construtos teóricos sobre aquisição de língua estrangeira (ALE), por inferir que o conhecimento sobre este tema provoca um amadurecimento teórico necessário ao bom exercício profissional e por visar uma identificação de possíveis suportes ao uso Atividades de Produção Audiovisual (APA) como proposta didática;

c) algumas FD e suas potencialidades para viabilizar as APA propostas, estimular a autonomia na aprendizagem e auxiliar na coordenação dos cursos, pois constatamos que os professores em geral ainda conhecem pouco as tecnologias disponíveis que apresentam promissoras possibilidades de uso nos cursos.

Em meio às inúmeras possibilidades de uso de FD para apoiar atividades de prática linguística, optamos por apresentar e discorrer sobre as potencialidades e utilidades das APA e sobre as FD que as apoiam dividindo-as em duas categorias principais:

- Atividades e Ferramentas de Apoio à Produção Oral: representadas pelas que apresentam como produto final textos audiovisuais (palestras, filmes, canções, documentários, teatro, dança, TV, rádio, etc.).

- Atividades e Ferramentas de Apoio à Produção Escrita: representadas pelas que apresentam como produto final um texto escrito (livros, jornais, revistas, charges, histórias em quadrinhos, artigos, ensaios, blogs, etc.), impressos ou não.

Em meio a cada uma destas atividades foi possível indicar ferramentas como aplicativos, blogs, sites e programas capazes de dinamizar e facilitar cada produção proposta e tecer algumas reflexões sobre seus usos possíveis e ideais. 
Além disso, este estudo se propôs a investigar no lócus de pesquisa (CILT e CILC) como os professores têm utilizado as FD para promoverem APA que possam oportunizar a seus alunos práticas comunicativas em níveis mais elevados quanto a aspectos criativos e interacionais e, assim, aperfeiçoar seus cursos. Tal estratégia visou conhecer melhor os projetos em andamento para poder dialogar melhor com eles e, assim, incentivar o uso de algumas APA como modo de promover maior contato entre alunos e a língua alvo nos CIL e no ELE em geral.

A partir de uma perspectiva integradora que possibilitou encontrar em cada construto teórico suportes à produção audiovisual como estratégia ímpar para a ALE, ele é apresentado de modo a estimular reflexões sobre como algumas propostas didáticas e exemplos exitosos de uso de FD podem auxiliar os estudantes a desenvolverem maior CC em contextos de relativo isolamento linguístico-geográfico, como é o caso do Brasil. Percebemos que este país possui algumas características desfavoráveis à ampla prática de LE que podem ser superadas por APA e pelo uso consciente de algumas FD, pois elas ajudam na criação de eventos comunicativos capazes de estimular o uso autêntico e criativo do idioma em estudo.

Há uma pertinente demanda no ELE pela ampliação do uso de FD de forma simbiótica com os modos artísticos de comunicação (teatro, cinema, música, dança, etc.) para que ele possa acompanhar as transformações do mundo moderno. Em outras palavras, pode-se dizer que o ensino de LE clama por maior presença destas ferramentas e dos modos modernos de comunicação em suas estratégias didáticas para responder às necessidades contemporâneas dos alunos.

Para tanto, fazem-se necessários também estudos que visem conhecer melhor as potencialidades de cada ferramenta e nortear os demais docentes pela proposição e registro de atividades bem sucedidas e que merecem reverberação. Talvez seja ainda mais eficiente se as Instituições Educacionais puderem investir mais em pesquisas que abordem as vantagens e particularidades do uso de tecnologias de informação e comunicação no ensino, pois, diante das mudanças vigentes, o ensino de línguas parece atuar ainda como telespectador passivo, insciente de que as FD e as habilidades artístico-comunicativas estão cada vez mais se popularizando e se desmistificando.

É inegável que APA em geral podem contribuir para o ensino de línguas, pois ainda que criem alguns contextos simulados elas são amplamente ricas em processos que estimulam a prática comunicativa criativa e autêntica. Quanto às atividades e FD apresentadas por este trabalho, concluímos que são capazes de complementar os cursos de forma significativa, seja 
pela criação de simulações de uso real da LE ou pela criação de um ambiente estimulante de prática comunicativa. Elas ajudam também a retirar dos ombros dos professores um pouco da vigente carga de responsabilidade exclusiva pelo êxito ou insucesso do aluno, visto que a sala de aula precisa das extensões (atividades extraclasse) para superar suas limitações e enriquecer-se.

Dessa forma, vemos como imperiosa a necessidade dos cursos de línguas se fazerem presentes onde houver comunicação, pois é imprescindível que eles absorvam as habilidades e tecnologias que exercem a comunicação em uma sociedade, como são o rádio, a TV, o cinema, o teatro, a música, as atividades artísticas, etc. Cada atividade é rica em propostas comunicativas e informacionais capazes de oportunizar aos aprendizes relevantes experiências de uso criativo da língua, estimulando o desenvolvimento de seres mais reflexivos e fluentes, tanto na língua materna quanto na língua estrangeira.

Devido a essas razões facilitadoras e ao contexto multifacetado que as tecnologias de comunicação e informação representam, observamos que a educação em geral não poderá dar as costas às novas possibilidades interacionais e comunicativas que elas proporcionam, pois suas faces utilitárias são inúmeras ao ponto de fazê-las imprescindíveis nas mais diversas áreas de produção e conhecimento. Negligenciar o fato de que o mundo está em constante transformação e de que a educação precisa acompanhá-la para absorver as tecnologias contemporâneas e dominá-las cada vez mais, ao invés de ser dominada por elas, é tão absurdo quanto abandonar toda a construção epistemológica da pedagogia no século passado, por exemplo, conforme se observa em algumas linhas de pensamento que vêm ganhando espaço na sociedade brasileira.

Portanto, o caminho que nos parece mais louvável é de adequação das reconhecidas abordagens tradicionais às possibilidades e necessidades modernas. É imprescindível que haja uma dupla abordagem em que as verdades didáticas tradicionais apoiem as novas propostas para que ambas se aperfeiçoem, assim como os alunos se desenvolvem pela colaboração e intercambio de experiências em processos produtivos. Isto não nos levará à resolução de todos os problemas intrínsecos ao ELE, mas pode ser uma laudável resposta aos anseios modernos por atitudes mais efetivas diante das necessidades comunicacionais deste mundo cada vez mais globalizado que, já há algum tempo, vem se erguendo perante nossas ideologias, visões de mundo e valores educacionais.

Ainda, considerando a forma exponencial e imprevisível pelas quais as novas tecnologias vêm evoluindo e definindo os modos de comunicação, é inevitável perceber que o ensino de LE deve acompanhá-las lado a lado, pois o ensino, assim como a razão de ser dos 
modos modernos de comunicação, é antes de tudo inclusão, promovida por seus mestres e gestores ora através do empoderamento dos participantes ao absorverem conhecimentos e habilidades, ora pelo modo em que se dá a interação entre eles e o mundo atual.

No caso dos CIL é perceptível que, além de se conservarem às suas funções tradicionais, eles podem obter expressivos ganhos político-pedagógicos se passarem a funcionar também como rádios comunitárias, produtoras cinematográficas, ateliês artísticos, teatros, emissoras de televisão, editoras de livros e audiolivros, estúdio musical, salão de festas temáticas, etc. (ainda que em nível amador). Em outras palavras, a escola de línguas pode ser um ambiente propício para a execução dos mais diversos projetos didáticos, multidisciplinares e interdisciplinares, promovendo interação nos diversos modos de comunicação existentes e permitindo que os alunos encontrem onde praticar o que têm aprendido em sala.

Esperamos que esta pesquisa possa contribuir para que os professores reflitam sobre uma ou mais possibilidades didáticas e avaliem quais delas se adéquam mais a seu contexto de ensino para que - a partir de escolhas criteriosas quanto às APA, FD e suas vantagens possam aventurar-se em seu uso e aprofundar-se no conhecimento de seus processos e utilidades pedagógicas.

Entretanto, não foi possível observar o uso de todas as FD, principalmente no lócus de pesquisa, pois os professores ainda desconhecem sua extensão de possibilidades e usos vigentes no Brasil. As atividades que pudemos observar com maior profundidade, assim como os registros obtidos em maior quantidade, ganharam naturalmente, maior destaque neste trabalho. Reconhecemos que a opção pela compilação de muitas atividades e ferramentas nesta pesquisa não possibilitou descrições mais aprofundadas sobre cada estratégia de produção audiovisual, o que pode figurá-la como insuficiente para os leitores interessados em conhecer melhor apenas uma de suas propostas, mas acreditamos que foi possível a criação de um texto capaz de inspirar os professores a empreenderem projetos de produção criativa a partir das FD aqui indicadas.

Reconhecemos ainda a necessidade de realizar pesquisas mais específicas que possam, a partir da focalização mais estreita em uma ou mais atividades, evidenciar melhor seus processos, valores e utilidades para o ensino de línguas em geral. Por conseguinte, sugerimos que temas posteriores de pesquisa nessa área possam investigar de forma mais aprofundada as peculiaridades e qualidades de cada proposta didática, fornecendo maiores 
detalhes sobre o modo mais eficaz de uso de cada ferramenta, principalmente aos mais ineptos a respeito de seus usos e possibilidades.

Conforme já havíamos nos comprometido junto às escolas e professores pesquisados, pretendemos disponibilizar esta disssertação em suas bibliotecas. Acreditamos também que este trabalho possa ser útil para as demais escolas da rede de ensino que tenham línguas estrangeiras em suas grades curriculares e pretendemos disponibilizá-lo para consulta livre. Como o ensino de línguas em geral apresenta características regionais e universais, confiamos que esta pesquisa possa auxiliar os docentes das demais escolas de idiomas, desde que sejam adaptadas as considerações e propostas deste trabalho aos contextos e necessidades próprias dessas escolas e sua região social.

Ante a esses objetivos, as atividades propostas por este trabalho mostram-se proeminentes em relação à sua capacidade de gerar novas rotinas escolares capazes de criar incitamentos e estímulos à produção audiovisual como proposta didática relevante para o ELE. Assim sendo, observamos que um dos grandes desafios deste tipo de ensino no Brasil é propiciar aos aprendizes maiores níveis de experimentação do código linguístico para que, envolvidos em projetos de produção comunicativa, possam desenvolver suas habilidades de manipulação textual, pictórica e sinestésica com vistas a atingir elevados níveis de competência comunicativa e fluência linguística.

Seu tema é considerado muito pertinente e temos certeza de que futuras pesquisas poderão dialogar com os construtos deste trabalho, evidenciando mais possibilidades e vantagens do uso de FD no ensino de línguas em geral e confirmando as premissas quanto à importância de criar um ambiente escolar mais produtivo e criativo, estimulando a aprendizagem através de experiências de produção audiovisual. Vale ressaltar que, como o processo criativo é de maior interesse para o ensino do que seu produto final, o desenvolvimento da competência comunicativa está diretamente ligado à oportunização ao aprendiz de expressar-se através dos mais diversos modos de comunicação contemporâneos. Dessa forma, este trabalho foi proposto de modo a complementar algumas propostas já vigentes nas escolas, pois a necessidade de produção textual para o desenvolvimento pessoal e as atividades relacioandas ao desenvolvimento das habilidades de expressão são observadas em todo o ensino, pois são frequentes nas estratégias docentes volumosos estímulos à produção criativa. 



\section{REFERÊNCIAS}

ADELMAN, C. Kurt Lewin and the origins of action research. Educational Action Research, [S.1.], v. 1, n. 1, 1993, p. 7-24. Disponível em: <http://www.tandfonline.com/ doi/pdf/10.1080/0965079930010102>. Acesso em 21 abr. 2015.

ALMEIDA FILHO, J. C.; BARBIRATO, R. C. Interação e aquisição na aula de língua estrangeira. Campinas, EdUFSCAR. 2016.

ALMEIDA, Virgilio Pereira de. Conhecendo as regras do jogo: a competência comunicativa e os manuais didáticos de ensino de inglês como língua estrangeira. 2011. 263 f. Tese (Doutorado em Linguística)-Universidade de Brasília, Brasília, 2011.

ALVAREZ, Maria Esmeralda Ballestero. Organização, sistemas e métodos. São Paulo: McGraw Hill, 1991. 2 v.

ANZALONE, Stephen; BOSCH, Andrea. Improving educational quality through interactive radio instruction: a toolkit for policy makers and planners [S.l.]: The World Bank, 2005. (African region human development working paper series, 52). Disponível em: <http://siteresources.worldbank.org/EXTAFRREGTOPDISEDU/Resources/WBIRItoolkit_05 .pdf>. Acesso em: 06 maio 2016.

AUSUBEL, D. Educational psychology: a cognitive view. 2. ed. New York: University of Michigan, 1978. Disponível em: 〈http://www.theoryfundamentals.com/ausubel.htm>. Acesso em: 28 jun. 2016.

AUSUBEL, D.P. The psychology of meaningful verbal learning. New York: Grune and Stratton, 1963.

BAKHTIN, M. Problems of Dostoevsky's poetics. Edited and translated by Caryl Emerson. Manchester: University of Manchester Press, 1984. (Theory and history of literature, v. 8).

BARROZO. F. H. Especificidades avaliativas a serem observadas no Ensino de Língua Estrangeira Moderna. Brasília: Universidade de Brasília, 2016 Distrito Federal. 2016. Disponível em: 〈https://1drv.ms/b/s!AgvN1kn1alqVim91Tf-kgH0BI0Rt〉. Acesso em: 26 set. 2016.

BARROZO. F. H. Por uma maior presença dos meios modernos de comunicação e suas tecnologias no Ensino de Língua Estrangeira (ELE). Brasília: Universidade de Brasília, 2015. Disponível em: 〈https://1drv.ms/b/s!AgvN1kn1alqVimX4YAeRrZzX3sue〉. Acesso em: 16 set. 2016.

BATES, D. Wordgames: activities for creative thinking and writing. London: Longman, 1993. Disponível em: <http://education.maritime.history.sa.gov.au/documents/Poetry Wordgames.pdf $>$. Acesso em 11 abr. 2016.

BEERS, K. Listen while you read. School Library Journal, [S.1.], apr. 1998. Disponível em: <https://www.tales2go.com/wp-content/uploads/2015/08/Listen-While-You-Read.pdf $>$.

Acesso em 15 abr. 2016. 
BENNETT, Jacquie; PEACHEY, Anna. Mashing the MUVE: A mashup model for collaborative learning in multi-user virtual environments. In: CONFERENCE ICL, 2007, Villach, Austria. Anais eletrônicos... Villach: Kassel University Press, 2007. 18 p.

BOGDAN, R. C.; BIKLEN, S. K. Qualitative research for education: an introduction to theory and methods. Needham Heights, MA: Allyn \& Bacon, 1991.

BORG, S.; AL-BUSAIDI, S. Teachers' beliefs and practices regarding learner autonomy. ELT Journal, Oxford, v. 66, n. 3, p. 283-292, 2012.

BOYD, D.; ELLISON, N. Social network sites: definition, history, and scholarship. Journal of Computer-Mediated Communication, Pennsylvania, v. 13, n. 1, p. 210-230, 2008. Disponível em: <http://onlinelibrary.wiley.com/doi/10.1111/j.1083-6101.2007.00393.x/pdf>. Acesso em: 25 maio 2016.

BRAGA, D. Tecnologia da informação e comunicação e novos letramentos. In:

(Org.). Tecnologias digitais da informação e comunicação e participação social. São Paulo: Cortez, 2013. p. 39-46.

BRASIL. Ministério da Educação. Secretaria da Educação Média e Tecnológica. Parâmetros Curriculares Nacionais +: PCN+. Brasília: MEC, 2002.

BROWN, D. S. Secondary teacher's participation in action research. The High School Journal, v. 75, n. 1, p. 48-58, out./nov. 1991.

BROWN, H. D. Principles of language learning and teaching. 5. ed., New York: Longman, 2007.

BROWN, H. D. Teaching by principles: an interactive approach to language pedagogy. Englewood Cliffs, New Jersey: Prentice Hall Regents. 1994.

BUTLER-PASCOE, M. E.; WIBURG, K. M. Technology and teaching english language learners. Boston: Allyn and Bacon, 2003.

CAMPBELL, D. T.; FISKE, D. W. Convergent and discriminant validation by the multitraitmultimethod matrix. Psychological Bulletin, Washington, v. 56, n. 2, p. 81-105, 1959.

CANALE, M. From communicative competence to communicative language pedagogy. In: J. RICHARDS; R. SCHMIDT (Org.). Language and communication. London: Longman. 1983

CANALE, Michael; SWAIN, Merrill. Theoretical bases of communicative approaches to second language teaching and testing. In: Applied linguistics. Oxford University Press. 1980.

CARMEN ARANDA, M. Interações orais online no ensino do francês língua estrangeira: o projeto Cefradis. 2001. 226 f. Tese (Doutorado em Letras)-Universidade de São Paulo, 2001. 
CASSELL, J.; WAX, M. Ethical problems in fieldwork. Social Problems, v. 27, n. 3, p. 259264, fev. 1980.

CASSELL, J. A. Field manual for studyillg desegregated schools. Washington, DC: The National Institute of Education, 1978. In: BOGDAN, C. R.; BIKLEN, S. K. Investigação qualitativa em ação: uma introdução à teoria e as métodos. Portugal: Porto Editora, 1994.

CCT - CENTER FOR CHILDREN AND TECNOLOGY. Television goes to school: the impact of video on student learning in formal education. Washington, DC: Corporation for Public Broadcasting, 2004. Disponível em: <https://www.dcmp.org/caai/nadh173.pdf>. Acesso em: 09 maio 2016.

CELANI, M. A. Afinal, O que é linguística aplicada? In PASCHOAL, M.S.Z.; CELANI, M.A. (Org.). Linguística aplicada: da aplicação da linguística à transdisciplinaridade. São Paulo: Edu, 1992.

CENOZ IRAGUI, Jasone. El concepto de "Competencia Comunicativa" en Vademécum para la formación de profesores. In: extranjera. Madrid: SGEL, 2004. p. 449- 465. Enseñar español como segunda lengua/ lengua

COÊLHO, M. As oficinas de teatro no processo ensino aprendizagem e na formação dos professores de língua inglesa - um estudo "Q". 136 f. 2010. Dissertação (Mestrado em Linguística)-Universidade Federal de Uberlândia, Uberlândia, 2010.

CONKLIN, Megan S. 101 uses for second life in the college classroom. San Francisco: Elon University, 2007. Disponível em: 〈http://uksl.pbworks.com/f/101Uses4SecondLife.pdf> Aesso em: 23 maio 2016.

COOK, C. H. The play way: an essay in educational method. London: Heinemann, 1971.

COSCARELLI, C. V. O Uso da informática como instrumento de ensino-aprendizagem. Presença Pedagógica, Belo Horizonte, v. 4, n. 20, mar./abr. 1998, p.52.

COSTA, G.S. Breve histórico da linguística aplicada. [S.1.], 2001. Texto disponível na página pessoal on-line da autora. Disponível em: <http://www.giseldacosta.com/wordpress/ wp-content/uploads/2015/04/2184332-Breve-historico-da-linguistica-aplicada.pdf $>$. Acesso em: 05 out. 2016.

DAMASCO, Denise G. Contando uma história: o ensino público de línguas estrangeiras a partir das interpretações de jovens e de docentes do Distrito Federal. 463 f. 2014. Tese (Doutorado em Educação)-Univesidade de Brasilia, Faculdade de Educação, 2014. p. 164170 .

DAMASCO, Denise G. Uma proposta de periodização do ensino de línguas estrangeiras no distrito federal: 1959-2012. Revista HELB, Brasília, n. 6, 2012. Disponível em: <http://www.helb.org.br/index.php?option=com_content\&view=category\&layout=blog\&id=1

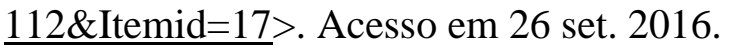


DAWSON, L.; STEIN, Z. Virtuous cycles of learning: redesigning testing during digital revolution. Northampton, MA: Lectica, 2011. Disponível em: <https://dts.lectica.org/PDF/2012_0929_virtuous_cycles.pdf >. Acesso em: 30 maio 2016.

DE BOT, K. Introduction: second language development as a dynamic process. Modern Language Journal, Hoboken, v. 92, n. 2, p. 166-178, 2008.

DESROCHE, H. Pesquisa-ação: dos projetos de autores aos projetos de atores e reciprocamente. In: THIOLLENT, M. (Org.). Pesquisa-ação e projeto cooperativo na perspectiva de Henri Desroche. São Carlos: EdUFSCAR, 2006.

DEVI, V. A. Using animation for teaching phrasal verbs: A brief indian experiment. Language In India, Bloomington, v. 5, n. 8. 2005. Disponível em: <http://www.languageinindia.com/aug2005/ animationanitha1.html $>$. Acesso em: 30 maio 2016.

EINSTEIN, Albert. A Teoria da Relatividade Especial e Geral. São Paulo: Atlas,1991.

EL ANDALOUSSI, K. Pesquisas-ações: ciências, desenvolvimento, democracia. São Carlos, SP: EdUSCar, 2004.

ELLIS, R. Modified oral input and the acquisition of word meanings. Applied Linguistics, Oxorfd, v.16, n. 4, p. 409-441, 1995. Disponível em: <10.1093/applin/16.4.409>. Acesso em: 06 out. 2016.

FERGUSON, Charles A. Diglossia. Word, n. 15, p. 325-340, 1959. Disponível em: <http://pt.scribd.com/doc/46164668/2-Diglossia\#scribd;http://en.wikipedia.org/wiki/Charles A. Ferguson>. Acesso em: 22 jun. 2015.

FETTERMAN, D. M. Ethnography: step by step. London: Sage, 1998.

FLOWER, L.; HAYES, J. R. A cognitive process theory of writing. College Composition and Communication, v. 32, n. 4, p. 365-387, dez. 1981.

FLOWER, L. Cognition, context, and theory building. College Composition and Communication, v. 40, n. 3, p. 282-311, out. 1989.

FRANCO, M. A. S. Pedagogia da Pesquisa-Ação. Educação e Pesquisa, São Paulo, v. 31, n. 3, p. 483-502, set./dez. 2005.

FREIRE, Paulo. Pedagogia do oprimido. Rio de Janeiro: Paz e terra, 1970.

FREIRE, Paulo. Pedagogia da esperança: um reencontro com a pedagogia do oprimido. Rio de Janeiro: Paz e Terra, 1992.

FROSINI, T. Access to Internet as a Fundamental Right. Italian Journal of Public Law, Milano, v. 5, n. 2, p. 230, 2013. Disponível em: <http://www.ijpl.eu/assets/files/pdf/2013 volume_2/7.Frosini.pdf >. Acesso em: 03 jun. 2016. 
GORDEN, R. L. Interviewing strategy, techniques, and tactics. Homewood: Dorsey, 1980.

HAGUETTE, T. M. F. Metodologias qualitativas na sociologia. 3. ed. Petrópolis: Vozes, 1992.

HARPER, D. On the authority of the image: visual methods at the crossroads. In: DENZIN, Norman K.; LINCOLN, Yvonna S. (Org.). Handbook of qualitative research. Thousand Oaks, Sage Publications, 1994. p. 403-412.

HATCH, E. M.; LONG, M. H. Discourse analysis, what's that? ln: LARSEN-FREEMAN, D. Discourse analysis in second language research. Rowley: Newbury House, 1978. p. 1-40.

HEIGHAM, Juanita; SAKUI, Keiko. Ethnography. In: HEIGHAM, Juanita; CROKER, Robert A. Qualitative research in Applied Linguistics: a pratical introduction. Great Britain: Palgrave Macmilian, 2009.

HERNÁNDEZ, F. Cultura visual, mudança educativa e projeto de trabalho. Porto Alegre: Artmed, 2000.

HOLEC, H. Autonomy in foreign language learning. Oxford: Pergamon. 1981.

HOOD, Michael. Case Study. In: HEIGHAM, Juanita; CROKER, Robert A. Qualitative research in applied linguistics: a pratical introduction. Great Britain: Palgrave Macmilian, 2009.

HORGAN, J. A theory of almost everything. The New York Times, October 1, 1995. Artigo publicado no Book Review Section do jornal The New York Times. Disponível em: <http://www.nytimes.com/1995/10/01/books/a-theory-of-almost-everything.html? pagewanted=all $>$. Acesso em: 6 out. 2016.

HUNDSBERGER, S. (2009). Foreign language learning in second life and the implications for resource provision in academic libraries. Cambridge: Arcadia Project, 2009. Documento publicado no portal Arcadia, mantido pela University Library da University of Cambridge. Disponível em: 〈http://arcadiaproject.lib. cam.ac.uk/docs/second_life.pdf $>$. Acesso em: 20 maio 2016.

HYLAND, Ken. Second language writing. Cambridge, UK: Cambridge University Press, 2003.

HYMES, Dell H. On communicative competence. In PRIDE, J.B.; HOLMES, J. Sociolinguistics. England: Penguin Books, 1972.

JOHNSON, B. R. Examining the validity structure of qualitative research. Education, v. 118, n. 3, p. 282-292, nov.1997.

JOHNSON, S. D. Will our research hold up under scrutiny? Journal of Industrial Teacher Education, Blacksburg, v. 32, n. 3, p. 3-6. 1995.

JOHNSTONE, B. Qualitative methods in sociolinguistics. New York: Oxford University Press, 2000. 
KAY. J.; FITZGERALD, S. Educational uses of second life. [S.1.], 2008. Disponível em: <http://sleducation.wikispaces.com/educationaluses>. Acesso em: 24 maio 2016.

KAYMAS, S. Distance education broadcasting in developing and developed countries. Ankara, Turkey, 1999.

KRASHEN, S. Second language acquisition and second language learning. [S.1.], 1981. Disponível em: <http: // www.sdkrashen.com/ SL_Aquisition_and_Learning/ index.html>. Acesso em: 6 out. 2016.

KRASHEN, S. Principles and practice in second language acquisition. Oxford: Pergamon Press, 1982.

KRASHEN, S. The Input Hypothesis: issues and implications. 4. ed. New York: Longman. 1985.

KRESS, G. R.; VAN LEEUWEN, T. Reading images: a grammar of visual design. Londres: Routledge, 1996.

LARSEN-FREEMAN, D. Chaos/Complexity science and second language acquisition. Applied Linguistics, v. 18, n. 2, p. 141-165, 1997.

LEIGH, STUART; CASH, FRANCIS. Effectiveness and methodology of interactive radio instruction. In: DOCK, Alan; HELWIG, John (Eds.). Interactive radio instruction: impact, sustainability, and future directions. Washington, DC: World Bank, 1999. (Education and Technology Technical Notes, 4, Series 1).

LÉVY, Pierre. Cibercultura. 2. ed. São Paulo: Editora 34, 2000.

LEWIN, K. Field theory in social Science:selected theoretical papers. New York: Harper \& Row, 1951.

LITTLE, D. Learning as dialogue: the dependence of learner autonomy on teacher autonomy. System, Dublin, v. 23, n. 2, p. 175-182, 1995.

LITTLEWOOD, W. The task-based approach: some questions and suggestions. ELT Journal, v. 58, n. 4, p. 31-26, 2004.

LONG, M. H. Input, Interaction and second language acquisition. 1980. Tese (Doutorado)-University of California in Los Angeles, Los Angeles, 1980.

MACINTYRE. C. The art of action research in the classroom. London: David Fulton, 2002.

MANZATO, A. J.; BARBOSA SANTOS, A. A elaboração de questionários na pesquisa quantitativa. [São Paulo]: UNESP, 2012. Disponível em: $<$ http://www.inf.ufsc.br/ vera.carmo/Ensino_2012_1/ ELABORACAO_QUESTIONARIOS PESQUISA_QUANTITATIVA.pdf >. Acesso em 11 set. 2015 
MÁRCIO DA SILVA, A.; ROTTAVA, L. Blended learning no ensino de português língua estrangeira adicional: Tarefas assíncronas extra-classe. Portuguese Language Journal, v. 9, article 1, 2015.

MASTEN, A. S. Ordinary magic: resilience processes in development. American Psychologist Journal, v.56, n. 3, p. 227-238, mar. 2001.

MCFARLAND, K.P.; STANSELL, J.C. Historical perspectives. In: PATTERSON, L.; SANTA, C. M.; SHORT, C. G.; Short; SMITH, K. (Eds.). Teachers are researchers: feflection and action. Newark, DE: International Reading Association, 1993.

MESQUITA, Príscila Patrícia Paiva. (Re) Construindo políticas públicas para os Centros Interescolares de Línguas do Distrito Federal. 2013. 280 f. Dissertação (Mestrado em Linguística Aplicada)-Instituto de Letras, Departamento de Línguas Estrangeiras e Tradução, Universidade de Brasília, 2013. p. 53-90.

MOHANTY, S. Technology in language classrooms: filmmaking as a tool for improving life skills. In: INTERNATIONAL SYMPOSIUM CELC/ NUS, 3., 2011, Singapore. Selected Papers, Singapore, 2011.

MORGAN, D. L. Focus groups. Annual Review of Sociology, v. 22, n.1, p. 129-152, 1996.

MORIN, A. Pesquisa-ação integral e sistêmica: uma antropopedagogia renovada. Rio de Janeiro: DP\&A, 2004.

MURRAY, D. A writer teaches writing. 2. ed. Boston: Houghton Mifflin. 1985.

NOFFKE, S.E.; STEVENSON, R.B. (Eds.). Educational action research: Becoming practically critical. New York: Teachers College Press, 1995.

ODERA, F. Y. Learning Kiswahili language by radio at distance in secondary schools in Nyakach. Nyando District, Kenya, 2008.

PAIVA, Vera Lúcia Menezes de Oliveira e. Aquisição de Segunda Língua. São Paulo: Parábola Editorial, 2014.

PAIVA, Vera Lucia Menezes de Oliveira e. Caleidoscópio: fractais de uma oficina de ensino aprendizagem de língua inglesa. Belo Horizonte: Faculdade de Letras da UFMG, 2002. (Memorial para concurso de Professor Titular da UFMG).

PAIVIO, A. Imagery and verbal processes. New York: Holt, Rinehart, and Winston, 1971.

PAIVIO, A. Images in mind: the evolution of a theory. Sussex, U.K.: Harvester Wheatsheaf, 1991.

PAIVIO, A. Mental Representations: A dual coding approach. New York: Oxford University Press, 1986.

PAIVIO, A. Mind and its evolution: a dual coding theoretical approach. Mahwah, NJ: Erlbaum, 2007. 
PAIVIO, A.; BEGG, I. The psychology of language. Englewood Cliffs, NJ: Prentice-Hall, 1981.

PARAN, A. The stories of literature and language teaching. In A. Paran (Ed.), Literature in language teaching and learning. Alexandria, VA: TESOL. 2006. P. 1-10.

PATTON, M. Q. Qualitative evaluation and research methods. 3. ed. Thousand Oaks, CA: Sage Publications, 2002.

PEREIRA, Regina Celi; ROCA, Pilar. Linguística aplicada: um caminho com diferentes acessos. São Paulo: Contexto, 2009.

PUNCH, M. The politics and ethics of fieldwork. Newbury Park, CA: Sage, 1986.

Ribeiro, Washington. Alice no país das maravilhas tecnológicas: uma história sobre tecnologias digitais no ensino de línguas. UnB. Distrito Federal. 2014. p. 72.

ROSA, M. V. F. P. C.; ARNOLDI, M. A. G. C. A entrevista na pesquisa qualitativa. Belo Horizonte: Autêntica, 2006.

RUIZ, P. J. Art as a tool for teachers of English language learners. New York, The New York State Education Department Office of Bilingual Education and Foreign languages Studies/University of The State of New York, 2010. Disponível em: <http://www.p12.nysed.gov/ biling/docs/Art_as_a_Tool-for_Teachers.pdf $>$. Acesso em: 10 jun. 2016.

SADOSKI, M.; PAIVIO, A. Imagery and text: A dual coding theory of reading and writing. Mahwah, NJ: Erlbaum. 2001

SAGARRA, N.; ZAPATA, G. C. Blending classroom instruction with online homework: a study of student perceptions of computer-assisted L2 learning. ReCALL, v. 20, n. 2, p. 208$224,2008$.

SALT, B., ATKINS, C., BLACKALL, L. Engaging with second life: real education in a virtual world. [S.1.], 2008. Disponível em: <http://slenz.files.wordpress.com/2008/12/ slliteraturereviewa1.pdf $>$. Acesso em 19 maio 2016)

SANCHEZ, J. Second Life: an interactive qualitative analysis. In: Proceedings of Society for Information Technology and Teacher Education International Conference, Chesapeake, v. 2007, n. 1, 2007.

SANT'ANA, Juscelino da Silva. O Cisne e o patinho: esperança e retrocesso na história de um centro público de línguas. Revista HELB, v. 4, 2010. Disponível em: $<$ http://www.helb.org.br/index.php?option=com_content\&view=category\&layout=blog\&id=1

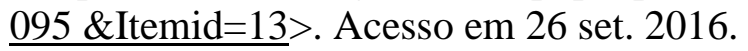

SEARLE, John R. Chomsky's revolution in linguistics, The New York Review of Books, june 29, 1972. 
SOUTO FRANCO, Marilda; LMEIDA FILHO, J. Carlos P. O conceito de competência comunicativa em retrospectiva e perspectiva. Revista Desempenho, n. 11, p. 04-22, jun. de 2009.

STOFFEL, A. et al. O aluno e seu (des)interesse pela escola. Porto Alegre: UFRGS, 2008. Disponível em: <http://www.ufrgs.br/psicoeduc/wiki/O_aluno_e_seu_(des)interesse_pela escola $>$. Acesso em: 28 jun. 2016.

STRAUSS, A. Qualitative analysis for social scientists. New York: Cambridge University Press, 1987.

Strauss, A.; Corbin, J. Basics of qualitative research: grounded theory procedures and techniques. Newbury Park, CA: Sage Publications, 1990.

SWAIN, M.; LAPKIN, S. Problems in output and the cognitive processes they generate: a step towards second language learning. Applied Linguistics, n. 16, 1995.

THEODOSAKIS, N. The director in the classroom: how filmmaking inspires learning. San Diego, CA: Tech4Learning, 2001.

TILSON, T. et al. Sustainability in Four Interactive Radio Projects: Bolivia, Honduras, Lesotho, and Papua New Guinea. In: LOCKHEED, M. E.; MIDDLETON, J.; NETTLETON, G. S. (Ed.). Educational technology: sustainable and effective use. Washington, D.C: Population and Human Resources Department/World Bank, 1991. (PHREE, 91/32).

WARBURTON, S. Second Life in higher education: assessing the potential for and the barriers to deploying virtual worlds in learning and teaching. British Journal of Educational Technology, v. 40, n. 3, p. 414-426, 2009.

WATTS, H. When teachers are researchers, teaching improves. Journal of Staff Development, v. 6, n. 2, p. 118-127, 1985.

YOUNG, D. An investigation of students' perspectives on anxiety and speaking. Foreign Language Annals, n. 23, 1990.

ZAMEL, V. The composing processes of advanced ESL students: six case studies. TESOL Quarterly, n. 17, p.165-87, 1983. 


\section{APÊNDICE I}

\section{DADOS DA PESQUISA}

OS ARQUIVOS E MATERIAIS DE MULTIMÍDIA REFERENTES ÀS ENTREVISTAS, QUESTIONÁRIOS, GRUPOS FOCAIS, TERMOS DE COMPROMISSO, AMOSTRAS DE TRABALHOS, ENTRE OUTROS NÃO ANEXADOS A ESTA DISSERTAÇÃO, ESTÃO DISPONÍVEIS PARA CONSULTA PÚBLICA NO ENDEREÇO VIRTUAL https://1drv.ms/f/s !AgvN1kn1alqVhBhoYhplw6ZQxrZ_ OU PELO QR CODE ABAIXO:

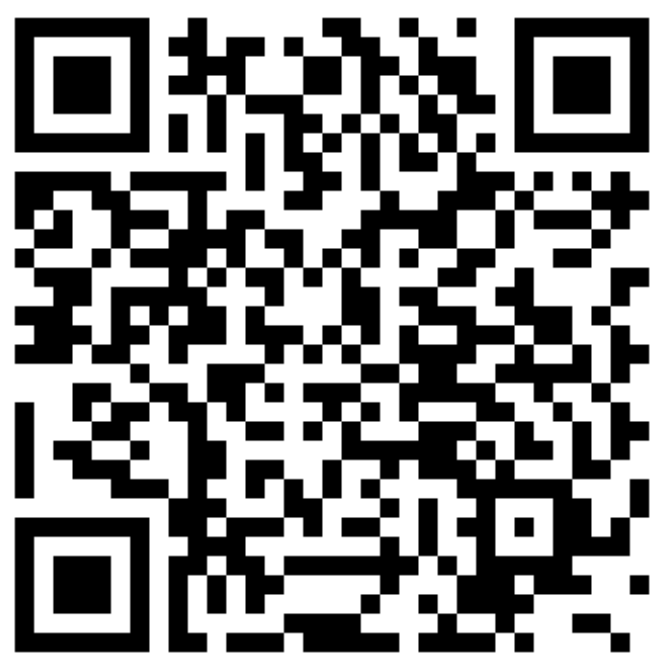

EM CASO DE DIFICULDADES PARA ACESSÁ-LOS ENVIE UMA SOLICITAÇÃO PARA OS ENDEREÇOS fabioh01@yahoo.com.br OU fabioh01@hotmail.com. 


\title{
APÊNDICE II
}

\section{Universidade de Brasília $50_{2012}^{1962}$}

\author{
Departamento de Línguas Estrangeiras e Tradução \\ Programa de Pós-Graduação em Estudos da Tradução \\ Pesquisador: Fábio Henrique Barrozo
}

Tema da Pesquisa: A Contribuição das Tecnologias de Comunicação e das Artes com o Ensino de Línguas

Descrição: essa pesquisa tem o objetivo de coletar informações junto aos professores de língua estrangeira moderna e, consequentemente, poder prover-lhes com ferramentas facilitadoras para seu trabalho e com o aprofundamento teórico necessário a uma consciência maior sobre a importância de adequar o ensino de línguas ao contexto dinâmico e interativo atual. Essa entrevista visa colher registros de sucesso com o uso de modernas tecnologias de comunicação ou atividades artísticas no ensino de línguas.

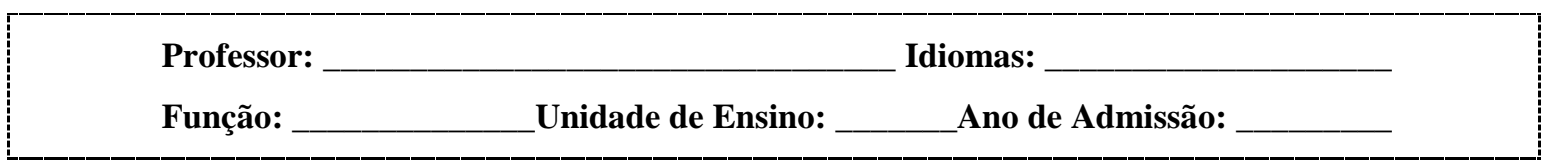

\section{Roteiro de Entrevista}

- Utilize os campos abaixo para apresentar sua opinião sobre os temas apresentados:

1) Quais projetos usando modernas tecnologias de comunicação ou atividades artísticas que você realizou que considera mais relevantes?

2) Descreva cada projeto segundo as seguintes questões:

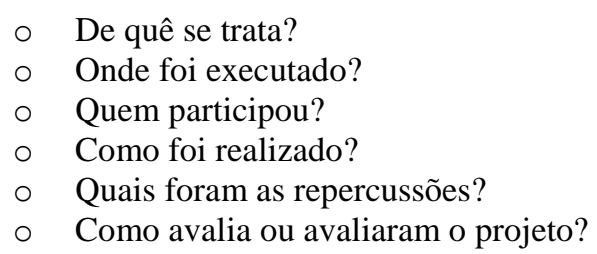

3) Indicaria outros projetos semelhantes?

Nome do professor executor: Unidade:

4) Como você vê a importância da absorção das modernas tecnologias de comunicação e atividades artísticas para promover maior contato dos alunos com a língua estrangeira?
○ (_) Indiferente
- (_) Pouco relevante
- (_) Muito Relevante
○ (_) Imprescindível

Justifique sua opinião

- Grato pela participação na pesquisa. Esses dados poderão ser usados para enfatizar a relevância das novas tecnologias de comunicação e atividades artísticas a partir do exemplo de êxito descrito pelo participante da pesquisa e para demais análises sobre o status do ensino e seu contexto contemporâneo.

$$
\text { Data: }
$$




\section{APÊNDICE III}

\section{Universidade de Brasília}

$50_{2012}^{1962}$

Departamento de Línguas Estrangeiras e Tradução

Programa de Pós-Graduação Linguística Aplicada

Pesquisador: Fábio Henrique Barrozo

Tema da Pesquisa: A Contribuição das Tecnologias de Comunicação e das Artes com o Ensino de Línguas Descrição: (idem ao questionário do Anexo I)

Professor: Função: Unidade de Ensino:

Idiomas: Ano de Admissão:

\section{QUESTIONARIO SOBRE AVALIAÇÃO}

- Utilize os campos abaixo para apresentar sua opinião sobre os temas apresentados:

1) Adotaria ferramentas online na avaliação de seus alunos? SIM (__ N N ÃO (_)

2) Conhece alguma ferramenta digital de avaliação (site, aplicativo, etc.)?

3) Tem alguma preferência pela Avaliação Processual (Formativa)? SIM (_) NÃO (__)

4) Quais habilidades seus testes escritos avaliam?

(__ Gramática (__ Leitura (__) Escrita (__ Compreensão Oral (__) Vocabulário

5) Os testes escritos correspondem a quanto por cento das menções finais na sua escola:

(_) $>70 \%$ (_ $)>50 \%$ (_ $)<50 \%$ (_) $<30 \%$

6) Quais estratégias são usadas para a avaliação da produção oral ou habilidade de comunicação?

(__) Entrevistas (_) Seminários (__) Encenações (__) Gravações (__) Outra:

7) Qual o principal desafio ou problema que você identifica na avaliação em sua escola?

(5 linhas)

8) Aproveite esse espaço caso queira apresentar sugestões, críticas ou demais comentários sobre as práticas atuais de avaliação na sua escola ou na rede:

Data: 


\section{APÊNDICE IV}

\section{$\Psi$ Universidade de Brasília $50_{2012}^{1902}$

\author{
Departamento de Línguas Estrangeiras e Tradução \\ Programa de Pós-Graduação em Linguística Aplicada \\ Pesquisador: Fábio Henrique Barrozo
}

\section{Termo de Consentimento}

Tema da Pesquisa: A Contribuição das Tecnologias de Comunicação e das Artes com o Ensino de Línguas

Descrição: esta pesquisa tem o objetivo de coletar informações junto aos professores de língua estrangeira moderna e, consequentemente, poder prover-lhes com ferramentas facilitadoras com seu trabalho e com o aprofundamento teórico necessário a uma consciência maior sobre a importância de adequar o ensino de línguas ao contexto dinâmico e interativo atual. Esse Termo de Consentimento visa dar maior tranquilidade aos pesquisados e aos pesquisadores à medida que assegura maior formalidade em relação aos aspectos deontológicos relacionados a uma pesquisa acadêmica.

Professor:
Função:

1) Natureza da pesquisa: Você foi convidado a participar da pesquisa descrita acima que será utilizada para em uma dissertação de mestrado no Programa de Pós-graduação em Linguística Aplicada da UnB.

2) Participantes da pesquisa: Professores dos Centros Interescolares de Línguas do Distrito Federal.

3) Participação na pesquisa: Sua participação é voluntária. Você tem a liberdade de recusar a participar ou ainda, em qualquer fase da pesquisa, pode se recusar a continuar participando, sem qualquer prejuízo.

4) O registro: Os dados serão utilizados na referida dissertação de mestrado, bem como poderão ser usados para fins de publicação científica, ensino e encontros científicos.

5) Confidencialidade: Todas as informações coletadas nesta pesquisa são estritamente confidenciais, de forma que a sua identidade será preservada. Os relatos da entrevista serão identificados por código ou nomes fictícios, salvo autorização de citação nominal expressa abaixo (marque $\mathrm{X}$ ):

(_) Autorizo a citação de meu nome na pesquisa (_) Não Autorizo a citação de meu nome na pesquisa

6) Benefícios: Ao participar desta pesquisa você estará contribuindo para o aperfeiçoamento das práticas de ensino em sua instituição e poderá usá-la como referencia para defender maior presença das ferramentas digitais no Ensino de LEM para promover maior contato dos alunos com a língua alvo por meio da produção audiovisual.

7) Pagamento: Você não terá nenhum tipo de despesa por participar desta pesquisa e nada será pago por sua participação. Sempre que quiser você poderá obter mais informações sobre a pesquisa. Poderá ainda entrar em contato com o coordenador da pesquisa através do e-mail janainasoares.unb@gmail.com.

Ciente dos termos acima assina o participante:

Em: 


\section{Universidade de Brasília}

Departamento de Línguas Estrangeiras e Tradução

Programa de Pós-Graduação em Estudos da Tradução

Pesquisador: Fábio Henrique Barrozo

Tema da Pesquisa: A Contribuição das Tecnologias Audiovisuais e das Artes com o Ensino de Língua Estrangeira Moderna

Descrição: essa pesquisa tem o objetivo de coletar informações junto aos professores de língua estrangeira moderna e, consequentemente, poder prover-lhes com ferramentas facilitadoras de seu trabalho e com o aprofundamento teórico necessário a uma consciência maior sobre a importância de adequar o ensino de línguas ao contexto dinâmico e interativo atual. Esse grupo focal visa conhecer melhor os desafios enfrentados e os principais problemas que têm dificultado a aquisição linguística nos CIL's, bem como a relevância do problema apresentado: o pouco contato dos estudantes com a língua alvo.

\section{REGISTRO DE DEBATE - GRUPO FOCAL}

Instituição de ensino: Cidade:

\begin{tabular}{|l|l|}
\hline Nome & Língua Ensinada \\
\hline & \\
\hline & \\
\hline & \\
\hline & \\
\hline & \\
\hline Data: $\_/$ \\
\hline
\end{tabular}




\section{APÊNDICE VI}

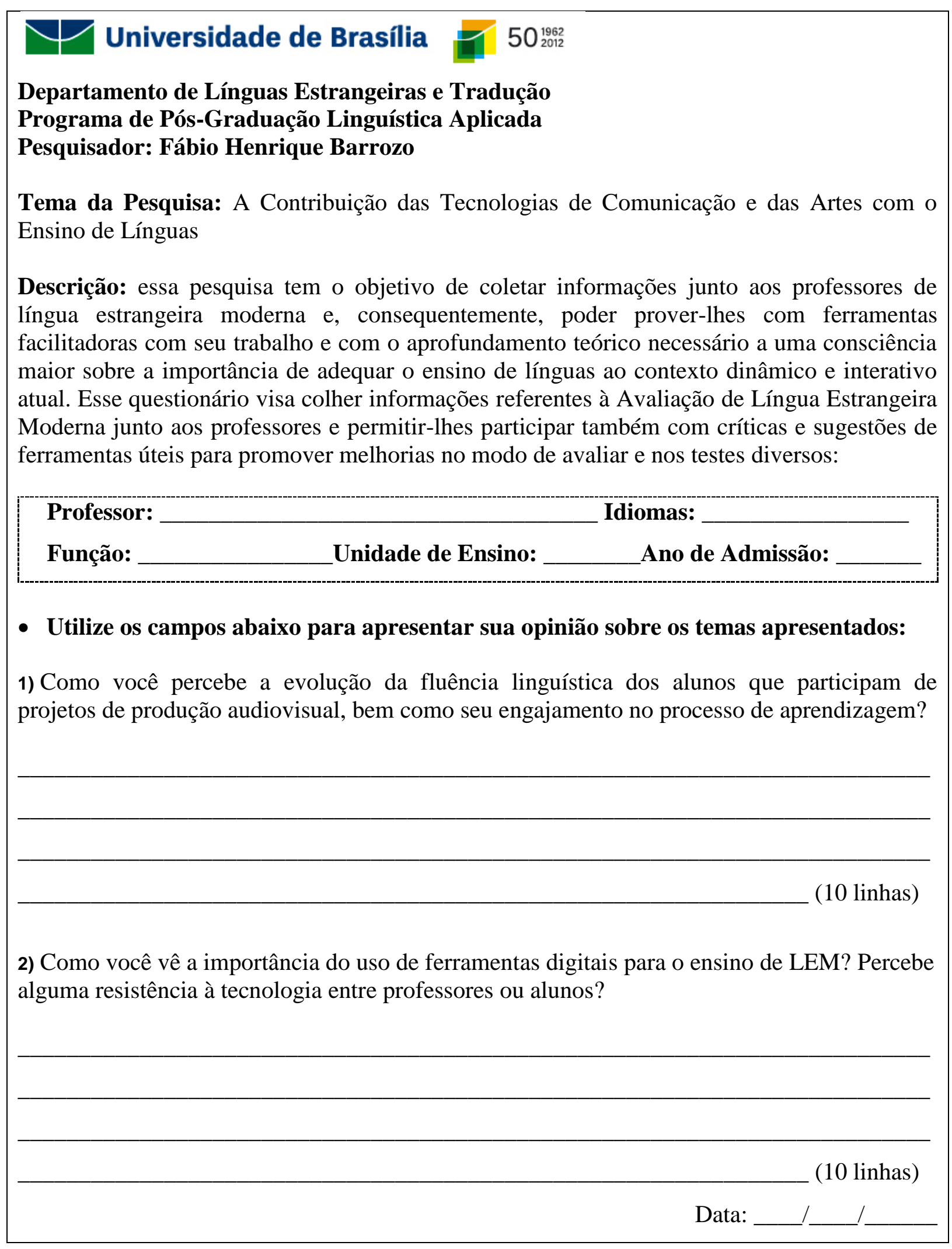

